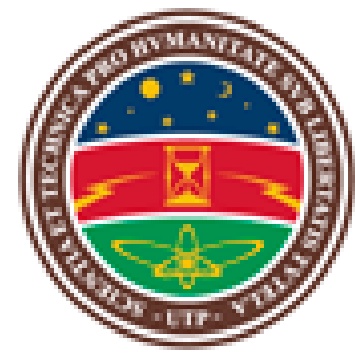

\title{
El sujeto en crisis en la narrativa de Fernando Cruz Kronfly
}

Jhon Walter Torres Meza 


\title{
Universidad Tecnológica de Pereira \\ Facultad de Bellas Artes y Humanidades
}

Maestría en Literatura

\section{El sujeto en crisis en la literatura de Fernando Cruz Kronfly}

\author{
Jhon Walter Torres Meza \\ Trabajo de grado presentado como requisito para optar al título de \\ Magíster en Literatura
}

Director

César Valencia Solanilla 


\section{Resumen}

En la presente investigación se planteó la categoría del sujeto en crisis en la narrativa del escritor vallecaucano: Fernando Cruz Kronfly. Se tomó como referencia la teoría del ser ahí descrita por el filósofo alemán Martin Heidegger en: El ser y el tiempo (1993), para describir la existencia del sujeto que evade la realidad. Postulamos que en las novelas de Cruz Kronfly: La obra del sueño (1984), La ceniza del Libertador (1987) y La caravana de Gardel (1999) el personaje principal no tiene una conciencia de sí mismo, su Yo escapa al presente y se refugia en la memoria.

Describimos que la memoria y el espacio son vitales en la categoría del sujeto en crisis. La memoria porque crea un espacio simbólico con imágenes pasadas donde el sujeto en crisis evade la realidad y eufemiza sus calamidades. Mostramos que en las novelas de Cruz Kronfly este elemento es vital pues crea el espacio del sujeto en crisis y rompe con la linealidad del tiempo. Además los personajes principales realizan un viaje que culminará en la muerte. Esto demuestra que el sujeto en crisis quiere escapar de la melancolía y la existencia que lo agobia.

Por último se mostró el artificio literario en Cruz Kronfly para observar e interpretar las distintas vertientes que desembocan en el discurso novelístico del autor vallecaucano como: historia y ficción, la ensoñación y la mezcla entre el pensamiento ensayístico de Cruz Kronfly y la visión de mundo del narrador.

\section{Palabras claves}

Modernidad, sujeto en crisis, ser ahí, memoria, régimen diurno, régimen nocturno, espacio, viaje, ficción-histórica, artificio, narrador, personaje, autor. 


\section{Agradecimientos}

A mis padres Ancízar Torres y Janeth Meza por no creer en imposibles. Al misterio de la literatura que me ha seducido en tantos años. A mi director de tesis, César Valencia, por su tiempo y palabras de luz. 


\section{Contenido}

Introducción;Error! Marcador no definido.

Un escritor atemporal;Error! Marcador no definido.

1. El sujeto en crisis en la narrativa de Fernando Cruz Kronfly ¡Error! Marcador no definido.

1.1 La crisis del sujetoiError! Marcador no definido.

1.2 El sujeto en crisisjError! Marcador no definido.

2. La caída y la memoria del sujeto en crisis;Error! Marcador no definido.

2.1 La caída del sujeto en crisisiError! Marcador no definido.

2.2 La memoria, el escape del sujeto en crisisiError! Marcador no definido.

3. El viaje hacia la muerte del sujeto en crisis y el agua de Caronte ¿Error! Marcador no definido.

3.1 El viaje hacia la muertejError! Marcador no definido.

3.2 El agua de la melancolíajError! Marcador no definido.

4. Artificio literario en Fernando Cruz Kronfly;Error! Marcador no definido. 4.1 La en soñación como recurso narrativo en La obra del sueñoiError! Marcador no definido.

4.2 Ficción-histórica en La ceniza del LibertadoriError! Marcador no definido.

4.3 Las voces del autor, narrador y personaje como artificios literarios en La caravana de GardeliError! Marcador no definido.

5. Conclusión¡Error! Marcador no definido.

Bibliografía;Error! Marcador no definido. 


\section{Introducción}

Lo perdurable es la obra de los poetas

Hölderlin.

\section{Un escritor atemporal}

El mundo vertiginoso del marketing y del consumo devora a algunos escritores contemporáneos. El oficio de escribir en Latinoamérica a mediados del siglo XX tuvo grandes momentos. Autores como Vargas Llosa en el Perú, Pablo Neruda en Chile, Julio Cortázar en la Argentina, García Márquez en Colombia, entre otros, plantearon una estética literaria que refractaba al hombre latinoamericano y su visión de mundo. En el postboom, los nuevos escritores exploraron la ciudad y el mundo urbano. Para poner un ejemplo mencionemos a Ricardo Piglia, estudioso de la literatura urbana de Roberto Arlt, en el autor argentino la ciudad es un tema recurrente, su novela Plata quemada (1997) muestra el crimen organizado y la figura del hampa como protagonista. En diferentes autores colombianos la estética literaria, después y bajo la sombra del gran auge de García Márquez y el realismo mágico como estilo literario, exploró diferentes facetas. Se podría decir de manera general que la ciudad, el conflicto social, la vorágine del hombre moderno enfrentado al mundo de su tiempo, la unión entre periodismo, literatura e historia, es un artificio y tema recurrente en la actual literatura colombiana ${ }^{1}$. No podemos definir de manera absoluta las características de una novela contemporánea, ya que siguiendo la tesis de Carlos Fuentes en Geografía de la novela (1995), esta se actualiza constantemente, no existe una última definición de lo que es una novela. Sin embargo, en el presente, el papel de la literatura colombiana se ha devaluado. Algunas novelas narcopolíticas, de sicarios y

1 Nos abstenemos de mencionar nombres de novelistas colombianos contemporáneos, pues el objetivo no es elaborar un canon de la actual literatura colombiana, pretendemos reflexionar sobre el hacer literario de los escritores de nuestro tiempo y nuestro país. 
prostitutas con siliconas, elaboradas con imágenes mediáticas, producto del consumo televisivo y la imagen comercial, sin metáforas y símiles, son las más leídas. En "Las sombras de la gloria" (2010), una entrevista realizada por Marcos Fabián Herrera Muñoz al escritor vallecaucano Fernando Cruz Kronfly, se menciona al respecto:

Lo que es realmente preocupante, aunque no signifique el fin del mundo, es que la literatura y la cultura terminaron por quedar atrapadas en las redes de esa cosa que se conoce como "marketing", en el sentido de que el cliente siempre tiene la razón y que es necesario escribir para él, lo que él quiere que le escriban en medio de su medianía. De esta manera, las casas editoriales terminaron por tratar las obras literarias como si fueran calcetines o jabones.

La cita describe el consumismo literario del mercado. Algunos escritores han perdido la capacidad de reflexionar sobre su tiempo, de indagar sobre las complejidades humanas, en su lugar ha quedado el entretenimiento vacuo. El sociólogo Zygmunt Bauman, en Modernidad líquida (2002), encuentra el quid del asunto al reflexionar sobre la modernidad y posmodernidad: "Tal como argumenté en Life in fragments (Polity Pres, 1996), la sociedad posmoderna considera a sus miembros primordialmente en calidad de consumidores, no de productores. Esa diferencia es esencial” (82). La diferencia que encuentra Bauman es fundamental: en la modernidad el hombre originaba y fabricaba el producto, en la posmodernidad solo lo consume. Esto sucede con algunos autores colombianos actuales, están sumergidos en la máquina del mercado, escriben lo que se vende, van a la vanguardia con las novelas televisivas que no ahondan en las palabras poéticas, en las metáforas que nos revelan simbólicamente el misterio del lenguaje. En el ensayo "La última generación de escritores" del libro Amapolas al vapor (1996) Cruz Kronfly señala lo siguiente:

Pues se ha incurrido en sus novelas y cuentos que, en el fondo, no son sino eso: "quiuvo hermano, soda, barájela despacio, zafa jirafa". Esta pseudo "lingüística", usada como fácil recurso de lo popular es con seguridad no sólo falsa sino facilista, reduccionista, efectista, repetida y sabe a fórmula barata $(71)$.

Y este falso recurso mencionado en la cita, lo emplean algunos escritores del consumo para crear obras que logran llegar a un grupo de lectores masivos que se alimentan de la 
televisión y de las imágenes mediáticas donde no existe ninguna consciencia sobre la función estética del lenguaje.

El escritor atemporal es aquel que reflexiona sobre lo humano y logra con un discurso elaborado, siguiendo la tesis de Milán Kundera en El arte de la novela (2009), decir aquello que solo la novela puede decir. Fernando Cruz Kronfly, escritor colombiano, nacido en Guadalajara de Buga, Valle del Cauca, en 1943, es uno de los pocos autores contemporáneos que se preocupa por crear una narrativa ontológica ${ }^{2}$, su lenguaje prolijo explora la poesía y la filosofía. Descendiente de una familia de emigrantes. Tuvo un padre colombiano y una madre árabe. A los catorce años su padre muere y hereda una biblioteca con libros clásicos que ayudaron a su formación intelectual. Creció rodeado de libros, en una diversidad cultural que quizá sirvió para que leyera con una mirada diferente la época de su tiempo. Su primer concurso literario lo gana a temprana edad. En Entrevista al Maestro Fernando Cruz Kronfly, Fabio Martínez, señala:

A los diez años Fernando ya había empezado a escribir poemas y uno de ellos le valió un primer premio: edición infantil del Quijote ilustrada por Doré. En 1966 obtiene un premio en un concurso de cuentos de la Casa Universitaria de Bogotá por un relato titulado "El sordomudo de Paoletta", y otro en 1968 en el Concurso Nacional de Cuentos por el relato "Por estos tiempos santos". Al año siguiente le tocó un primer premio a su cuento "El Café amanecido de los funerales de Candelario Rosales", y en 1972 queda finalista en el Concurso Latinoamericano patrocinado por la revista El Cuento, de México; el jurado lo constituía Juan Rulfo, Juan José Arreola y Edmundo Valadés (2015).

Es así que desde niño, el escritor vallecaucano siente una vocación intrínseca hacia el universo de la creación literaria.

Fernando Cruz Kronfly estudió Derecho y fue juez por algunos años en la ciudad de Cartago. Dictó seminarios de humanidades en la Universidad Santiago de Cali y la Universidad del Valle, de la cual se pensionó. No solo se ha interesado en la narrativa, en sus ensayos explora temas literarios y filosóficos. Entre sus libros se encuentran: $L a$

2 Empleamos la palabra ontológica en el sentido que Gilbert Durand, en Las estructuras antropológicas del imaginario (2004), la utiliza para referirse a la esencia simbólica de la imagen poética, cuya función es trascender el mismo campo del lenguaje. 
sombrilla planetaria (1994), texto de ensayos sobre modernidad y posmodernidad en la cultura. Hernando Urriago Benítez, en su investigación: La poética del ensayo en La sombrilla planetaria (2002), disertará sobre la capacidad del escritor vallecaucano como ensayista:

"FCK pertenece, como dijimos, a la gran tradición ensayística que nace en Michel de Montaigne, que alcanza enormes dimensiones con Voltaire y la Ilustración, y que, a salto de mata de tiempo, encuentra en América Latina esa mixtura cultural en el interior de la cual los problemas acerca del origen, la identidad, la coexistencia de temporalidades premodernas, modernas y postmodernas, el Ser americano, la historia, la novela, la política y la crisis social, entre otros, exigen una atenta actitud reflexiva de parte de los intelectuales del continente, en principio cronistas de su época pero luego cantores lógicos de los conflictos que plantea nuestra difícil pero atractiva condición cultural" (115).

Por tanto, como señala Urriago Benítez, Cruz Kronfly, además de ser un narrador consciente del lenguaje, es también un pensador de hondo calado. El estudioso de la literatura, César Valencia Solanilla, en el capítulo "La sombrilla planetaria de Fernando Cruz Kronfly" de su libro La escala invertida (1996) resalta la importancia del escritor vallecaucano en encontrar relaciones entre el discurso literario y la modernidad. Quizá por ello, la literatura no tiene solo la facultad de crear mundos ficcionales, también devela, como lo pensó Dostoievski creando un personaje psicológico como Raskolnikov, en Crimen y castigo, toda la complejidad y la crisis humana.

Amapolas al vapor (1996), es un compendio de ensayos sobre literatura. En su texto Cruz Kronfly realiza un estudio crítico a autores como: Borges, Isaac, Roberto Arlt, García Márquez, Freud, Rablais, entre otros. Es interesante señalar el amplio conocimiento sobre literatura y filosofía de Cruz Kronfly, tanto, que la Universidad del Valle en 1996, le otorgaría un Doctor Honoris Causa en Literatura.

La tierra que atardece, libro publicado en 1999, toma su nombre de un verso del poeta de Salzburgo Georg Trakl, y reflexiona sobre las dimensiones contemporáneas de la modernidad. Es necesario mencionar también el texto La derrota de la luz (2007) ensayos sobre modernidad, contemporaneidad y cultura. El escritor vallecaucano siempre ha tenido como referencia la época de su tiempo, se percibe su preocupación por la sociedad y el 
mundo actual donde se encuentra inmerso. Diferentes ensayos del autor han sido publicados en revistas y periódicos. Uno de los más conocidos académicamente es el texto "Desarrollo cultural, modernidad e identidad en Santiago de Cali" publicado en Visión de Cali 2036 (2009), en él, Cruz Kronfly postula cuatro sistemas de pensamiento que forman la estructura mental no solo de los habitantes vallecaucanos sino de todos los latinoamericanos, estos son: pensamiento mítico-hechicero, pensamiento teológicoreligioso, pensamiento lógico-racional y pensamiento científico, los cuales cohabitan y forman la estructura mental del hombre latinoamericano. Se observa entonces el interés del autor vallecaucano por interpretar su cultura.

La obra narrativa de Cruz Kronfly es vital para comprender nuevos estilos en la literatura colombiana, donde la poesía, la narrativa, la historia y la filosofía, se conjugan en un discurso elaborado llamado novela, en un símbolo que rinde tributo al lenguaje prolijo y a la manifestación artística de la palabra. La primera obra escrita de Fernando Cruz Kronfly fue La obra del sueño, sin embargo, se publicó en primera instancia Falleba-Cámara ardiente en 1980, con la cual el autor logra obtener el premio internacional de novela Villa de Bilbao, en España. Veinte años después la Universidad EAFIT vuelve a publicar la obra con algunas modificaciones del autor. El profesor Darío Henao, en una entrevista titulada: Un novelista del hondo abismo del oficio de escribir, le pregunta el motivo de los cambios, el escritor vallecaucano responde:

20 años después de publicada Falleba, la editorial de EAFIT se interesó por republicarla y yo coloco como condición someterla a una revisión. Pensé que iba a ser menor, al leerla de nuevo, me encontré que yo era otro y que por lo tanto revisarla significaría rescribirla, porque o me limitaba a ciertos aspectos formales o me atrevía a escribirla de nuevo, desde la perspectiva en la que yo ya estaba después de más de 20 años. Y opté por lo segundo. Desde luego la historia es la misma, pero disfruté inmensamente de este trabajo con ella, que me ocupó cerca de un año y confirmé a medida que trabajada que la literatura es lenguaje. Definitivamente la historia era la misma, los problemas eran los mismos y seguían siendo vigentes para mí, veinte años después; pero el modo de decirlo era otro, y ese modo de decirlo es lo que es la literatura (2012).

Lo anterior demuestra la entrega constante de Cruz Kronfly al oficio de escribir y reescribir, de volver sobre sus palabras en busca de sí mismo, como si allí se descubriera. En 1980, el escritor vallecaucano publica una antología de cuento titulada Las alabanzas y 
los acechos. Es relevante señalar que este libro obtuvo un reconocimiento nacional convocado por la revista Vivencias de Cali, y el cuento Las enmiendas como curaciones en el prójimo fue finalista en el concurso latinoamericano "El cuento de México". Muchos periódicos, tesis en investigación literaria y revistas especializadas del país han resaltado la importancia de Cruz Kronfly en la cuentística colombiana. Harold Kremer, estudioso de la literatura vallecaucana, en el libro Antología del cuento vallecaucano (1992) señala algunas de las características de su escritura: "Los personajes de sus cuentos se mueven en pueblos tristes y sin esperanzas, en barrios suspendidos en el tiempo, en casonas invadidas por la soledad. Es un autor que recurre constantemente al monólogo para mostrarnos las voces de la locura, del amor, de la muerte, del desencanto" (77). En 1984 La Editorial Oveja Negra publica su novela La obra del sueño, la cual abordaremos posteriormente para interpretar el símbolo del viaje y de la muerte; tres años más tarde, 1987, Cruz Kronfly da a conocer La ceniza del libertador en la que relata los últimos días del general Simón Bolívar y su viaje en una embarcación por el río Magdalena. La ceremonia de la soledad en 1992 muestra la complejidad de la vida a través de algunos personajes, entre ellos uno principal: Graciana Lorenza, quien fracasa en el amor y su ceremonia es la soledad. El relato La última noche de Antonio Ricaurte aparece en 1997, publicado en la Editorial Pontificia Bolivariana con una extensión de cincuenta páginas. El texto cuenta la historia de Antonio Ricaurte, un personaje histórico de la colonia. En la actualidad, en el Valle del Cauca, un corregimiento del municipio de Bolívar lleva su nombre. El embarcadero de los incurables se publica en 1998 por la editorial Norma. Álvaro Pineda Botero en el libro Estudios críticos sobre la novela colombiana (2005) realiza un análisis detallado sobre la obra, donde resalta del escritor vallecaucano el esmerado empleo del lenguaje estético y la capacidad para refractar por medio de sus personajes la sociedad del momento. En este mismo año, 1998, se publica una novela magistral: La caravana de Gardel, la cual narra el viaje a mula que tuvo el cadáver de Gardel por Colombia a través del recuerdo de uno de los arrieros llamado Arturo Rendón que transportó su cuerpo. Nuestro escritor también ha publicado poesía, prueba de ello es su libro Abendland (2002). En entrevista con Darío Henao, el escritor menciona: 
En Abendland lo que hay es una visión del mundo, ya que es una representación del mundo que desde luego está muy ligada a la infancia y a lo que sucede en los momentos de la fundación subjetiva, porque todos nosotros somos fundados en los primeros años y yo crecí en un ambiente laico por el lado de mi padre, no así por el lado de mi madre; pero de todas maneras ella tampoco era una creyente así a raja tabla, sus ideas religiosas eran unas ideas bastante liberales y no me explico el porqué, nunca he podido entenderlo, siendo árabe era así: tan liberal y lo fueron y lo son todos mis tíos (2012).

Fernando Cruz Kronfly publica La vida secreta de los perros infieles (2011) en la Editorial española Mirada Malva. En esta obra, que tiene un aire de humor y melancolía, reaparecen algunos de los personajes de Falleba y El embarcadero de los incurables: Uldarico, Pánfilo, Mariana Valentina, Manzana Tucupita, quienes protagonizan una historia de infidelidad, viven la complejidad de la existencia y gozan del misterio del engaño y el amor que los vuelve prisioneros a sus cuerpos. La última novela de Cruz Kronfly, Destierro, publicada en 2012 por la Editorial Sílaba, narra la vida de un inmigrante árabe. Fabio Martínez interroga al autor por su origen sirio, su descendencia y su influencia en la obra:

Si debiera caracterizar mis orígenes tendría que reconocer que soy bicultural. La presencia del mundo árabe, por el costado materno, es muy fuerte. Mi padre, colombiano, resultó colonizado por la tradición alimentaria árabe y, en general, mediterránea. Siria es hoy un país de muchos conflictos interiores. Ahora mismo la ciudad de origen de mi familia materna, Homs, está totalmente despedazada, bombardeada. Siria es el país del mundo con más desplazados. Le sigue Colombia. Mira qué macabra coincidencia (2015).

Y más adelante Fernando Cruz Kronfly matiza la relación de su origen sirio con la obra:

Mi padre tulueño era un hombre realmente culto. Librepensador ilustrado. Leía a mamá capítulos de Víctor Hugo, Balzac, Gogol, Gorki, Dostoievski. Se sentaba a leer a la sombra de las palmas de dátiles a comer quibbe y beber coñac francés. La biculturalidad me asediaba por todas partes. De esta experiencia cotidiana nació en mí el espíritu del desterrado, en términos de Todorov. Desde que nací fui un desterrado que no era ni de aquí ni de allá. Eso es lo que cuento en mi última novela, que es el relato de un doble destierro.

Por tanto, Destierro, nace de una vivencia personal. Lo genotextual, que según Edmon Cros en Ideología y genética textual (1992), son las vivencias significativas del autor que dan origen a la obra, logra develarse en la novela si se indaga por las raíces sirias de Cruz Kronfly. 
Fernando Cruz Kronfly es uno de los mayores representantes de la literatura urbana y citadina. Los estudiosos de la literatura vallecaucana: Fabio Martínez y Hernando Urriago en su libro Cali-grafías La ciudad literaria (2008) incluyen al autor vallecaucano como uno de los grandes representantes de la literatura no solo de Cali sino también de Colombia.

Fernando Cruz Kronfly es un escritor atemporal. El autor vallecaucano de manera prolija explora la poesía y la filosofía. No cae en imágenes mediáticas ni en un lenguaje vacuo, sus metáforas y símiles indagan por la complejidad humana. En La obra del sueño utiliza diálogos que refractan no solo la visión de mundo de los personajes frente a su realidad, sino el pensamiento posmoderno. Observemos: "Pertenezco a la gran estirpe de los pensadores tristes para quienes el mundo a duras penas tiene la consistencia de la mierda, tal como en cierta oportunidad lo alcanzó a insinuar mi inigualable maestro Jean Paul Sartre" (1980:20). Lo anterior es una meditación de Leopoldo, uno de los personajes principales de la obra, se puede comprender el universo filosófico de Cruz Kronfly, que por medio de Leopoldo expone la idea existencialista de El ser y la nada, que en Sartre es vital para plantear la crisis existencial. En La ceniza del Libertador se conjugan de forma magistral la poesía y la prosa. Cruz Kronfly introduce en la novela poemas en verso libre que ilustran los pensamientos y visiones del libertador Simón Bolívar:

\footnotetext{
Blancos muros lejanos en el ojo donde la memoria sustituye a la imagen

Secantes intervenidos por el secreto que campea en la leche de cal

Techos de barro, musgo encendido en las gracias del viento

De golondrinas cacas

Aquel chorro sangriento de los murciélagos locos en los mangos de almíbar

La lejanía constante, siempre la lejanía de la ventana que nunca llegó

Toda la cal dilatando esa claridad

El farol apagado en el borrón del tiempo [...] (1987:136).
}

Es así que el escritor vallecaucano, atemporal porque no cae en el libertinaje de las imágenes mediáticas de algunos autores contemporáneos, logra crear una literatura que 
entreteje símbolos que se develan y se interpretan mediante un lenguaje esmerado y cuidadoso.

En la presente investigación se pretende plantear el sujeto en crisis en la narrativa de Fernando Cruz Kronfly. Algunos de sus personajes tienen una característica que los identifica: son sujetos en crisis que evaden la realidad, que escapan al presente y se refugian en la memoria. Se busca no sólo mostrar una característica de sus personajes, sino la evolución de su narrativa, los elementos simbólicos, oníricos, y meta-ficcionales, que forman su obra literaria. Las novelas escogidas para nuestro estudio: La obra del sueño (1984), La ceniza del libertador (1987) y La caravana de Gardel (1998) muestran claramente el sujeto en crisis en la posmodernidad o contemporaneidad. La memoria y el espacio juegan un rol fundamental para comprender y ahondar en la psique misma del sujeto que pretendemos estudiar, ya que este no existe en el presente, sino en la memoria, en el recuerdo y en el espacio que eufemiza el tiempo. Es necesario mencionar que para explicar los conceptos de espacio, memoria y tiempo, nos basaremos en Gilbert Durand, teórico francés, perteneciente a la escuela de Eranos, que postula en su obra capital: Las estructuras antropológicas de lo imaginario (2004), que la memoria crea un espacio donde el tiempo se eufemiza y el sujeto se libera de la carga existencial.

Definiremos el sujeto en crisis desde la filosofía existencialista de Martín Heidegger. Pretendemos plantear que la memoria es una particularidad propia del sujeto en la obra de Cruz Kronfly. Con base en la obra del teórico francés Gilbert Durand, Las estructuras antropológicas de lo imaginario (2004) interpretaremos el espacio, la manera de exorcizar el tiempo y el significado del viaje y la muerte, que son los temas principales de nuestros capítulos. Es necesario mencionar que realizaremos interpretaciones hermenéuticas y algunas estructurales y polifónicas, siguiendo la idea de Bajtin en Teoría y estética de la novela (1989), que nos lleven a tener una visión amplia sobre el artificio de la obra, como en el caso de La ceniza del libertador (1987), donde la historia y la ficción se entretejen para formar una nueva recepción de la obra. 
Se tomará en préstamo el ser ahí planteado por Heidegger en El ser y el tiempo (1993), donde pareciera que el sujeto no viene cargado de la razón instrumental cartesiana y se desvaneciera, no se puede definir y cae en las imágenes de tiempos olvidados. En las novelas de Fernando Cruz Kronfly, la memoria, que según Durand, eufemiza las calamidades y la crisis de la existencia juega un rol fundamental. La crisis, como lo veremos a posteriori, es la angustia del ser humano enfrentado al mundo de su tiempo. Se describirá la categoría de ego experimental, planteada por Kundera, en El arte de la novela, porque refracta también la crisis, el vacío de la existencia planteado en la novela. De igual forma veremos algunos textos teóricos y literarios para tener una imagen general del sujeto en crisis y su refracción en la historia narrativa.

Es necesario mencionar que involucraremos en la presente investigación diversos autores, conceptos y obras, que generarán relaciones de sentido con nuestra tesis principal: El sujeto en crisis. Los temas a desarrollar en nuestros capítulos de investigación serán los siguientes: El espacio y la memoria, la crisis existencial, la muerte y el viaje del sujeto en crisis. Estos temas girarán en torno a las imágenes poéticas del escritor Fernando Cruz Kronfly, ya que siguiendo uno de los planteamientos de Gaston Bachelard en La poética del espacio (2003), se debe seguir al poeta hasta la profundidad de las imágenes. Y es allí, en las imágenes simbólicas donde exploraremos los sentidos emergentes de la obra. 


\title{
1. El sujeto en crisis en la narrativa de Fernando Cruz Kronfly
}

\begin{abstract}
¿De qué nos sirve, por fin, una larga vida, si es tan miserable, tan pobre en alegrías y rica en sufrimientos, que sólo podemos saludar a la muerte como feliz liberación?

Sigmund Freud. El malestar en la cultura.
\end{abstract}

\subsection{La crisis del sujeto}

Para plantear el sujeto en crisis en la narrativa del escritor vallecaucano Fernando Cruz Kronfly, es necesario reflexionar sobre lo que genera la crisis, ya que la sociedad y la cultura influyen constantemente en la caracterización del individuo. El objetivo entonces de este apartado es tratar de describir la época y la naturaleza cultural que genera la crisis del sujeto.

Fernando Cruz Kronfly en La sombrilla planetaria (1994:12) postula que la modernidad comienza con el renacimiento o a partir del momento en que el oscurantismo medieval a finales del siglo XV se debilita. Queremos indicar que no pretendemos ser tajantes con las fechas en que empieza dicho fenómeno o concepción de mundo, ya que puede variar según la intención o interpretación del autor. En el Medioevo Dios era el centro del universo, luego, como señala Ernst Cassirer en Antropología filosófica (1996), la teoría heliocéntrica

de Copérnico lo desplaza y el ser humano emprende una revolución mental que centrará sus bases en la lógica instrumental y la razón. Inventos tan importantes como la imprenta de Johan Gutemberg (1398-1468), generarán un cambió interpretativo de los textos que trasladan la lectura colectiva a la individual, surgen entonces sujetos autónomos e independientes. Con pensadores como Galileo Galilei (1564-1642) en la astronomía, Descartes (1596-1650) en filosofía, Blaise Pascal (1623-1662) en el campo matemático, William Shakespeare y posteriormente Cervantes en literatura, entre otros pensadores y artistas relevantes, se iniciaría con claridad un nuevo periodo en la historia humana. Es importante señalar que el sociólogo alemán Max Weber, en su libro La ética protestante y 
el "espíritu" del capitalismo, menciona el papel que tuvo el protestantismo con sus máximos representantes: Lutero y Calvino, para el desarrollo de la modernidad en occidente. El protestantismo, a diferencia del cristianismo medieval, logra desprenderse del clero y crea una conciencia monetaria que sumergirá al individuo en la búsqueda de un bien particular. Según Weber el protestantismo genera una organización racional del capital, donde el trabajo formal estimula a las personas a nuevas dimensiones de su entorno social y económico. El sociólogo menciona la relación entre el dinero y el rol que desempeña el hombre en la modernidad: "El hombre queda referido a ese ganar dinero como el objetivo de su vida, no es la ganancia la que queda referida al hombre como un medio para la satisfacción de sus necesidades materiales" (2012: 88). Lo anterior muestra claramente lo importante del dinero y la economía para el hombre moderno, en palabras de Weber sería el espíritu capitalista, que es la consciencia y la mentalidad económica del individuo, que además de desprenderse de Dios, tiene la visión de enriquecerse.

Es necesario hacer claridad en los conceptos de modernidad, modernismo y modernización. Entendemos la modernidad, siguiendo la idea de Marshall Berman en Todo lo sólido se desvanece en el aire (1991), un cambio de mentalidad que empieza desde el renacimiento. El modernismo se desarrolla principalmente en el arte y la literatura, Berman menciona que en el siglo XIX y a mediados del XX, el modernismo alcanza su máxima expresión. Modernización es un adelanto de la técnica que se ve reflejada en la tecnología, en la industria y en el sistema capital. Es así que el inicio de la modernidad trae consigo una visión monetaria, económica e industrial que generan nuevas perspectivas para el hombre de la época. Al hablar de posmodernidad o lo que ha pasado después de la modernidad, nos referiremos específicamente a la mitad del siglo XX o siglo XXI.

La modernidad, después del Medioevo, siembra unas estructuras firmes en la concepción del capital, el trabajo y el humanismo. En los siglos posteriores, con el adelanto de la tecnología y la ciencia, la modernización y la racionalidad humana desembocan en dos guerras mundiales. La primera de 1914 a 1918, la segunda de 1939 a 1945, donde las grandes potencias mundiales ponen el adelanto tecnológico y el triunfo de la razón al servicio de la destrucción. Recordemos las dos bombas atómicas que lanzó Estados Unidos 
contra Japón y destruyó por completo las ciudades de Hiroshima y Nagasaki. El sociólogo John Gray en El silencio de los animales. Sobre el progreso y otros mitos modernos menciona:

La ciencia y la idea de progreso pueden parecer unidas, pero el resultado final del progreso en la ciencia es mostrar la imposibilidad del progreso en la civilización. La ciencia es un disolvente de la ilusión y, entre esas ilusiones que disuelve, se encuentran las ilusiones del humanismo. El conocimiento humano aumenta, pero la irracionalidad humana se mantiene igual. Se puede considerar a la investigación científica como la razón hecha cuerpo, pero lo que demuestra esa investigación es que los seres humanos no son animales racionales. El hecho de que los humanistas se nieguen a aceptar la demostración es la prueba misma de que es cierta (2013:70).

Lo anterior demuestra que el progreso de la civilización es una falacia. Por tanto, la modernidad, que en su proyecto ilustrado sacó al hombre del oscurantismo medieval, parece ser que no ha logrado el ideal de perfección e inclusión que tuvo en sus comienzos. Es necesario mencionar que la modernización ha ayudado al hombre en su labor cotidiana, la tecnología nos ha permitido acortar distancias y crear mundos virtuales, sin embargo, la historia ha demostrado que la idea de progreso hacia una sociedad humanista, es una utopía. Zygmunt Bauman en Modernidad líquida (2000) demuestra como el fenómeno del capitalismo, de la industria y de la venta, absorbe la vida del individuo, al punto que utiliza la metáfora de la liquidez para referirse a la contemporaneidad. El proyecto de la modernidad, que trajo consigo la lógica matemática y el pensamiento aristotélico, hizo desprender al hombre de sus creencias mágicas. Ahora, cuando el proyecto moderno ha fracasado, el único consuelo para el individuo es comprar y trabajar, para seguir en un círculo de consumo donde la sociedad lo esclaviza. Si las personas compran un objeto hoy, mañana ya no lo querrán, pues los mismos fabricantes del primer artículo ya han inventado otro mejor para que el usuario sienta necesidad de adquirirlo. Bauman menciona a los sociólogos Weber y a Carlyle para reflexionar sobre el rol del dinero y el consumo en la posmodernidad:

"Derretir los sólidos" significaba, primordialmente, desprenderse de las obligaciones "irrelevantes que se interponían en el camino de un cálculo racional de los efectos; tal como lo expresara Max Weber, liberar la iniciativa comercial de los grilletes de las obligaciones domésticas y de la densa trama de los deberes éticos; o, según Thomas Carlyle, de todos los vínculos que condicionan la reciprocidad humana y la mutua responsabilidad, conservar tan sólo el "nexo del dinero" (10). 
La cita explica que en la posmodernidad el proyecto sólido hacia una sociedad humana y colectiva, con principios éticos, se desvanece. El dinero y el consumo terminan siendo el anhelo del hombre actual. Bauman también reflexiona sobre la emancipación. El concepto de individuo cambia, ya no es aquel que piensa por sí mismo y tiene una visión crítica del sistema, está atado al consumo, no reflexiona sobre el entorno, pues vive para ganar un sueldo y obedecer órdenes. La individualización contemporánea consiste en que cada cual busca un bien particular y lo privado gana más poder, la colectividad y el ciudadano se disuelven, por tanto, el sujeto se siente cada vez más solo. Al autor plantea: "Resumiendo: la otra cara de la individualización parece ser la corrosión y la lenta desintegración de la ciudadanía" (42). Es así que la individualización que depende solo del sistema de consumo masivo termina por abolir la colectividad ciudadana, por tanto, la humanidad y el ideal democrático no avanza. Se crea entonces alrededor del sujeto una crisis, que es el producto del proyecto moderno.

Sigmund Freud, fundador del psicoanálisis, en El malestar en la cultura (2006) plantea que el ser humano es un ser destructivo por naturaleza, si realiza un acto benevolente es porque la cultura se lo exige mediante la ética. El psicoanalista realiza un estudio sobre las causas que inhiben el deseo sexual y postula que el ser humano psíquicamente no es feliz, la cultura es la causante de su infelicidad, ya que además de cohibir sus deseos le impone un sistema social y unas normas de conducta. Para nuestro estudio Freud es vital pues nos muestra una dimensión compleja del ser humano y cómo la cultura, mediante modelos sistémicos, crea una pesadumbre en el sujeto. El autor nos dice: "Tal como nos ha sido impuesta, la vida nos resulta demasiado pesada, nos depara excesivos sufrimientos, decepciones, empresas imposibles" (20). En la cita se percibe un malestar y una sensación de fracaso. Es relevante señalar que para Freud el hombre no puede alcanzar la felicidad:

Agrégase a esto el influjo de cierta decepción. En el curso de las últimas generaciones la humanidad ha realizado extraordinarios progresos en las ciencias naturales y en su aplicación técnica, afianzando en medida su inconcebible dominio sobre la naturaleza. No enunciaremos, por conocidos de todos, los pormenores de estos adelantos. El hombre se enorgullece con razón de tales conquistas, pero comienza a sospechar que este recién adquirido dominio del espacio y del tiempo, esta sujeción de las fuerzas naturales, cumplimiento de un anhelo multimilenario, no ha elevado la satisfacción placentera que exige de la vida, no le ha hecho, en su sentir, más feliz (31). 
Es así que a pesar del avance de las ciencias y la técnica, de las distintas revoluciones independentistas que trajeron consigo el proyecto moderno, no se ha logrado brindar un ideal de felicidad. Existe, según Freud, un malestar en la cultura que impone al sujeto ciertas metas, comportamientos y sacrificios.

La crisis del sujeto se genera debido al fracaso del progreso humanístico de la modernidad. Hemos avanzado en todo, menos en hacernos más humanos. El siglo XX ha demostrado que la racionalidad y la tecnología han servido para destruirnos mutuamente. La industria y el sistema capital producen nuevos esclavos. Quisimos mostrar que la modernidad en sus inicios, con un sistema monetario, sacó al hombre medieval del oscurantismo, luego esta cayó en una utopía. El mismo Cruz Kronfly en su libro de ensayo La sombrilla planetaria plantea que el relato de la modernidad que prometió un futuro mejor ya no es creíble, hay un desencanto y un sin sabor de aquel proyecto ilustrado que pretendió brindar al ser humano una sociedad más justa y equitativa. Al respecto refiere:

Los que han entrado en crisis son quizás los mitos o metarrelatos que se contruyeron en torno de ellos, la fe a ciegas en sus virtudes y posibilidades, lo que ha quedado en evidencia es la mentira que todo ello escondía: La historia como supra-sujeto, como la otorgadora de todo sentido, como gran tribunal que sustituyó al tribunal de Dios; el progreso como mito de un cada vez mayor perfeccionamiento, la razón como instrumento de eliminación y control de la barbarie y de la inhumanidad (1994:34).

El autor hace énfasis en que el relato moderno se encuentra desgastado.

En la modernidad surgen, según Bauman, seres líquidos, atados al consumo y la mediatez. Con Freud analizamos la infelicidad y el malestar en la cultura que crea la crisis del sujeto. Observaremos que los personajes del novelista vallecaucano Fernando Cruz Kronfly se encuentran inmersos en una crisis, producto del sistema social y también, siguiendo la idea de Freud, psíquicamente infelices, pues la cultura los cohíbe, ya no creen en el relato del progreso moderno. Pasemos entonces, después de haber intentado mostrar que en la posmodernidad o contemporaneidad ya no es posible creer en la felicidad ni en un tiempo mejor, a interpretar las características del sujeto en crisis y las imágenes simbólicas que se 
encuentran presentes en la narrativa de Cruz Kronfly, un escritor que escapa a la metáfora de la liquidez ${ }^{3}$.

\subsection{El sujeto en crisis}

Antes de abarcar el sujeto en crisis en la literatura de Fernando Cruz Kronfly, es necesario realizar un seguimiento del concepto para lograr plantear nuestra conjetura ${ }^{4}$. Desde la antigua Grecia, el sujeto se construye con el otro. Con aquellos que habita se transforma y se individualiza. Siempre está sujetado a algo. Jean Pierre Vernant, estudioso de la cultura griega, en El individuo, la muerte y el amor en la antigua Grecia, señala: "El sujeto no conforma un mundo interior cerrado, dentro del cual hubiera de penetrar con el fin de reencontrarse o más bien de descubrirse. El sujeto es extroversión” (2001:216). En esa extroversión que menciona el autor, el sujeto se construye, por tanto, para reconocerse se necesita una relación exterior con el otro. Si bien la categoría de sujeto es muy antigua, es con la novela donde se genera la crisis. Aunque Harold Bloom, en Shakespeare: la invención de lo humano, menciona que Shakespeare crea el individuo y lo exalta por encima de Cervantes. Es sólo con la novela donde el hombre se enfrenta a la cotidianidad de la existencia. Bloom en su recorrido por el canon occidental plantea: "He escrito en otro lugar que Shakespeare no sólo es por sí mismo el canon occidental; se ha convertido en el canon universal, tal vez el único que puede sobrevivir al actual envilecimiento de nuestras instituciones de enseñanza aquí y en el extranjero" (2001:39). En su estudio, el teórico se centra en los diálogos de Hamlet para postular el surgimiento del carácter. Aunque su tesis

3 Es importante referir que no pretendemos mencionar que la crisis del sujeto se presenta debido a la utopía del proyecto de la modernidad en Colombia o Latinoamérica. Nuestro objetivo es mostrar como en el campo de la literatura, Fernando Cruz Kronfly refracta en sus personajes el sentimiento de fracaso del relato moderno.

$4 \quad$ Es relevante mencionar que aunque tomaremos en préstamo la categoría del ser ahí del filósofo alemán Martín Heidegger, nuestro enfoque del sujeto en crisis es interpretar cómo se devela en el discurso literario. 
es válida, en la novela el sujeto se desmitifica y pierde el áurea que quizá en la tragedia conservaba. Cervantes es fundamental para entender el surgimiento del sujeto en crisis, porque Don quijote de la Mancha se enfrenta a un mundo donde la vida diaria lo marginaliza y debe luchar, no tanto por cumplir sus hazañas, si no, por combatir el sistema de su época que tiene un desencanto del Medioevo.

En la novela psicológica de Dostoievski (siglo XIX), Crimen y castigo (1967), el sujeto en crisis lo encarna Raskolnikov. Este personaje intelectual enfrenta un mundo que lo marginaliza por su pobreza y condición social. Aunque Raskolnikov asesina y roba a una mujer usurera que lo explota, no puede escapar de la sociedad que lo consume. El sujeto en crisis se ve sometido a la dificultad de la existencia y debe obtener dinero para sobrevivir.

En la literatura del siglo XX, encontramos de manera más desarrollada el sujeto en crisis que pretendemos plantear. En los párrafos anteriores mencionamos que la novela genera el nacimiento de la crisis del personaje, lo cual quiere decir que la modernidad literaria empieza a mostrar el conflicto existencial. En la evolución narrativa de la novela, el sujeto en crisis adquiere un matiz marcado. El autor de la obra enfrenta al personaje a un mundo que no le ofrece nada. El problema existencial se torna complejo, pues el escritor intenta refractar el fracaso de la modernidad en su obra. Es necesario precisar que al mencionar el fracaso de la modernidad, nos referimos a que la idea del relato del progreso humanístico ha sido una utopía, pues la tecnología y el avance científico no han ayudado para que el hombre sea más tolerante y comprensivo, tal como lo mostramos en la introducción del presente trabajo.

Milán Kundera, en El arte de la novela (2010), para hablar sobre la complejidad de la existencia en sus personajes, menciona la categoría de ego experimental, que es el vértigo y el vacío del ser humano contemporáneo que se refracta en sus obras. En La insoportable levedad del ser, una de sus novelas cumbres, Kundera crea esta característica en sus personajes, que para nosotros marca claramente el sujeto en crisis y el concepto de ego experimental. Al respecto el autor menciona en una entrevista realizada: "El vértigo es una 
de las claves para comprender a Teresa. No es la clave para comprendernos a usted o a mí. Sin embargo, usted y yo conocemos esta especie de vértigo al menos como nuestra posibilidad, una de las posibilidades de la existencia” (1994: 42). Es así que la novela, plantea Kundera, muestra ese vacío e insipidez del individuo, al que llama ego experimental.

En la literatura colombiana, para ejemplificar el sujeto en crisis, queremos mencionar un cuento emblemático del escritor José Félix Fuenmayor: La muerte en la calle (1967). En este cuento, el personaje principal es un mendigo que recuerda la muerte de su madre y cómo su tío lo abandonó con un cajón de lustrar botas cuando era apenas un niño. El relato es importante porque muestra el pensamiento de un indigente, su marginalización en la sociedad. Además, el personaje principal no vive sino que recuerda, lo cual es una característica del sujeto en crisis que debe enfrentar la carga de la existencia.

Es necesario señalar, para nuestra indagación, algunos ensayos que dialogan desde distintos puntos de vista con nuestra investigación: "Cuestiones filosóficas de la literatura colombiana del siglo XX” en la revista Papel (2010) de Ronald Bermúdez, donde el autor realiza un seguimiento a algunas obras de literatura latinoamericana y colombiana que plantean la crisis existencial del personaje. Además, la autora Bernardita Llanos muestra en “El sujeto explosionado” publicado por la revista Literatura y lingüística (1997) cómo se manifiesta este sujeto en la escritora chilena Diamela Eltit. En las investigaciones encontramos también el trabajo de Edwin Alonso Bonilla Una lectura filosófica al personaje anómalo de la nueva narrativa colombiana (2010), que explora la dimensión del personaje y sus conflictos internos.

Para terminar nuestro recorrido y tener una visión panorámica sobre el sujeto en crisis, nos permitiremos mencionar a Robert Abirached, estudioso del teatro contemporáneo y dramaturgo francés, que postula en el texto La crisis de la representación: el personaje, el mundo y el yo, que el actor contemporáneo se olvida de lo real, del espacio, se libera del mundo y se desencarna como un hombre de la calle. El autor indica: "Vuelto a ser fantasma entre fantasmas, se reduciría así la palabra, la sola que puede hacerlo surgir en un juego 
inagotable de virtualidades sobre el escenario inmaterial del entendimiento, dejando que su lector sea dueño de suscitarlo a partir de las páginas de un libro” (2011:173). La palabra sobre un escenario inmaterial, será pues el espacio del sujeto en crisis que plantearemos a continuación.

El sujeto en crisis evade la realidad. No tiene una conciencia del momento que vive, escapa del presente y se refugia en la memoria ${ }^{5}$. No es un sujeto cartesiano, controlador y dominador, pareciera que se diluye y no se encuentra. La razón del Yo, característica de la modernidad inaugurada en filosofía por Descartes se desvanece. Juan Morán señala esta particularidad que pretendemos plantear. En su ensayo "Retorno al sujeto" del libro $L a$ filosofía política en perspectiva, muestra:

En cualquier caso, nadie dudaría hoy de que esa imagen de un sujeto plenamente consciente de sí mismo, fundante, soberano, dueño de sí mismo, de la naturaleza y de la historia ha sido definitivamente derrumbada. Aquella figura del sujeto, que de manera tan ritual como canónica solía ser identificada con el cogito cartesiano, se nos revela hoy día como ilusoria; o más bien, como una ilusión puramente metafísica (1998:20).

Nuestro sujeto en crisis sigue la línea descrita por Morán, no tiene una consciencia dominadora de sí mismo, el cogito ergo sum se diluye en la complejidad de la existencia.

El filósofo alemán Martin Heidegger, meditó sobre el problema del ser y la existencia del hombre. Desarrolló una corriente existencialista para plantear que el sujeto dominador cartesiano en realidad evade la conciencia, Heidegger derroca al sujeto racional de su superioridad. Morán lo explica con claridad:

Por de pronto, lo que me interesa destacar es que el violento ataque contra la metafísica cartesiana que recorre todo el quehacer intelectual de Heidegger -desde su temprana y más importante obra, Ser y tiempo, hasta sus escritos más tardíos como el que he venido aludiendo-, va dirigido fundamentalmente a destronar a este sujeto de su «soberanía». Lo que explica, en definitiva, que no pocos intérpretes de la modernidad hayan acabado cifrando e itinerario biográfico del sujeto moderno entre la partida de nacimiento cartesiana y el certificado de defunción heideggeriano (20).

5 Sobre el simbolismo de la memoria y el tiempo nos ocuparemos en el segundo capítulo de la presente investigación. 
Y es este sujeto que menciona la cita el que estudiaremos en nuestra investigación. Un Yo que escapa de sí mismo, que evade la realidad, donde la consciencia se desvanece y queda un aire de melancolía en la atmósfera literaria.

En El ser y el tiempo, obra fundacional del pensamiento heideggeriano, el filósofo empieza por definir una categoría fundamental: el ser ahí, que es una posibilidad de la existencia, es decir puede llegar hacer si se pregunta por la ontología de lo humano, ya que el ser, según Heidegger es una posibilidad. Al respecto menciona:

El "ser ahí" es un ente que no se limita a ponerse delante entre otros entes. Es, antes bien, un ente ónticamente señalado porque en su ser le va este su ser. A esta constitución del ser del "ser ahí" es inherente, pues, tener el "ser ahí", en su "ser relativamente a este su ser", una "relación de ser". Y esto a su vez quiere decir: el "ser ahí" se comprende en su ser, de un modo más o menos expreso (1993:22).

El ser ahí como un ente del ser, que interroga por su esencia, que necesita tener una relación, sin embargo no es definible. Se percibe entonces un sujeto disuelto, no dominador ni supremo dueño de su consciencia.

El sujeto en crisis que pretendemos plantear es también la posibilidad, siguiendo a Heidegger, del ser ahí. Un sujeto que escapa al presente, que evade la realidad que enfrenta. El filósofo alemán resalta con claridad la idea del ser: "Quizá el "ser ahí" diga, siempre que inmediatamente "dice de sí mismo", "soy yo", pero a la postre lo diga más alto que nunca justo cuando no sea este ente" (131). Y también nuestro sujeto en crisis trata de reconocerse y no se encuentra. Por tanto, la existencia del ser huye hacia sí misma, entra en crisis en la complejidad de lo humano.

Pasemos entonces, después de definir el sujeto en crisis, a mostrar su manifestación en las novelas de Cruz Kronfly que pretendemos interpretar.

La obra del sueño, publicada en 1984, cuenta diversas historias que se entretejen en el conflicto humano y las decisiones que deben enfrentar los personajes en cuanto al amor, la violencia y la muerte. Escrita desde diversos narradores, muchas veces en primera persona 
y desde narrador omnisciente, la obra, siguiendo el planteamiento de Bajtin en Teoría y estética de la novela (1989) es plurilingüística:

El discurso del autor y del narrador, los géneros intercalados, los lenguajes de los personajes, no son sino unidades compositivas fundamentales, por medio de las cuales penetra el plurilingüismo en la novela; cada una de esas unidades admite una diversidad de voces sociales y una diversidad de relaciones, así como correlaciones entre ellas (siempre dialogizadas, en una u otra medida) (81).

Y es la diversidad de voces y visiones de mundo que forman el discurso totalizante de la novela en sí. La obra, narra la vida de distintas parejas, la primera: Susana y Santiago. La segunda: Leopoldo y Genoveva. La tercera: Salomón Náder y Jimena, que es hija de Leopoldo y Genoveva. Además los sucesos giran alrededor de los personajes: Eloy Salamando, Alejandro, que es hermano de Leopoldo, Mario, sirviente de Genoveva, y diversos acontecimientos, entre ellos el conflicto social, la descendencia del personaje bíblico Abraham y la historia graciosa de Polvo de los Caminos, una yegua, que genera en la novela un aire fantástico y onírico. La manifestación del sujeto en crisis en La obra del sueño, la simboliza Leopoldo, este personaje es hijo de Santiago y Susana. Su padre, quien vive en Dinamarca, lo quiere sacar de la ciudad, pues al parecer la violencia los invade. Santiago ha perdido cinco de sus hijos, y desea que Leopoldo sobreviva. Para hacerlo, lo introduce en un baúl y pide a su criado Federico que lo saque en el lomo de una yegua hacia una parte distante donde pueda salvarse. De Dinamarca a Jericó es conducido Leopoldo al lomo del animal. Es necesario mencionar que no se sabe con exactitud si el narrador se refiere a los pueblos del departamento de Antioquia, Colombia, o Jericó, una ciudad antigua cerca a Palestina en medio oriente. La obra, que cambia de escenario con cada capítulo, luego relata que Leopoldo se casa con Genoveva y tienen dos hijas: Patricia y Jimena, las cuales son cuidadas por Mario, sirviente de Genoveva. Leopoldo es un personaje complejo y desencantado del mundo. El narrador pone en el personaje una postura del fracaso de la modernidad, de lo que genera la crisis del sujeto que describimos en el primer apartado de este capítulo, que menciona que la postura sobre la cual la humanidad avanza hacia un progreso humanístico, donde todos los seres humanos 
viviremos en igualdad de condiciones, dignamente, en un mundo incluyente en que la tecnología y los avances de la ciencia ayudarán a cerrar las distancias entre pobres y ricos, entre países tercermundistas y de avanzada, es una falacia que el siglo XX y parte del XXI, han demostrado; como lo afirma el sociólogo John Gray en El silencio de los animales Sobre el progreso y otros mitos modernos: "La ciencia y la idea de progreso pueden parecer unidas, pero el resultado final del progreso en la ciencia es mostrar la imposibilidad del progreso en la civilización" (2013:70). Y es esa imposibilidad de avanzar donde el ser humano naufraga en la complejidad de la existencia y que se ve refractada en La obra del sueño. Leopoldo es consciente del tiempo en que vive, de la infelicidad en el capitalismo y de las guerras por el poder y no por el progreso humano:

Esta era la manera como usualmente se expresaba Leopoldo, quien por andar filosofando acerca de este tipo de generalidades nunca conseguía hacer nada concreto: "Pertenezco a la gran estirpe de los pensadores tristes para quienes el mundo a duras penas tiene la consistencia de la mierda, tal como en cierta oportunidad lo alcanzó a insinuar mi inigualable maestro Jean Paul Sartre", solía decir en aquellos momentos en que sus amigos le retaban para que asumiese una actitud más positiva delante de los principales problemas del país (1984:20).

Leopoldo tiene angustia de enfrentar el mundo. No cree en la prosperidad de su país, ni en Dios, ni en nada. La melancolía y la tristeza que lo abarca, característica del existencialismo, de los conflictos humanos, de la novela misma en que se describe la marginalidad y la lucha por sobrevivir, lo embargan. Es el único personaje de la obra que crea Cruz Kronfly, capaz de reflexionar sobre su entorno, el único inmerso en la crisis del sujeto:

Viéndolas jugar de esta manera, absortas en sus sueños y en sus mundos imaginarios, quién de entre todos nosotros, habría de imaginar con algún fundamento que Leopoldo se había comportado como un verdadero visionario, sí como un vidente, cuando desde su lecho enfermo solía gritar que ahora que me muero para siempre, sí señores, ahora que me ahogo entre este nauseabundo mar de inmundicias y de mierda es bueno que se den por enterados de lo siguiente: estamos, sin haberlo percibido siquiera, en el centro de la tercera guerra mundial. Que no? Ya lo habrán de ver malparidos! Ya lo habrán de ver (70).

En la cita se muestra la percepción de Leopoldo hacia el mundo que enfrenta. La crisis del sujeto la crea el desencantamiento del entorno, de la historia, de la sociedad. Este personaje, que ocupa un lugar de relevancia en la obra porque todos los sucesos significativos giran 
alrededor de él, no evade la realidad y la existencia como Genoveva, su esposa, sobre la cual haremos énfasis en nuestro segundo capítulo. El sujeto en crisis que se presenta en La ceniza del Libertador y La caravana de Gardel se manifiesta de forma distinta, sin embargo, la crisis de Leopoldo es evidente, porque sus diálogos demuestran el hondo abismo de su interior y la frágil sociedad que quizá no es la de todos, pero sí la que genera la crisis del sujeto.

Interpretemos entonces la manifestación del sujeto en crisis en una novela cumbre del escritor vallecaucano: La ceniza del Libertador, para observar y analizar las características del personaje que escapa a la realidad, al presente que enfrenta y a su misma existencia.

El viaje desdichado de Simón Bolívar por el río Magdalena, los postrimeros atardeceres, las noches de insomnio, en lo que creyó y soñó el Libertador de cinco repúblicas en sus últimos días marginales, son los ejes centrales de La ceniza del Libertador. Cruz Kronfly, logra humanizar al héroe mediante el dolor y la fatalidad humana. La novela, publicada en 1987, cuenta el viaje agónico del Libertador. El narrador relata que Bolívar navega en una embarcación de dos pisos llamada champán; quisiéramos mencionar que el Libertador en realidad viajó en una barca sencilla. Cruz Kronfly crea una nave de dos pisos para elaborar un mundo alterno y una tensión que guiará la obra. A bordo del champán lo acompañan el coronel Santana, su sobrino Fernando y su fiel sirviente José Palacios. En el transcurso del viaje ocurren acontecimientos que generarán cierta tensión en la obra. Bolívar y sus hombres descubren que no son los únicos navegantes que ocupan la embarcación. En el segundo piso otras personas los acompañan. Este suceso es importante porque el Libertador y sus hombres planean una arremetida contra ellos. Existe también un personaje misterioso que observa al Libertador en las tardes. Al parecer es una persona que no pertenece al mundo novelesco y consume una bebida que viene en tarros de lata, similar a una cerveza. Bolívar espera con impaciencia un pasaporte y dinero para irse a otro lugar. El pasaporte nunca llega, en su lugar recibe una carta de Uldarico Clavel, personaje principal de la novela de Fernando Cruz Kronfly: Falleba. Bolívar está muy enfermo, su agonía y deseos de vomitar por la borda muestran un ser humano desdichado y moribundo. En medio del viaje el Libertador observa visiones, el concepto objetivo de realidad es suplantado por una 
realidad subjetiva. Al final la embarcación llega a Sabanilla y Bolívar, acompañado de Palacios y Fernando, es conducido a Santa Marta en un cajón de madera. El héroe encuentra la muerte en tierra firme y Cruz Kronfly logra crear un sentimiento de empatía hacia el Libertador de cinco repúblicas. La muerte y el dolor humano son fundamentales en la característica del personaje de Bolívar, sobre ello Darío Ruiz Gómez en Literatura, historia, circunstancia, en su estudio "Fernando Cruz Kronfly: Razones de la escritura" refiere: "La muerte agrega sentido a la vida al incorporar la medida de la caducidad" (2007). Y es esa caducidad humana que se percibe a lo largo de toda la obra. Aunque el autor vallecaucano nos muestre un Bolívar enfermizo, pensamos que se podría recuperar, cuando muere, nos sensibilizamos ante el dolor y la ilusión derrotada de un héroe.

Es necesario, antes de interpretar el sujeto en crisis, explorar la manera como está construida la obra. La poesía en verso libre y la prosa que indaga metáforas simbólicas, forman el entramado discursivo de la novela. Sobre ello, Alfonso Vargas Franco, en su investigación: "La desesperanza y la muerte en la novela La ceniza del Libertador de Fernando Cruz Kronfly”, publicada en la revista Poligramas, menciona:

De la misma manera, La ceniza del Libertador gustará especialmente a los amantes de la poesía, vivida "en su sentido más amplio y desaforado", como diría Darío Jaramillo Agudelo, porque ésta se encuentra vinculada en forma directa con el relato del drama humano de Bolívar. La metáfora, la comparación, las imágenes y los epítetos; la descripción de la naturaleza y del devenir existencial del hombre fracasado y miserable, son los recursos estilísticos de los cuales se vale el escritor para crear una atmósfera de desesperanza y muerte" (2004:172).

Y es en el recurso de la poesía y las imágenes de la muerte donde se crea una poética de la melancolía y la nada. Queremos señalar que el trabajo citado anteriormente de Alfonso Vargas Franco, indaga la estética de la lengua y el sufrimiento del héroe en la obra del autor vallecaucano. El primer poema que inserta Cruz Kronfly en La ceniza del libertador aparece en el capítulo cinco:

Sombras, negrura en los bordes de encajes de hilos plomizos Negrura en el centro del corazón oscuro

Silencio

Viento 
Agua y viento

Tinieblas tibias, vientos y agua

Lo oculto

La caída sin retorno

Morir mismo (99).

Se puede ver, desde la misma manera como están organizadas las líneas, que son versos libres. La figura de la reiteración de la palabra negrura del primer y segundo verso crean una sensación simbólica de desesperanza. Las imágenes de sombras, las tinieblas, la caída y el morir, generarán parte esencial del sujeto en crisis que pretendemos plantear. Antes de continuar, es necesario señalar la rigurosa investigación de los autores Myriam Posada, Adriana Gordillo y Carlos Rodrigo Castro, titulada: El ideal glorioso del héroe derrotado. Análisis lingüístico-literario de La ceniza del Libertador de Fernando Cruz Kronfly. En este trabajo se realiza un análisis detallado y estructural sobre los capítulos de la novela que insertan los respectivos poemas. Además, los autores encuentran elementos intertextuales de La ceniza del Libertador con poemas de Fernando Pessoa, y obras historiográficas como Simón Bolívar de Gerhard Masur, Bolívar de Indalecio Liévano Aguirre, entre otros. Es interesante observar que los autores terminan exaltando la figura de Bolívar:

Simón Bolívar era un hombre de concepciones grandiosas, que sabía claramente lo que quería: Construir varias repúblicas bajo la idea de una gran unidad continental. Pero sabía que esa gran empresa sólo se cumpliría si inculcaba en el pueblo la solidaridad americana. Por esta razón, el destino de Bolívar era no tener reposo ni aún después del triunfo en el campo de batalla" (1994:104).

En nuestra investigación no asumiremos una posición subjetiva sobre la heroicidad histórica de Bolívar, interpretaremos su figura y manifestación con base en una hermenéutica del lenguaje y la realidad novelesca de La ceniza del Libertador, ya que siguiendo a Milán Kundera en El arte de la novela: "Ahora bien, no me cansaré de repetir: la única razón de ser de la novela es decir aquello que tan sólo la novela puede decir" (2009:29). Y lo que dice la novela, el discurso simbólico por excelencia, será el espacio donde aventuraremos nuestra conjetura.

Bolívar no tiene una conciencia de su existencia. Su espacio es la memoria e imágenes pasadas que vuelven de la nada para hacerlo vivir en un mundo onírico. Cruz Kronfly, hace 
que su personaje principal evada la realidad. Se produce entonces un planteamiento desarrollado por Heidegger en El ser y e l tiempo: "El "ser ante los ojos" es, empero, la forma de ser de un ente que no tiene la del "ser ahí" (1993:130). Y ese ser ahí que no tiene forma es también el personaje de Bolívar que escapa al presente. El Libertador, no tiene existencia propia, más bien vive de los acontecimientos pasados, de la memoria de sus triunfos, batallas, amores; por ello es solitario y se entrega al recuerdo, donde las aguas del río Magdalena acompañan el viaje del héroe vencido por el tiempo y la distancia. Cruz Kronfly, desde el capítulo uno, comienza a crear un ambiente de la crisis del sujeto, la desdicha, el recuerdo, la melancolía: "Pero los hombres, aquellos los peregrinos de la despedida, ellos los tristes de largas quijadas mudas parecen no querer moverse de sus sitios, pues con el encanto de su quietud viven la ilusión de un tiempo muerto, estancado en aquel presente cuya transformación en pasado todos evitan" (16). La cita es esencial para comprender el sujeto en crisis que no enfrenta el presente y escapa a la realidad. En el transcurso de toda la obra Bolívar vivirá en otro espacio: "Y recordó aquellas alcobas cerradas de su casa en San Mateo, allá en Aragua, ocupadas de viejos muebles inservibles, telas deshechas y túmulos de papeles que al contacto con la luz despedían aquella especie de peluza picante a la nariz. Escucha a Hipólita estornudar, la percibe con un trapo de colores amarrado a su frente" (23). Es interesante analizar que el narrador en la anterior cita, después del recuerdo de Bolívar, utiliza los verbos en presente: Escucha, percibe; por tanto Bolívar no tiene una conciencia del momento en que vive, su realidad se alterna con los recuerdos, y aparece el personaje de Hipólita que fue su sirvienta. Más adelante, en un pasaje donde caminan el coronel Santana, que siempre albergó la esperanza de ver en perfectas condiciones al Libertador y tomar de nuevo el poder, junto con Palacios, Bolívar huye del momento en que vive, el ser no tiene la conciencia de sí mismo:

-Vamos, muchachos, vamos andando que a ustedes también les interesa el asunto. Vuelve a toser. Pero esta vez la convulsión es más leve. A lo lejos, un intervalo de alas nubes. Comienza el cielo de la noche. Y caminó: Vio el sol, envuelto como un regalo de pascua entre papeles todavía encendidos, tibio alboroto de rescoldo. De repente empieza a percibirlo todo más nítido que nunca, más luminoso. Lo lejano y lo próximo convertidos en acuarelas, claras de huevos chorreados, objetos del pasado. Ahí está Charles Moore, su médico inglés, un verdadero mueble de lujo. Y lo ve como siempre lo ha visto: sólo un pobre hombre tristemente tímido, manos regordetas, esplendoroso uniforme de legionario (52). 
Es así que Bolívar escapa de la realidad y vive diferentes momentos de su pasado. El sujeto en crisis en La ceniza del Libertador se refugia en la memoria, y esta tiene un carácter simbólico en la fenomenología de la imaginación, que según Gilbert Durand en Las estructuras antropológicas de lo imaginario (2004) tendría la función de invertir la semanticidad simbólica y lograr eufemizar las calamidades de la existencia. No queremos ser tautológicos y caer en el error de la repetición, basta con decir que la obra muestra muchos ejemplos del sujeto en crisis que evade la realidad. El Libertador no tiene una conciencia plena de sí mismo. Al final de la obra, Bolívar camina al lado de Palacios y no logra tener coherencia en sus diálogos, cree ver a Anita, una mujer que conoció hace tiempo, en la obra se lee:

-Vamos, vamos por allí, sígueme: ¡mira qué lindo! Anita, Anita, ¿dónde te has metido?

Otra vez desaparece toda frontera entre los días y las noches. Oscuridad en redondo, una gran luna en el centro del cielo. En la casa se duerme, gran silencio (339).

Se puede observar en la cita, las palabras del narrador que logran desaparecer el sujeto: Otra vez desaparece toda frontera entre los días y las noches. Por tanto, el sujeto en crisis en La ceniza del Libertador, se manifiesta en Bolívar que escapa de una realidad marginal que al final lo lleva a la muerte. Para terminar, quisiéramos mencionar que Fernando Cruz Kronfly desmitifica al héroe y lo humaniza a través del dolor. A partir de la crisis del cuerpo débil y enfermo que solo espera la muerte que lo libere de la derrota de sus ideales y la carga existencial. Simón Bolívar se describe en la novela como un personaje marginal, que ha sido derrotado no sólo por sus acciones o enemigos, sino por el tiempo y la enfermedad que lo consume. El Libertador, aunque conserva su reputación de héroe ante el pueblo, siente que sus días de gloria terminaron, que ya no liberará a nadie y necesita ser liberado. En la obra se menciona:

Empujados río abajo los héroes ya no saben si resignarse o si lanzar un último coletazo. Sería posible pero ya nada vale la pena. Sólo soñar un pensil, lugar invisible, morir con honor, vomitar a tiempo. Acusados de transgredir el inasible espíritu de la ley, los héroes deben defenderse ahora de ser tratados como traidores, proseguir un viaje a ciegas donde todo es desconocido (203). 
La cita muestra un héroe derrotado, humillado, que ya no realiza la hazaña libertadora, y podría ser un traidor a la patria para los nuevos legisladores del Estado por transgredir el supuesto inasible espíritu de la ley.

La construcción imaginaria del héroe se derrumba totalmente en la novela de Cruz Kronfly, tanto, que se muestra la melancolía y la profunda tristeza del Libertador. Aunque el autor describe con fino detalle naturalista las náuseas, la debilidad corporal y las ganas insoportables que siente Bolívar por vomitar, es en la gloria pasada y en el destierro de la patria donde más se humaniza al héroe. El Libertador no sufre tanto por su cuerpo, lo agobia el destierro de su patria:

La patria, la tibia patria donde nació, donde aún se levantan aquellos muros, aquellas ventanas floridas en el patio donde florea la fuente, allá en San Mateo, cálidos valles de Aragua, esa patria no quiere verle más, lo destierra. Y exige de Colombia su expulsión del territorio como condición para el restablecimiento de las relaciones. Llora. Entre sombras, llora lo innombrable (268).

Es así que el héroe se destroza en la complejidad de lo humano. Cruz Kronfly muestra un héroe que mira con nostalgia la patria que ya no le pertenece.

Interpretaremos entonces la manifestación del sujeto en crisis en La caravana de Gardel.

El transporte del cuerpo del ícono del tango: Carlos Gardel, la tristeza del hombre moderno, la melancolía, vacío existencial de sus personajes y en cierta manera el fracaso de la modernidad, son los sucesos principales de la novela de Fernando Cruz Kronfly: $L a$ caravana de Gardel. Publicada en 1998, desde un narrador omnisciente, la obra cuenta la historia del arriero Arturo Rendón que tuvo la misión, junto con su compañero Heriberto Franco, de transportar el cuerpo de Carlos Gardel a lomo de mula en los años 1935, cuando en Colombia existían pocas carreteras y la naturaleza era exuberante. La novela empieza narrando el presente de 1950, época de la violencia y masacre entre los partidos políticos: Liberal y Conservador. Arturo Rendón, sujeto en crisis que exploraremos más adelante, decide buscar a su compañero Heriberto Franco para reclamarle unas pertenencias de Gardel. A medida que avanza su recorrido, Arturo Rendón recuerda diversos sucesos del viaje, y el narrador, a lo largo de la obra, nos hace vivir dos momentos: presente y pasado. Sobre las técnicas narrativas utilizadas en la obra, el teórico César Valencia Solanilla en su 
texto: "El tango y la modernidad en La caravana de Gardel, de Fernando Cruz Kronfly", publicado en la Revista Ciencias Humanas, realiza un minucioso estudio:

En su estructura interna, La caravana de Gardel está armada en torno al viaje, con interacción y paralelismo espaciales y temporales. Es un recurso narrativo que en esta obra tiene un matiz interesante, pues se da en dos tiempos: en el presente de la narración, como búsqueda de las reliquias de Gardel en el periplo de Arturo Rendón; en el pasado, como jornada de trabajo con una recua de mulas desde la Pintada hasta Anserma trasladando los restos del cadáver de Gardel: (2000:53).

Por tanto el tiempo es fundamental para comprender el universo discursivo de la obra.

El cronotopo, que según Mijaíl Bajtín en Teoría y estética de la novela, señala espacios y tiempos, reales o no, guían el suceso de la narración y le dan vital importancia a la creación estética. Al respecto, plantea: "Vamos a llamar cronotopo (lo que en la traducción literal significa «tiempo-espacio») a la conexión esencial de relaciones temporales y espaciales asimiladas artísticamente en la literatura (1989: 237). Y son las relaciones entre pasado y presente las que llevarán el hilo conductor de la historia. Es necesario mencionar que Bajtín argumenta que en la novela contemporánea el tiempo se complejiza y se vuelve en un recurso escritural. Existen diversas cronotopos de tiempo y espacio, que se pueden interpretar según la intención del lector:

Lo importante para nosotros es en este caso lo siguiente: sean cuales sean las significaciones, habrán de adquirir, para incorporarse a nuestra experiencia (además experiencia social) algún tipo de expresión espacio-temporal, es decir, una forma semiótica que sea oída y vista por nosotros (jeroglífico, fórmula matemática, expresión lingüísticaverbal, dibujo, etc.). Sin esa expresión espacio-temporal, ni siquiera es posible el más abstracto pensamiento. Por consiguiente, la entrada completa en la esfera de los sentidos sólo se efectúa a través de la puerta de los cronotopos (408).

Y la puerta del cronotopo, como lo señala la cita, en La caravana de Gardel es el tiempo y el espacio donde el sujeto en crisis logra evitar el presente que enfrenta. Cruz Kronfly mediante el recuerdo del personaje principal inserta en el relato un tiempo pasado que alimenta las esperanzas del arriero Rendón y alivia por momentos sus pesares y el vacío existencial que arrastra consigo.

Arturo Rendón parte desde Medellín hacia Umbría. Conoce a una mujer de cantina llamada Amapola Cisneros, alias La Leona. Con esta mujer realiza parte del recorrido. El arriero, en 
el camino, recuerda cuando en compañía de su compañero Heriberto Franco y el comerciante Luis Gómez Tirado llevaron el cuerpo exhumado de Gardel por los pueblos de Supía, Valparaíso, Caramanta, Umbría, y Armenia, para entregar al cadáver y algunas reliquias que van en el ataúd a un hombre que lo transportaría en un ferrocarril con destino a Buenaventura y luego por el pacífico hacia Buenos Aires. Arturo Rendón y La Leona son testigos de la gran mortandad y la violencia que vive el país. En las carreteras observan cuerpos decapitados y mutilados. La Leona, al descubrir la infinita tristeza de Arturo Rendón lo abandona. El arriero, que en la novela es descrito de apariencia enigmática y bella, visita a un tío en Supía para prestar dinero y continuar con su travesía que tiene como objetivo conseguir algunas prendas u objetos personales de Gardel para montar un museo. Conoce en un bar a una joven prostituta llamada Dulcinea. Esta joven alias la Gata, sigue el camino con Arturo Rendón hasta Umbría. Al final, el arriero se da cuenta que Heriberto Franco fue asesinado dos años antes. La Gata, que pensaba conseguir dinero al lado de su hombre termina abandonándolo, el único consuelo de Arturo es que logra visitar a las dos mulas que transportaron el cuerpo: Alondra Manuela y Bolívar. La música triste del tango acompaña a los personajes y refracta los sentimientos de melancolía de una sociedad abandonada y desilusionada que se refugia en el sentimiento del tango. Arturo Rendón muere en una buseta de transporte a la que llamaban berlina de regreso a Medellín.

Hemos realizado un pequeño resumen para tener una idea general de los sucesos de la obra. En La caravana de Gardel, el sujeto en crisis, representado por Arturo Rendón, tiene una actitud de desesperanza ante el mundo y la ciudad. Los personajes que lo acompañan: La Leona y la Gata, son marginales y se encuentran abandonados por una sociedad, que en su furor genera una especie de desconcierto. Las investigadoras Lucía Moreno Parrado y Paula Andrea Marín en su trabajo Fernando Cruz Kronfly y la caravana de la modernidad en Colombia, además de estudiar la relación entre el ensayo y la narrativa de Cruz Kronfly, reflexionan sobre el mundo urbano y el sentimiento del tango, sobre ello argumentan:

La ciudad contiene el tango y ambos transforman al protagonista de la novela. Fernando Cruz Kronfly ubica a su personaje en la región antioqueña, la primera en avanzar hacia la industrialización; es en los bares de Medellín donde el protagonista tiene su encuentro con el tango y sus desencuentros con la humanidad. Medellín que, como todas las ciudades latinoamericanas, cada una a su ritmo, en las primeras décadas del siglo XX sintió la 
llegada de la era moderna a través del ferrocarril, los autos, los sonidos, las fábricas, las máquinas, las comunicaciones, la velocidad (2011:24).

Se genera entonces alrededor de los personajes el desencanto de la modernidad.

Álvaro Pineda Botero en Estudios críticos sobre la novela Colombiana 1990-2004, interpreta el papel del arriero en la Colombia de los años treinta y su relación con la modernidad: "En 1930, la arriería en Colombia era una profesión en decadencia, por el avance de las carreteras y los ferrocarriles. Los arrieros, que por siglos fueron los agentes de la comunicación, ahora perdían la fuente del sustento" (2005:177). Por tanto, Arturo Rendón que en principio de la modernidad en Colombia ocupó un lugar fundamental con la profesión de arriero, pues transportaban el correo y objetos de valor, sentía el cambio de los tiempos en una época violenta y marginal.

En la novela Arturo Rendón tiene una actitud desesperanzadora frente a la sociedad del momento. Se siente abrumado por el peso del mundo. Como si navegara a la deriva asume una actitud melancólica y de derrota. Quizá por ello abandona sin dudar su presente y emprende el viaje en busca del recuerdo no solo de una prenda de Gardel, también de otra época más incluyente. El sujeto en crisis está abatido en un tiempo que no le brinda ni le promete nada, por ello escapa de sí mismo y de las situaciones de su vida, niega su presencia y se refugia en la memoria. En la obra se menciona aquella actitud del sujeto en crisis que quiere huir y es embargado también por una profunda tristeza:

Sin saber las causas y a pesar de su aceptable estado general, Arturo Rendón se sentía ya muy abatido por el peso del mundo. Sospechaba haber caído en poder de un extraño desequilibrio del alma, ocasionado por una tristeza sin regreso que él poco a poco consideró insuperable debido a su carácter, tan aficionado a lo esencial a pesar del origen rústico de su espíritu. Intuía a su modo que había sido tocado por la desesperanza de los tiempos y se sentía cubierto de niebla de la cabeza a los pies (1998:8).

La cita muestra con claridad la crisis donde se encuentra inmerso el sujeto. Rodrigo Bastidas en la revista Hojas Universitarias, plantea en su investigación "La caravana de los incurables" el sentimiento urbano: "En este héroe, llamado Arturo Rendón, hay también algunos de los rasgos de desesperanza posmoderna, ya que su desplazamiento a la ciudad lo 
dota de una nueva sensibilidad: el vacío" (2011:24). Y es esa sensación de vacío característica de la crisis que se genera alrededor del sujeto.

En La caravana de Gardel el sujeto se encuentra en crisis, el ser no tiene una conciencia de sí mismo. Arturo Rendón vive del recuerdo y la ilusión de encontrar un jirón o alguna pertenencia de Carlos Gardel. Lo que lo ata al presente son sus amantes prostitutas que en realidad solo esperan que exista, pero el arriero vive en otro espacio y tiempo, el sujeto se evapora en la melancolía y la tristeza del tango. Arturo Rendón no tiene una conciencia de sí para existir. Es conveniente recordar que para Heidegger el ser es una posibilidad de ser ahí, un ente, que en la misma pregunta por su ser trata de hallarse, un sujeto en crisis. Arturo Rendón en todo su recorrido es alimentado por el recuerdo de sucesos pasados. Aunque tiene presencia física el ser y la nada en él son lo mismo, pues su conciencia se quedó anclada en el pasado, en la melancolía y tristeza del tango que acompaña el destrozo del hombre moderno que fue desencantado del mundo. En la novela se evidencia: "Entonces volvió a ver lo que desde hacía quince años lo traía tan embromado: dormía profundo, pero aun así estaba seguro de haber quedado arrastrando por el mundo aquella especie de certeza sin pruebas" (15). Lo que volvió a ver Arturo Rendón fueron las imágenes de una vida pasada, de un viaje donde no solo entregaba el cuerpo de Gardel, sino su vida, su existencia. Es importante mencionar que a partir del momento en que el arriero vuelve a recorrer los caminos transitados que anduvo en su juventud, es cuando más quiere huir de su presente y de sí mismo. El sujeto en crisis emprende una salida que niega su existencia. La leona, una mujer prostituta que conoce Arturo Rendón en su búsqueda por encontrar algún objeto de Gardel, se da cuenta de la tristeza, del vacío existencial del personaje principal que trata de encontrarse en un mundo lejano y perdido oculto laberinto de su memoria, veamos: "Ella veía que a veces él conseguía fijar sus ojos en todo aquello que ocurría en el parque iluminado, pero a pesar de este aparente interés por los sucesos del mundo le seguía notando una mirada vidriosa y lo sentía cada vez más cerca de sí y lejos de la realidad que hasta ahora lo sostenía (94). La Leona logra percibir el ensimismamiento de Arturo Rendón, luego lo abandona al descubrir la infinita tristeza y melancolía de su vacío existencial. "La maleta la tenían bajo la mesa y él masticaba su desayuno como si su 
pensamiento anduviera por otra parte y su cuerpo ya hubiera partido para dejar atrás sólo el peso de su sombra" (193). La cita evidencia el desprendimiento de la conciencia y el abandono del ser. Es así que el sujeto en crisis que se manifiesta en La caravana de Gardel escapa al presente y niega el Yo, se apega al recuerdo y al tango que expresa un sentimiento del hombre urbano hacia la modernidad.

Es interesante señalar la similitud de Umbría con Luvina, pueblo que describe el escritor mexicano Juan Rulfo en El llano en llamas, ambos abandonados a su suerte, la masacre y los muertos de estos lugares generan un ambiente lúgubre y sepulcral. En La caravana de Gardel encontramos:

Y entraron por la primera calle y vieron que las paredes estaban salpicadas de barro negro y que de los techos colgaban racimos de pájaros secos.

- Ya estamos llegando - dijo la Gata al oído de su hombre.

-iPor fin!

-Este lugar me asusta, mirá cómo ha quedado todo.

-Es el paraje más triste y cruel que hay en el mundo.

- ¿Vos sentís el mismo escalofrío que yo?

-Podría ser, pero aún siento que el clima me favorece.

- Hasta mi tía habrá muerto ya -dijo la Gata.

-Ésa es cosa que ya veremos.

Dichas que fueron estas elementales cosas se apearon y empezaron a caminar sobre la polvareda (196).

De manera similar, Rulfo describe en un diálogo de su personaje:

-Por cualquier lado que se mire, Luvina es un lugar muy triste. Usted que va apara allá se dará cuenta. Yo diría que es el lugar donde anida la tristeza. Donde no se conoce la sonrisa, como si a toda la gente le hubieran entablado la cara. Y usted, si quiere puede ver esa tristeza a la hora que quiera (1983:174).

En ambos lugares la tristeza y el desconcierto que sienten los personajes hacia los pueblos es evidente, quizá estos sitios, que cobran vida en la literatura, manifiestan el sentimiento de abandono y vacío existencial generado por una historia moderna de masacres y llanto.

El sujeto en crisis que hemos pretendido plantear en la interpretación de las tres novelas estudiadas: La obra del sueño, La ceniza del Libertador y La caravana de Gardel, del escritor vallecaucano Fernando Cruz Kronfly, muestran una negación del ser, no tienen una conciencia inmediata del presente que enfrentan. El sujeto en crisis se encuentra en un 
laberinto donde el Yo no reconoce la conciencia sobre su existencia. Por tanto, la negación del ser es la que se produce en los personajes de las novelas que se encuentran en crisis porque también tienen un desencanto del mundo en que viven. Es así, que tratamos plantear que el sujeto en crisis se genera en Cruz Kronfly debido al fracaso de la modernidad, al vacío del hombre contemporáneo que se ha desplazado a la ciudad y ha creído en el progreso humanístico de la modernidad que en sus principios fue muy sólido con la apuesta de la razón instrumental, luego el tiempo demostró lo contrario. Marshall Berman en Todo lo sólido se desvanece en el aire, argumenta lo siguiente:

«Todo lo sólido»- desde las telas y los talleres que las tejen, los hombres y mujeres que manejan las máquinas, las casas y los barrios donde viven los trabajadores, las empresas que explotan a los trabajadores, los pueblos y las ciudades, las regiones y hasta las naciones que los albergan-, todo está hecho para ser destruido mañana, aplastado o desgarrado, pulverizado o disuelto, para poder ser reciclado o reemplazado a la semana siguiente, para que todo el proceso recomience una y otra vez, es de esperar que para siempre, en formas cada vez más rentables (1988: 95).

La cita muestra con claridad la apuesta del proyecto moderno, donde todo debe ser reemplazado debido al consumo y al sistema económico que absorbe la sociedad de la inmediatez. Mostramos en la crisis del sujeto que Sigmund Freud en El malestar en la cultura, intuyó el principio de destrucción que genera el hombre en sociedad. Después de dos guerras mundiales, sin mencionar las guerras, los muertos y el hambre que se viveen medio oriente y también en algunos países latinoamericanos, quizá el progreso humanístico que empezó en la modernidad y continúa en la posmodernidad o contemporaneidad, no sea tan cierto. La literatura de Cruz Kronfly, refracta en cierta medida la desesperanza del hombre actual, y se sale de la liquidez de algunos escritores vacuos del momento. Intentamos mostrar las diferentes manifestaciones del sujeto en crisis. En La obra del sueño en el personaje de Leopoldo, en La ceniza del Libertador en Bolívar y en La caravana de Gardel a Arturo Rendón. Estos personajes se encuentran angustiados ante el mundo que enfrentan. No tienen una conciencia absoluta de la realidad que viven, evaden el Yo y escapan de sí mismos. Por tanto, el sujeto en crisis para tratar de hallarse recurre a su 
memoria que logra crear un espacio eufémico para aliviar la angustia que le produce el mundo.

Interpretaremos ahora la función de la caída y la memoria del sujeto en crisis. 


\title{
2. La caída y la memoria del sujeto en crisis
}

\author{
Como lo recalcaron bien los etnólogos, \\ este esquema de la caída no es otra cosa que el tema \\ del tiempo nefasto y mortal, moralizado en forma de castigo. \\ Gilbert Durand. Las estructuras antropológicas de lo imaginario.
}

La caída del sujeto en crisis se presenta de manera simbólica en las novelas de Fernando Cruz Kronfly: La obra del sueño, La ceniza del Libertador y La caravana de Gardel. En el capítulo anterior, señalamos que el sujeto en crisis escapa al presente y no tiene una conciencia del momento en que vive, el ser no se devela, y por tanto, siguiendo la tesis del filósofo alemán Martin Heidegger, el ser solo es ser ahí, un ente frágil que trata de develar su existencia. El contexto histórico y social del sujeto en crisis que describimos es la posmodernidad o contemporaneidad, donde tratamos de demostrar basados en textos como Modernidad Líquida (2002) y Todo lo sólido se desvanece en el aire (1998), que existe un desencanto del mundo moderno. Es así, que el entorno del sujeto en crisis es desesperanzador, y las novelas que estudiamos logran refractar esa realidad. La caída que se manifiesta en las obras del escritor vallecaucano muestra el sentimiento de abandono y en cierta medida, en el caso de La ceniza del Libertador, el sufrimiento y el vértigo del héroe. La memoria crea un espacio de refugio para el sujeto en crisis donde el tiempo se detiene y eufemiza por cierto momento las calamidades humanas. Los símbolos se invierten.

Interpretaremos entonces, en un primer momento la caída, luego observaremos el papel de la memoria. Ambos: caída y memoria, serán símbolos que se transforman. Desarrollaremos la teoría del fenomenólogo de la imaginación: Gilbert Durand, expuesta en Las estructuras antropológicas de lo imaginario (2004), en las cuales el símbolo se dinamiza bajo el 
régimen diurno y el régimen nocturno de la imagen, los cuales explicaremos en el transcurso de nuestra conjetura.

\subsection{La caída del sujeto en crisis}

Gilbert Durand perteneció a la Escuela de Eranos, la cual fue fundada por un discípulo de Sigmund Freud, Carl Gustav Jung en 1933. En ella había representantes de distintas disciplinas y ciencias, que tenían como objetivo encontrar puntos de convergencia entre sus especialidades y la teoría junguiana del inconsciente colectivo, la cual postula una unión entre el hombre antiguo y el hombre contemporáneo por medio de símbolos. La obra capital de Durand Las estructuras antropológicas de lo imaginario, publicada en 2004 por el Fondo de Cultura Económica, defiende una teoría de la imaginación simbólica. La imagen, es decir lo que se imagina, posee un significado propio que se devela en el símbolo poético. Aunque la obra de Durand bebe de la filosofía, la antropología, la historia de las religiones, la química y la literatura, es en la fenomenología donde encuentra su quid. El teórico francés se apoya en distintos autores, entre ellos algunos destacados de la Escuela de Eranos: Gaston Bachelard y Carl Gustav Jung, para describir una fenomenología que explica los fenómenos no en un sentido empírico positivista, sino en una interpretación simbólica que se alimenta de la cultura y la energía pulsional donde se encuentran inmersos. Es vital mencionar el concepto de trayecto antropológico y el arquetipo que menciona Durand para explicar el carácter del símbolo y su relación con el medio, el teórico citando a Jung señala:

Jung puso claramente de manifiesto el carácter de trayecto antropológico de los arquetipos cuando escribe: "Incuestionablemente, la imagen primordial debe estar en relación con ciertos procesos perceptibles de la naturaleza que se reproducen incesantemente y siempre están activos; pero, por otra parte, también es indudable que igualmente se relaciona con ciertas condiciones interiores de la vida del espíritu y de la vida en general" (2004:63). 
Las relaciones que menciona la cita entre la imagen primordial, arquetipo, y la vida del espíritu en general, se refieren al trayecto antropológico, a la incesante interpretación que se le puede dar al símbolo respecto a su cultura y tiempo. Es necesario, antes de estudiar la representación simbólica de la caída en las novelas de Cruz Kronfly, conceptualizar el esquema, el arquetipo y el símbolo en Gilbert Durand.

Durand realiza una diferencia entre esquema, arquetipo y símbolo. El esquema hace referencia al lugar, a la cultura y trayecto antropológico que pulsa relaciones de sentido e interpretación en la imagen, que también representa un símbolo. Durand menciona "El esquema es una generalización dinámica y afectiva de la imagen, constituye la facticidad y no la sustantividad general del imaginario" (62). El autor al no definir la sustantividad general del imaginario se refiere a que el esquema forma un dinamismo en la imagen que ayuda a su interpretación, en el caso que nos compete, el esquema será lo que acompaña al símbolo, en otras palabras, las relaciones de sentido que se podrían encontrar para interpretar la manifestación simbólica de la caída. El arquetipo, categoría dinámica y no estática, que el autor toma en préstamo de Carl G. Jung, no cae en un monismo metafísico, se relaciona con el mito que tiene un carácter universal y se representa mediante el símbolo. A lo largo de su obra, Durand señala diversos símbolos que arquetípicamente en culturas ancestrales han simbolizado la ascensión y la caída. Sobre ello el estudioso de la imaginación menciona "Todo pensamiento simbólico es, en primer lugar, símbolo de conciencia de grandes símbolos hereditarios, suerte de "germen" psicológico, objeto de la paleopsicología" (42). Aquellos símbolos hereditarios son los arquetipos, prototipos que Durand analiza en distintos mitos arcaicos, que se renuevan mediante el rito. El autor francés no define el símbolo, lo utiliza como una manifestación mitológica y polivalente que se devela en relación con el arquetipo y los esquemas que lo rodean. El símbolo sería una aparición que busca trascender los sistemas de significación mediante el lenguaje y la imagen poética. En las novelas de Fernando Cruz Kronfly: La obra del sueño, La ceniza del Libertador y La caravana de Gardel, los personajes principales caen al abismo de la desesperanza humana. El sujeto en crisis cae y agoniza en la marginalidad. Esta caída se encuentra dinamizada en lo que Gilbert Durand llama el régimen diurno de la imagen. 
Explicaremos entonces las características de este régimen y su implicación semántica con relación con las obras estudiadas.

El símbolo de la caída en las novelas de Fernando Cruz Kronfly se muestra primero bajo el régimen diurno de la imagen; luego la caída se eufemiza bajo el régimen nocturno. Al régimen diurno le corresponde la lucha antitética de los símbolos, la luz y la oscuridad. Durand explica:

Por consiguiente, será muy naturalmente como se dividirán en dos grandes partes antitéticas los dos capítulos dedicados al Régimen Diurno de la imagen: la primera -el sentido de cuyo título será dado por la propia convergencia semántica- estará consagrada al fondo de las tinieblas sobre el cual se recorta el brillo victorioso de la luz y la segunda manifestará la reconquista y metódica de las valoraciones negativas de la primera (69-70).

La cita describe la antítesis entre las tinieblas y el brillo victorioso de la luz. El régimen diurno, que es en cierta medida un esquema que acompaña al símbolo, muestra primero las representaciones oscuras y terroríficas. Bajo la figura de Cronos, dios griego que simboliza el tiempo, Durand menciona los símbolos teriomorfos: animalidad; nictomorfos: noche y lo siniestro de lo oscuro; catamorfos: caída y angustia. El autor francés enfatizará en que estos símbolos están irremediablemente en una lucha constante contra el tiempo, por ello la angustia del régimen diurno y la oposición antitética entre la luz y la oscuridad. La figura de Cronos devorando al hombre. Lo que nos interesa de lo mencionado es analizar la caída que en la constelación de Durand estaría dentro de los símbolos catamorfos. Por tanto, es una catamorfía la que se presenta en las novelas de Cruz Kronfly, una caída que espanta al sujeto en crisis porque el tiempo se le escapa, porque Cronos lo termina.

Los símbolos catamorfos, como lo mencionamos anteriormente, están animados por el subsuelo, por la caída que genera una sensación de angustia. Durand al hablar sobre las representaciones de lo catamorfo plantea: “A nuestro juicio, la tercera gran epifanía imaginaria de la angustia humana ante la temporalidad debe ser suministrada por las imágenes dinámicas de la caída” (116). Y más adelante menciona: “Como lo recalcaron bien los etnólogos, este esquema de la caída no es otra cosa que el tema del tiempo nefasto y mortal, moralizado en forma de castigo" (118). Lo que describe el autor, la angustia de la 
caída y el tiempo que consume al hombre, es lo que se manifiesta en las novelas de Cruz Kronfly, entraremos entonces a indagar las imágenes de los símbolos catamorfos que generan una incesante sensación de desprendimiento y vacío en el sujeto en crisis.

En La obra del sueño, la imagen de la caída está representada simbólicamente mediante el destierro de Leopoldo. Este personaje, que mencionamos en el capítulo anterior, es desprendido de su madre, su pueblo y su familia. Santiago, el padre de Leopoldo, por culpa de la violencia del lugar, introduce a su hijo dentro de un baúl y lo sube al lomo de una mula para que vaya a su suerte por el mundo y sobreviva a la mortandad que lo rodea. Leopoldo, que en la obra es descrito como un filósofo, siente el vértigo de la caída, el desprendimiento del seno de su madre a la que ama como a nadie en el mundo. La imagen de la caída se simboliza en su destierro, ya que es alejado de su patria y de su tierra natal. El sujeto en crisis cae hacia un mundo desesperanzador que no le brinda una estabilidad, si no violencia y abandono. Veamos el siguiente diálogo de los personajes para argumentar nuestra conjetura:

- He decidido contra todo lo que puedan pensar esos locos tunuantes a quienes tú consultas con tanto misterio, que con la primera oscuridad de esta misma tarde te habrás de marchar con destino a Jericó.

- Ya lo sé papá -respondió Leopoldo.

- Sí, es cierto que ya te lo he dicho en varias formas, pero pareces no haberte dado por enterado.

- Por qué lo dices? -Preguntó Leopoldo.

- Por nada, hijo. Pero ocurre que no es sino mirar tus ojos para saber que nada de todo cuanto estoy haciendo con tanto esfuerzo para salvar tu vida tiene el menor interés para ti

- Porque tratas de salvarme de una manera históricamente equivocada. Dijo Leopoldo, mientras introducía ambas manos en los bolsillos delanteros de su pantalón.

No te comprendo -exclamó Santiago-. Sólo sé que a cinco de tus hermanos mayores se los llevó la violencia y que ahora, viejo y cansado, requiero de tu ayuda (1984:30).

La cita muestra la decisión de Santiago de sacar a su hijo lejos de la casa. Leopoldo, con una actitud desesperanzadora lo ignora. Se percibe en la respuesta del personaje cierto rechazo de abandonar su hogar, se abstrae en pensamientos vacuos y evita el presente. El sujeto en crisis comienza una caída simbólica que lo hará alejarse por siempre de sus 
tierras. Leopoldo sabe que por más que su padre quiera protegerlo, la sociedad en que se encuentra inmerso camina hacia guerra, su tiempo se termina:

-Está bien padre se hará lo que tu diga.

Enseguida agregó:

-Me marcharé a Jericó y me ocultaré entre las ruinas heladas. Pero por más que logre sobrevivir, la violencia continuará siendo la única alternativa del destino de muchos nosotros.

Se detuvo por unos cuantos segundos y finalizó:

-Aún hoy es válida aquella sentencia según la cual el hombre es un lobo para el hombre (32).

Leopoldo acepta marcharse y comprende que su caída hacia el abismo es inevitable. La cita de Joseph Conrad que se muestra en el diálogo: el hombre es un lobo para el hombre, exhibe la capacidad de destrucción humana. Leopoldo, además de saber el fracaso de la modernidad, sabe que los años de paz y armonía que le brindaba su casa se terminan. Los símbolos catamorfos animados por el arquetipo de la caída y el tiempo que devora al ser humano se develan ante el sujeto en crisis. Interpretemos ahora estos símbolos en La ceniza del Libertador.

El destierro político y el tiempo que devora a Bolívar en La ceniza del Libertador son los símbolos catamorfos en la novela. El Libertador cae del poder, de la imagen de héroe que antaño conservaba. Es evidente que Cruz Kronfly nos muestra un Bolívar derrotado, podríamos decir de manera general que la obra narra la historia de una caída, de un personaje enaltecido que desciende del pedestal y se humaniza en la dinámica catamorfa del descenso. El tiempo consume al Libertador, Cronos se muestra despiadado y el héroe se entrega a sus dominios. Desde el principio de la novela se manifiesta la imagen de la caída:

\footnotetext{
Abajo, en el río, aguardan las naves. Cáscaras de un viaje que apenas comienza pero que podría ser el del final. Como en medio de un insomnio, las embarcaciones se mueven quietas. Durante toda la noche en él no hubo sueño sino simple visión interior, llamados de otros tiempos, días. Visión de todo y de nada. Casi lo perfecto de un vacío asediado por la urgencia de lo desconocido. Tal vez así mismo debiese ser, porque Su Excelencia viene de la luz de todas las glorias imaginables.

Viene de los párpados beneméritos, casi de la santidad.

Y sin embargo de todas sus glorias pasadas debe enfrentar el destierro, la impugnación de la baba, la pavorosa nada de un viaje que no es de huída de lo concreto sino simple hijo del desengaño.
} 
Su excelencia ha decidido partir para siempre (1987:10).

En la cita se describe el inicio del viaje que es el principio de la caída. Bolívar ha sido desterrado de la patria que ayudó a libertar, pero además su tiempo de héroe ha terminado, su misma vida culminará con el viaje. La imagen del Libertador finaliza, igual que todos sus propósitos para con la patria, el pueblo es testigo de su desprendimiento del poder:

Siempre vivas y a veces pensamientos, rosas de jardín y hasta flores de mayor talante. Pero de repente y como venido del centro del río donde el vapor acaba de desaparecer, se escucha un grito:

- ¡Que cesen los homenajes!

Todos volvieron sus ojos al vacío. Y escucharon de nuevo:

- ¡No es un héroe el que se marcha sino un tirano despreciable! (15).

Es así que la imagen del Libertador se derrumba. El tiempo del héroe termina. La caída simbólica de Bolívar comienza con su destierro y termina con su muerte. Cruz Kronfly, a lo largo de la obra nos muestra un sujeto en crisis que se desprende del poder y la gloria y culmina en la demencia y lo marginal de lo humano.

Arturo Rendón, sujeto en crisis en La caravana de Gardel, también cae hasta el abismo de la muerte. Su obsesión por recuperar alguna de las cosas personales del cantante argentino Carlos Gardel, lo lleva a abandonar su propia vida y a deambular en busca de un objeto irrecuperable por la Colombia violenta de los años cincuenta. Los símbolos catamorfos, animados por la caída y el tiempo que destruye al ser humano, son claros en la obra. Arturo Rendón, después de quince años abandona su empleo y piensa en el tiempo perdido que estuvo sin alguna prenda de valor de Gardel. Este personaje emprende la aventura y comienza su caída hacia la crisis. A lo largo de la obra, Cruz Kronfly, nos muestra que el arriero cae en la melancolía, las mujeres que consigue lo abandonan. Al final, cuando descubre que su compañero de viaje Heriberto Franco, con quién años atrás transportó el cadáver de Gardel, fue asesinado dos años antes de su visita, Rendón entra en el abismo de la melancolía y al tratar de regresar a casa muere en una berlina. Por tanto, la simbología de lo catamorfo es representada en la angustia del viaje y el tiempo que se termina para Arturo Rendón. En el numeral dos de la obra encontramos: “Arturo Rendón caminó hasta la puerta, lentamente, como si se estuviera despidiendo de aquel lugar para toda la vida. No podía desterrar de su cabeza a Heriberto Franco" (1998: 18). Desde el principio del viaje el 
autor comienza a señalar la angustia y necesidad que siente Arturo Rendón para emprender el viaje. Al final de la novela, cuando el arriero ha terminado todo su recorrido se menciona: "Después de pasar por el rancherío del otro día, ante cuyos niños hinchados y desnudos, perros y cerdos Arturo Rendón tuvo por primera vez el presentimiento de su muerte, la berlina tomó su descenso hacia el lecho del río" (224). En la cita se muestra el presentimiento que siente Rendón hacia la muerte. Los símbolos catamorfos del tiempo irremediable que termina con la vida humana, de la angustia de la caída son claros en la obra. El arriero, desde que deja su casa va en busca del final de sus días.

En este apartado tratamos de demostrar que el arquetipo de la caída y el tiempo en las tres obras estudiadas: La obra del sueño, La ceniza del Libertador y La caravana de Gardel, son claves para entender la angustia del sujeto en crisis. Los personajes principales de las novelas caen simbólicamente a la desesperanza, vacío existencial y finalmente encuentran la muerte. Se crean ideales que no conseguirán. Aunque en forma distinta, el arquetipo de la caída se devela por medio del símbolo para dar una característica particular a la obra. Pasaremos a interpretar el papel de la memoria, que es un espacio que eufemiza las calamidades del sujeto en crisis.

\subsection{La memoria, el escape del sujeto en crisis}

La memoria del sujeto en crisis crea un espacio de eufemización contra el nefasto devenir y el tiempo. En el punto anterior señalamos los símbolos catamorfos como la irremediable caída del personaje, el tiempo era una constante que causaba angustia y abandono pues al final la muerte encontraba al sujeto en crisis. Por tanto, como lo mencionamos, los símbolos catamorfos, están en la teoría de Gilbert Durand en el régimen diurno. La memoria que tiene la función de crear un espacio de refugio para el personaje estaría dentro de la constelación del régimen nocturno. Explicaremos las características de este régimen y su relación con la memoria que en las novelas de Cruz Kronfly logran crear un espacio donde lo poético y la ensoñación logran por un momento brindar una salida y esperanza para el sujeto en crisis. 
El régimen nocturno tiene la principal función de eufemizar y transmutar los símbolos, de hacer que las calamidades del régimen diurno no se vean tan nefastas. Mientras en el régimen diurno imperaba la antítesis, en el nocturno los símbolos se invierten, la caída se transforma en descenso, en la misma noche se encuentra refugio. Al respecto Durand, en Las estructuras antropológicas de lo imaginario, plantea:

Frente a las caras del tiempo, por lo tanto, se dibuja otra actitud imaginativa, consistente en captar las fuerzas vitales del devenir, en exorcizar los ídolos mortíferos de Cronos, en transmutarlos en talismanes benéficos, en incorporar a la ineluctable movilidad del tiempo, finalmente, las tranquilizadoras figuras de constantes, de ciclos que en el propio seno del devenir parecen realizar un designio eterno. El antídoto del tiempo no será ya buscado en el nivel sobrehumano de la trascendencia y de la pureza de las esencias, sino en la tranquilizadora y cálida intimidad de la sustancia o de las constantes rítmicas que esconden fenómenos y accidentes. El régimen heroico de la antítesis va a ser remplazado por el régimen pleno del eufemismo (2004:199).

Es así, que en el eufemismo del régimen nocturno la caída encontrará un suave descenso. Es vital explicar que el símbolo puede cambiar de semanticidad, es decir, es polivalente y plurisignificativo, por tanto, aunque el arquetipo se mantenga, los esquemas varían y el símbolo, según de donde se interprete, puede significar la luz o la oscuridad, pues en su trayecto antropológico algunas veces invierte su semanticidad. En las novelas estudiadas la memoria tiene la función de eufemizar la calamidad del sujeto en crisis. Además de ser un artificio que utiliza el autor, crea un espacio donde el personaje evade la realidad y el presente que enfrenta. El tiempo, dinamizado por el régimen nocturno, parece detenerse para brindar un espacio de reposo al sujeto en crisis. En "El espacio forma a priori de la fantástica" de Las estructuras antropológicas de lo imaginario, Durand plantea el papel de la memoria dentro del eufemismo: "Muy lejos de estar a las órdenes del tiempo, la memoria permite un redoblamiento de los instantes, y un desdoblamiento del presente; da un espesor inusitado al flujo taciturno y fatal del devenir, y en las fluctuaciones del destino garantiza la supervivencia y la perpetuidad de una sustancia" (2004:409). Y es la memoria la que en las obras de Cruz Kronfly permite eufemizar la caída y garantizar un reposo para el personaje. El espacio eufemizante que crea la memoria será el lugar donde el personaje se refugia y se vitaliza. Respecto al espacio, el fenomenólogo de la imaginación afirma: “El espacio se 
convierte en la forma a priori ${ }^{6}$ del poder eufémico del pensamiento, es el lugar de las figuraciones porque es el símbolo operatorio del distanciamiento" (414). La cita describe el distanciamiento, es decir el lugar de la memoria para refugiar las calamidades de la caída del sujeto en crisis. El espacio en Gilbert Durand es una forma de la memoria, que dentro del régimen nocturno que estudiamos, crea una sensación de alivio ante la angustia y la muerte. Es necesario mencionar que Durand ubica la memoria y el espacio en su capítulo "Elementos para una fantástica trascendental” dentro de la inversión eufémica de los símbolos, y además brindan un consuelo a la calamidad humana, sobre ello el autor dice: "La función fantástica, por consiguiente, es función de esperanza" (420). La esperanza entonces también brinda una suerte de consuelo al sujeto en crisis, sin embargo, aunque la memoria cree un espacio para eufemizar la realidad de los personajes, la caída, que se transforma en lento descenso, no deja de producirse. Veamos ahora el papel de la memoria y el espacio en las novelas de Cruz Kronfly, ya que allí el sujeto en crisis olvida la vacuidad de su existencia.

En La obra del sueño la memoria trae las imágenes de tiempos olvidados. Crea espacios que escapan a la misma sustancia del tiempo. El régimen nocturno dinamiza el devenir. La obra empieza con las imágenes que tiene Genoveva, ella recuerda lo vivido con Leopoldo, con sus hijas, Alejandro, Mario, Salomón Náder y los demás personajes. Aunque en el primer capítulo de nuestra investigación señalamos como sujeto en crisis a Leopoldo, podríamos decir que Genoveva tampoco vive, sino que recuerda. La obra del sueño está construida sobre la memoria que crea espacios eufémicos contra la muerte. Genoveva nunca tiene una conciencia del presente, conmemora la muerte de Leopoldo angustiado por el fracaso de la modernidad. Salomón Náder, personaje de la obra que quiere casarse con Jimena, una hija de Genoveva y Leopoldo, invadido por las distantes imágenes y espacios se aleja. Desde el principio de la obra el autor señala: "Más allá en aquel paisaje de fotografía que mis ojos tienen delante de sí alcanzo a ver a Mario. (1984:1). Las primeras líneas de la novela señalan el espacio simbólico que va a vivir Genoveva. Ella escapa al

\footnotetext{
$6 \quad$ Las cursivas no son nuestras, pertenecen al autor.
} 
presente. A lo largo de la obra, la memoria elabora distintos espacios para el sujeto en crisis. Más adelante encontramos:

Mario pasa presuroso, una vez más, hacia el cuarto de mis hijas, llevando bajo el saco de su smoking un par de bananas maduras. Cierro mis ojos, simulando no haber visto aquel oprobio. Afuera, el mar continúa sonando como una memoria eterna que lava sus pies mientras canta letras de superficie. Mientras canta. Mientras canta sin reposo.

Cómo impedir, entonces, que el recuerdo de Leopoldo me asalte? Cómo evitar la evocación de su imagen en Dinamarca, un par de años antes de conocerle? $(14,15)$.

La cita señala el recuerdo de Leopoldo. Genoveva se encuentra en un espacio donde rememora las imágenes de un tiempo olvidado. El sujeto en crisis escapa al presente y al tiempo. Salomón Náder, personaje melancólico y triste también vive del espacio eufémico y burla las calamidades que enfrenta, el recuerdo de la infancia le hace feliz:

Ve, imagina estar mirando todavía a sus padres batiendo sus pañuelos blancos asomados a la puerta de aquella urgente despedida, y vuelve a percibir a sus hermanos, colocados delante de sus padres, como en una fotografía cuya nitidez resultara afectada por la tristeza y el pavor que alcanzaba a sentir. Recuerda, dentro del escenario memorioso de su boca, el sabor agridulce del último trozo de albaricoque que pudo probar antes de la partida [...] (25).

Es así que Salomón Náder contempla épocas anteriores donde vivió con su familia. La memoria, una vez más, tiene la función de crear espacios que hacen posible que el sujeto se refugie de los pesares que vive.

En La obra del sueño la memoria tiene un papel primordial: establecer el espacio para el sujeto en crisis. Desde el principio de la obra, como señalamos anteriormente, las imágenes del pasado vuelven para eufemizar el presente, el régimen nocturno se dinamiza.

Genoveva, igual que Salomón Náder, no vive, pues el recuerdo hace que vaya y venga de una forma discontinua, por tanto, los personajes tratan de escapar o exorcizar el tiempo. Analicemos ahora el papel de la memoria y el espacio en La ceniza del Libertador.

Bolívar, descrito en La ceniza del Libertador como un héroe marginal y derrotado, que va enfermo por el río Magdalena y desea recuperarse y obtener un pasaporte para de nuevo sentirse en el mundo, logra, por momentos atemporales, exorcizar las calamidades que la vida, la historia y La Gran Colombia le han impuesto. La memoria crea un espacio donde el 
Libertador encuentra calma. Su caída del poder y la gloria, gracias a la dinámica del régimen nocturno, se eufemiza; el destierro se transmuta en viaje. El sujeto en crisis en La ceniza del Libertador, logra entonces encontrar un lugar donde las imágenes pasadas, batallas vencidas y personas del pasado, vuelven para acoger a Bolívar y hacerlo vivir una suerte de ensoñación. La historia, que comienza con el inicio del viaje, muestra un Libertador abstraído y melancólico, que se pierde en la profundidad de su memoria. A lo largo del camino, el Libertador que tiene síntomas enfermizos, que en el segundo piso de la embarcación escucha un complot en su contra y pierde hasta su reputación de héroe, no le queda sino refugiarse en el espacio fantástico de la memoria; allí Bolívar olvida su enfermedad y los pesares que lo acompañan. En este espacio, que se resiste contra el destino fatal del Libertador, algunos personajes reviven. El Libertador logra refugiarse en un viaje onírico, en un viaje a las profundidades de su pasado. Veamos:

Delante de la puerta, Su Excelencia da vuelta a la cerradura y empuja. Un olor de aposento cerrado brota de inmediato. Polvo húmedo navegando en lo quieto de lo oscuro a solas. Y recordó aquellas alcobas cerradas de su casa de San Mateo, allá en Aragua, ocupadas de viejos muebles inservibles, telas deshechas y túmulos de papeles que al contacto con la luz despedían aquella especie de peluza picante a la nariz. Escucha a Hipólita estornudar, la percibe con un trapo de colores amarrado a su frente. Sobre un asiento de cuero observa su pequeña valija donde lleva para el viaje sus efectos más personales: camisas limpias, pantalones, ropa interior objetos de tocador, calcetines y el cristal casi vacío de una loción inglesa (1987:23).

La cita describe con detalles cuidadosos el espacio del sujeto en crisis. Es interesante observar como el narrador cambia de tiempo y nos inserta en un lugar que sólo conoce Bolívar, un lugar lejano que cambia por momentos el devenir del Libertador. La puerta de las primeras líneas que abre Bolívar es una parte de su memoria: "Delante de la puerta, Su Excelencia da vuelta a la cerradura y empuja. Un olor de aposento cerrado brota de inmediato. Polvo húmedo navegando en lo quieto de lo oscuro a solas. Y recordó [...]" (23). Hipólita, la esclava negra que lo cuidó cuando era niño, reaparece para crear un símbolo maternal. Es así que el espacio, que aplaza las calamidades de la existencia, logra que el sujeto en crisis se resigne o no se haga tan dura su caída, personas que el Libertador conoció regresan para acompañarlo en su crisis. La enfermedad de Bolívar y su calamidad parece desaparecer bajo la función eufémica del espacio, por ello el Libertador a lo largo de 
su viaje ve rostros e imágenes que fueron significativas para él. La linealidad del presente se invierte con los recuerdos de Bolívar. Es así que en el espacio del régimen nocturno, la enfermedad del Libertador se calma, la angustia del devenir se detiene. El sujeto en crisis que evade la realidad y no tiene conciencia de su existencia en el presente, encuentra en la memoria una suerte de reserva contra el tiempo que lo consume y el vértigo que le produce la caída del poder y el término de la gloria.

Indiscutiblemente, de las tres novelas estudiadas, La caravana de Gardel es la que mejor muestra la función de la memoria y el espacio. Arturo Rendón, sujeto en crisis, personaje melancólico que emprende un recorrido quijotesco en busca de un jirón o algún objeto de Gardel, vive incesantemente de las imágenes que el espacio de la memoria crea. El arriero, que escucha tangos que acompañan la sensibilidad y la desesperanza del hombre moderno, nunca ha dejado de vivir el momento en que transportó el cadáver del cantante argentino. Los sucesos del primer viaje a lomo de mula, guían, después de quince años, un segundo viaje. En esta obra el pasado alimenta el presente. El sujeto en crisis desilusionado en el presente vuelve sobre sus pasos en busca del tiempo perdido. En la novela se lee:

Entonces repasó de nuevo aquello que tanto había visto y vuelto a ver durante estos últimos quince años:

Heriberto Franco y él se habían dedicado a sujetar los maderos de la barbacoa a los lomos de los dos animales elegidos, dejando entre uno y otro la distancia suficiente como para acomodar en el centro el féretro, lo más cómodamente. Adelante debía marchar Bolívar, un mulo diestro en abismos y en encarar sombras impenetrables, que se conocía de memoria el camino y que era zaino, de buena alzada y de seguro paso" (1998: 28,29).

Arturo Rendón vive en un espacio pasado que la memoria construye. En todo momento está viviendo imágenes anteriores. El presente del sujeto en crisis es desesperanzador, sin embargo, el régimen nocturno de la imagen, le da cierto ánimo en la calamidad, las figuras de la noche se invierten en cálidas. Es interesante señalar que aunque el primer viaje que hace Rendón es a lomo de mula como la muestra la cita, Colombia era más rural y segura, el arriero se sentía feliz. Después de quince años, cuando Arturo Rendón emprende de nuevo el viaje y ya no lo realiza en mula sino en una berlina, Colombia es otra, el urbanismo que trajo consigo la exclusión de la profesión del arriero ayuda a generar la crisis del sujeto. Esta vez Arturo Rendón, inconscientemente, siente el peso de la 
marginalidad y la desesperanza, solo la memoria brinda una escafandra al sujeto en crisis. El arriero nunca se creyó del tiempo en que vivía, el viaje que hizo lo ancló al pasado. Para aclarar nuestra idea veamos lo siguiente: "Nunca antes se había sentido más solo y humillado. Ahora tenía claro que su Gata pertenecía a otro tiempo, tal vez al presente sin historia, donde los símbolos daban risa y solo los signos sin contexto tenían prestigio y eran capaces de representar la lógica del nuevo mundo, del que él se sentía tan solo un transeúnte" (210). Lo mencionado muestra que Arturo estaba anclado al tiempo de la Colombia rural, al pasado y el espacio de un tiempo que no olvidaba. Se señala además, como lo mencionamos en el primer capítulo, que Arturo Rendón, vive en la desesperanza del tiempo moderno, que aunque a Colombia llega en una etapa tardía, se refracta de manera clara en la actitud del arriero sobre el presente. Lo único que tuvo fue la memoria de un cantante que siempre lo acompañó y le brindó un espacio donde Rendón volvió a vivir. Finalmente el régimen nocturno de la imagen ayuda a eufemizar la terrible caída del sujeto en crisis. Aunque el arriero no pudo recuperar ninguna pertenencia de Gardel, el espacio eufémico hizo que viviera de nuevo su primer viaje, por tanto, la caída se transforma en descenso y el personaje, a pesar de lo malo que pueda ocurrir, exorciza las calamidades que debe enfrentar.

Al término de este segundo capítulo queremos resumir lo siguiente: el sujeto en crisis en las tres novelas estudiadas: La obra del sueño, La ceniza del Libertador y La caravana de Gardel, son personajes melancólicos que evaden la realidad y caen al abismo de sus angustias, de sus miedos, incluso los tres personajes: Leopoldo, Simón Bolívar y Arturo Rendón encuentran la muerte. El símbolo de la caída lo interpretamos desde la teoría de Gilbert Durand, donde el autor postula los símbolos catamorfos, que pertenecen a la constelación del régimen diurno de la imagen. En este régimen el tiempo devora al ser humano, el Yo tiene una conciencia sobre la irremediable fugacidad de la existencia. El sujeto en crisis que plantemos cae de su trono de gloria, es desterrado de sus tierras, perdió algo que no volverá a encontrar y siente miedo sobre su devenir. Luego, en el segundo apartado: La memoria, el escape del sujeto en crisis argumentamos que el espacio creado por la memoria eufemiza la irremediable caída. Este espacio simbólico, que es el único 
lugar donde el sujeto en crisis olvida sus pesares y vuelve sobre aquello que alimenta su presente, ayuda a eufemizar la angustiosa caída. Para ello, basados también en Durand, tomamos como referencia el régimen nocturno de la imagen, donde los valores se invierten y se trasmutan. La caída entonces se transforma en suave descenso que hace que por momentos la desgracia no parezca tan terrible. El tiempo creado por la memoria hace que el sujeto en este espacio no sienta las horas, se crea una suerte de atemporalidad. Es necesario mencionar que esto ocurre bajo el régimen nocturno que tiene la función de eufemizar los símbolos.

El símbolo en Gilbert Durand puede cambiar de semanticidad, según su trayecto antropológico y la cultura donde se encuentre inmerso. En nuestra investigación observamos bajo el régimen diurno la caída y el tiempo que consume al sujeto en crisis. Bajo el régimen nocturno la caída se transmutó en un suave descenso, donde la memoria y el espacio crearon un lugar para que el sujeto en crisis exorcizara los ídolos mortíferos del tiempo. Por tanto, el régimen diurno con símbolos de la caída y el régimen nocturno con espacios de reposo contra el tiempo, fueron fundamentales para comprender que aunque el sujeto en crisis no tiene una conciencia absoluta de su presente, encuentra en la memoria un lugar donde el pasado alimenta un ideal fallido. Antes de terminar quisiéramos mencionar que en La obra sueño, tomamos como referente a Genoveva y Salomón Náder porque el hilo conductor de la obra se centra en la memoria y sucesos de estos personajes. Así pues la caída y la memoria son categorías que constituyen el sujeto en crisis que planteamos en esta investigación.

El viaje y el agua, elementos comunes de las tres novelas, son fundamentales para comprender otros elemento que acompañan al sujeto en crisis; ahondaremos entonces en estas imágenes que se develan en la profundidad de lo simbólico. 


\section{El viaje hacia la muerte del sujeto en crisis y el agua de Caronte}

La muerte es un viaje y el viaje es una muerte. Fabio Martínez. El viajero y la memoria.

El viaje del sujeto en crisis, en las novelas de Fernando Cruz Kronfly, simboliza el desprendimiento del ser y la negación de la conciencia. Se viaja para olvidar las penurias de la vida. El personaje principal es desterrado o se desplaza para tratar de hallarse, emprende el viaje y la muerte lo cobija en su última aventura. El agua, elemento melancólico y femenino lo hace naufragar en la complejidad de la existencia. La muerte del personaje en crisis es inevitable. La caída que vimos en el capítulo anterior llega a su fin. La memoria, encargada de eufemizar las calamidades humanas con imágenes de tiempos olvidados, concluye con el final del sujeto en crisis. El personaje principal en las novelas de Cruz Kronfly emprende un viaje que será el último de una existencia negada, que solo tuvo valor en el recuerdo. El elemento acuático es fundamental para comprender la naturaleza de la melancolía, que según el fenomenólogo francés Gaston Bachelard está relacionada con el sujeto. El teórico de los cuatro elementos, discípulo confeso de Carl Gustav Jung, estructura la imaginación de una forma poética. Los cuatro elementos trabajados por el filósofo griego Empédocles: aire, fuego, agua y tierra, son retomados por el fenomenólogo, no para explicar el origen del mundo, sino para ahondar simbólicamente en cuatro elementos que encuentran su esencia en la potencia de la imagen poética. En El agua y los sueños Bachelard describe su función poetizante: "Siempre vuelvo a sentir la misma melancolía ante las aguas dormidas, una melancolía muy especial que tiene el color de una charca en un bosque húmedo, una melancolía sin opresión, soñadora, lenta, calma” (2003:16). Y esa melancolía acuática es la que guía el camino del sujeto en crisis en las novelas y algunos cuentos del escritor vallecaucano. 
El agua de la melancolía que transporta al viajero se encuentra latente en Cruz Kronfly y parece llevar consigo el tiempo y el final de la vida. En su cuento: "Las enmiendas como curaciones en el prójimo", publicado por Harold Kremer en Antología del cuento vallecaucano, un anciano, un poco enfermo, recuerda sus amores y narra algunas vivencias de las mujeres que amó. Lo importante del cuento es que el agua y el viaje acompañan al personaje en su memoria, como si sobre las aguas se llevara también el fin de la existencia. El cuento, en la voz del narrador personaje dice:

En este caso, he pensado que en el fondo de todo existe para ellos un hipotético naufragio que los obliga a hablar de sus asuntos más interiores, sin que nada interese de verdad a nadie y quizás por la posibilidad de que esa sea la última vez que se conversa sobre las cosas, como si el mar fuese un dios inmenso y cada pasajero fuera un representante del mar en cubierta (1992:81-82).

Podemos ver con claridad como convergen el viaje y el agua, que en las novelas estudiadas van de la mano, porque nuestro sujeto en crisis navega hacia la fatalidad. En la interpretación del elemento acuático en las obras de Cruz Kronfly parece ser que el personaje principal es conducido por la melancolía, la derrota y la carga existencial que le produce la sensación de abandono de la época en que se encuentra. En La obra del sueño, Leopoldo viaja a lomo de mula en un baúl. Naufraga de forma simbólica en la complejidad de la existencia, en el mar infinito de la nada; Genoveva, la mujer de Leopoldo que comienza el relato a través de su memoria, se sumerge en el recuerdo, viaja hacia el pasado. En La ceniza del Libertador, Bolívar es conducido por el río Magdalena que lo transporta y parece refractar sus pesares y su derrota de héroe desterrado y marginal. Es conveniente señalar en este apartado el texto de Alfonso Vargas Franco: "La desesperanza y la muerte en la novela La ceniza del Libertador de Fernando Cruz Kronfly" publicado por la revista Poligramas N. 21 de 2004 donde el autor menciona también el carácter del agua, al respecto dice: "La mar se convierte en una imagen poética de la muerte [...]" (173). En este sentido dialogamos con el autor y observaremos como navega nuestro sujeto en crisis. En La caravana de Gardel, el agua se trasmuta en espejo, que según Gilbert Durand también es un espejo que refracta la melancolía e incita a la muerte. Recordemos el ahogamiento del personaje mitológico Narciso que se enamora de su imagen al observar en el estanque su belleza y decide sumergirse en el agua de la muerte. El personaje principal, Arturo Rendón, 
observa en su propio rostro: la desesperanza; trata de reconocerse en su imagen proyectada y después del fracaso al intentar recuperar alguna prenda de Carlos Gardel encuentra la muerte. Interpretaremos entones el significado del viaje y el agua de la melancolía que también es la misma que conduce a Caronte porque sobre ella navegan los muertos.

\subsection{El viaje hacia la muerte}

El sujeto en crisis realiza el viaje y naufraga en las corrientes de la existencia. En el viaje trata de reconocerse y hallar algo de su pasado que lo ayude a existir, pero en su lugar encuentra la muerte que lo espera para librarlo de sus pesares. El primer libro de viaje que se escribe en occidente es La Odisea, en ella, Ulises lucha por regresar a su tierra natal Ítaca. La epopeya homérica muestra la transformación del héroe a lo largo de la obra. En la modernidad, la novela exhibe el decaimiento y el deambular del ser humano en una sociedad que no le ofrece asilo, donde nadie es de ninguna parte. A pesar de que en las obras de Cruz Kronfly el personaje principal se desplaza, nunca encontrará un lugar que le brinde lo que necesita, pues la modernidad, con todo su aparato ideológico margina a los que no están atados a ella, solo el tango acompaña el destrozo del hombre moderno en su

peregrinaje por el mundo. Es pertinente señalar que la novela de viaje busca una identidad que los sujetos en crisis no encuentran. Fabio Martínez, autor vallecaucano y estudioso sobre la literatura de viaje en Colombia, en su obra El viajero y la memoria señala "La novela de viaje en el continente correrá a lo largo del siglo XX preguntándose sobre los problemas del exotismo, la identidad y la alteridad" (2005:13). Los personajes del autor vallecaucano salen a la búsqueda de esa identidad que los haga existir, que los reafirme en el mundo. Leopoldo en la Obra del sueño, se libra de la muerte al emprender el viaje pero la violencia que atormenta al país y el desamparo del hombre moderno en la sociedad del momento lo seguirá a donde quiera que vaya. Bolívar en La ceniza del Libertador, emprende el viaje por el río Magdalena y conserva la esperanza de obtener un pasaporte, un permiso que le permita viajar por las tierras que liberó y autoafirmarse como el Libertador de cinco repúblicas. Arturo Rendón en La caravana de Gardel, parte para encontrar las 
prendas del cantautor argentino Carlos Gardel, sin embargo su viaje es una excusa fallida para recordar algo de sí mismo. Por tanto la identidad y la alteridad no serán encontradas por nuestro sujeto en crisis.

En el viaje, el sujeto en crisis se desprende o se despide del presente. La muerte es su última salida o la aventura inexplorada. Es pertinente mencionar, antes de profundizar en el viaje hacia la muerte del sujeto en crisis, algunas novelas colombianas de viaje que han sido significativas y que según Fabio Martínez, inauguran una literatura que busca explorar los lugares inhóspitos de Colombia y del ser humano. El autor vallecaucano señala:

[...] Es en esta dinámica de construcción imaginaria de un país, que se producirá cinco años más tarde, Cuatro años a bordo de mí mismo, de Eduardo Zalamea Borda, y con ella surgirá la novela iniciática en el país, que luego, en las postrimerías del siglo XX, se verá representada en El buen salvaje de Eduardo Caballero Calderón, en Fugas o Biografía de un embustero de Óscar Collazos, y El viaje triunfal de Eduardo García Aguilar, entre otras (14).

La cita muestra las novelas iniciáticas que comienzan a describir el viaje en Colombia y, según Fabio Martínez, la exuberancia de la naturaleza que impone al narrador. Ahora bien, las obras de Cruz Kronfly exhiben un sujeto en crisis que va hacia la muerte, que navega en la irremediable desconsolación humana en que se encuentran los personajes. En La obra del sueño, Leopoldo es obligado a viajar. Su padre lo introduce en un baúl al lomo de una mula llamada Polvo de los caminos y el personaje se despide de su madre, al hacerlo se percibe su tristeza. En la obra se menciona: "Me marcharé a Jericó y me ocultaré entre las ruinas heladas. Pero por más que logre sobrevivir, la violencia continuará siendo la única alternativa del destino de muchos nosotros" (1984:32). El joven que inicia el viaje tiene una visión amplia del mundo. Leopoldo sabe que no podrá escapar de la violencia que lo asedia. El sujeto en crisis parte entonces en busca de algún consuelo. Sin embargo, al partir hay un desprendimiento de las cosas que quiso, de sus sueños e ideales. Pero existe también una transformación del personaje que comprende el fracaso de la Modernidad. Genoveva, la mujer de Leopoldo, que narra la historia, en el momento en que muere su marido menciona: "Y escuché, por última vez, su estertóreo grito de despedida: -Adiós, hijueputas!!! Balbuciente, agregó: -Me muero, pero ahí les dejo la guerra. Espero que puedan gozar de ella. Y se hundió" (139). Es así que después del viaje, el sujeto en crisis encuentra la 
muerte. En la cita se puede ver que Leopoldo se despide del mundo violento donde fue un ser incomprendido, un visionario que conocía la sociedad que lo rodeaba. Es importante mencionar que el viaje de Leopoldo anuncia sus últimos días, como si partir de alguna forma fuera despedirse de la vida, porque el personaje jamás volverá sobre los pasos recorridos. El sujeto en crisis cumple entonces su viaje hacia la muerte.

Simón Bolívar en La ceniza del Libertador, emprende su viaje debido al destierro que le imponen. En el recorrido el héroe se muestra marginal y melancólico, mediante el dolor y la ausencia de la gloria Cruz Kronfly humaniza al Libertador. A lo largo del viaje, Bolívar tiene visiones oníricas que confunden su realidad, quizá porque en el camino decae el sujeto en crisis. El autor de El viajero y la memoria menciona sobre la obra: "Por su parte, La ceniza del Libertador maneja una doble estructura entre el mundo real y el mundo fantástico, que opera en la mente trastornada del viajero" (2005:94). Y son esos dos mundos que menciona la cita los que hacen pensar en el pasado y el presente, en la vida y la muerte, en la quietud y el viaje. Fabio Martínez matiza el carácter del viaje al relacionarlo de manera directa con el infierno, el autor comienza con una pregunta que será válida para nuestra investigación: “¿A qué nos remite la figura del viajero infernal? Como en la tragedia latina, la novela de viaje colombiana, con su figura del viajero infernal, nos remite a la imagen de la muerte" (209). Por tanto, la figura de Bolívar en su último viaje terminará con sus días. Es necesario mencionar que a lo largo del camino, el Libertador va perdiendo lo que siempre lo enalteció: su reputación de héroe. A medida que Bolívar avanza en el Champán, nombre que el autor utiliza para referirse a una pequeña embarcación, y arriban a algunos puertos, las personas le gritan tirano y lo insultan, veamos: "El hombre que ustedes ven ahora no es un héroe sino un vergonzoso nudo de ambiciones" (329). Si pensamos en lo marginal, el decaimiento y el sufrimiento de Bolívar por la enfermedad que lo agobia, podríamos validar entonces lo señalado en la anterior cita sobre la figura del viajero infernal, ya que Bolívar en su último viaje, vive la desgracia humana de la miseria y el rechazo del pueblo que él mismo liberó, sufre por lo que hizo o dejó de hacer. Finalmente Cruz Kronfly crea una figura estética de la muerte que señala el fin de Bolívar. En la novela se lee: 
El sapo de la muerte trepa el asiento, salpica con su leche los quemados ladrillos del piso, la ropa que cuelga en el espaldar. Salta a la cama, busca el calor de las sábanas, desaparece. Su excelencia ilumina sus ojos por última vez, ni él mismo sabe qué es aquello que percibe en medio de la niebla que de repente ciega el aposento (340).

Es así que el Libertador llega al término de sus días. El viaje del sujeto en crisis es consumado en la muerte.

La caravana de Gardel (1998), última novela publicada de las tres estudiadas, muestra de forma más directa el viaje hacia la muerte del sujeto en crisis. Nuestro protagonista, Arturo Rendón, viaja para encontrarse a sí mismo y desaparece buscando su pasado. El sujeto en crisis no vive en el presente, no tiene una relación concomitante que lo haga existir. La obra se divide en dos estructuras narrativas: la primera es el presente de Arturo Rendón, donde el personaje empieza el viaje para tratar de hallar las pertenencias del cantante argentino Carlos Gardel, la segunda es el recuerdo del primer viaje que hizo el arriero a lomo de mula alrededor de los años treinta que el autor inserta en el relato de manera prolija. Ambas historias: pasado y presente están unidas por el epicentro del viaje. En el pasado el joven arriero lleva el cadáver del cantautor del tango, tiene la misión de llevar el cuerpo del cantante favorito de Colombia. Cuando Rendón en compañía de Heriberto Franco y Gómez Tirado, avanzan por las montañas de Colombia se percibe la tristeza de la ausencia que ha dejado el cantor de tango y la desesperanza que arrastra consigo la Modernidad. Al final el arriero entrega el cuerpo. En la novela se lee:

En Buenaventura perdió muy pronto el rumbo del féretro, y estuvo en la bahía despidiéndose de un buque que no era. Durante las noches que siguieron se vio envuelto en peleas inexplicables, con negros corpulentos que se reían de su tristeza y que bailaban todo el día no sólo con sus pies sino con ambos ojos. Y se perdió en solitario durante muchas semanas que se fueron transformando no sólo en meses sino en años (215).

La cita es vital para comprender que en el primer viaje Arturo Rendón abandona el mundo, se presenta una muerte simbólica. Cuando el arriero, quince años después, decide emprender de nuevo el camino, la muerte acoge en sus brazos al viajero derrotado que no ha podido encontrar a Heriberto Franco y mucho menos alguna prenda de Gardel. El mismo Arturo Rendón piensa en sus últimos días: "Y pensó en la muerte, como el más grande y 
espléndido de todos los misterios, y volvió a ver a su Gardel, reclinado en la barbacoa, descansando en su cómoda caja recubierta de cera y a veces con flores silvestres que caían de las ramas y mantos de hojarasca seca" (133). La muerte se presenta entonces como la última aventura del arriero. Al final Arturo Rendón sabe que Heriberto Franco ha muerto y que la misión de recuperar alguna prenda o jirón de Carlos Gardel es imposible, el arriero siente el peso del mundo que lo abruma. El sujeto en crisis desaparece en el olvido, su Yo no tiene una conciencia del presente y de lo que vive. Arturo Rendón aborda entonces una berlina con el ánimo de regresar, sin embargo, su retorno es negado. En la novela se lee: "Después de pasar por el rancherío del otro día, ante cuyos niños hinchados y desnudos, perros y cerdos Arturo Rendón tuvo por primera vez el presentimiento de su muerte, la berlina tomó su descenso hacia el lecho del río" (224). La berlina termina en un accidente trágico. El sujeto en crisis encuentra la muerte, el viaje culmina en el irremediable fin de la vida humana. Es así, que nuestros personajes emprenden la marcha y nunca regresan, en las novelas de Cruz Kronfly no hay un retorno, el regreso a Ítaca que hace Ulises en La Odisea homérica es imposible en el universo novelesco del escritor vallecaucano. Quizá porque en la novela el mundo perfecto no existe y la Modernidad no tiene dioses. El sujeto en crisis viaja al encuentro con la muerte, tal vez ella sea la única capaz de librarlo del peso que lo abruma.

El viaje hacia la muerte del sujeto en crisis es sobre el agua de Caronte. La figura del barquero mitológico que transportaba las almas al Hades reaparece. Interpretaremos entonces el aspecto melancólico del agua que refracta las penas del sujeto en crisis y lo conduce a la muerte

\subsection{El agua de la melancolía}

El agua de la melancolía acompaña al viajero de las novelas de Cruz Kronfly. El sujeto en crisis navega sobre su irremediable desamparo. No tiene un piso fijo, pues en el 
movimiento y la inestabilidad busca lo imposible. Sabe que es su última aventura.

Leopoldo a donde vaya no estará firme en la sociedad que lo rodea; Bolívar avanza sobre el río Magdalena que lo conduce hasta el fin de sus días, siempre espera un pasaporte y un permiso que nunca llegarán. Arturo Rendón se mira constantemente en un espejo, como si quiera reconocerse y hallar algo en él mismo. El espejo, en la constelación del pensador de lo imaginario, Gilbert Durand, es agua que transcurre como el tiempo y refracta la melancolía y la tristeza. Veamos entonces el carácter nostálgico del agua que acompaña al sujeto en crisis y que también es la nostalgia de Caronte, pues los que van al reino de la muerte navegan sobre ella.

La melancolía conduce al sujeto en crisis. Gaston Bachelard, en El agua y los sueños, menciona un aspecto clave sobre el agua que acompaña a nuestros personajes novelescos. Al respecto señala:

Así el adiós al borde del mar es a la vez el más desgarrador y el más literario de los adioses. Su poesía explota un viejo fondo de sueño y heroísmo. Despierta sin duda en nosotros los ecos más dolorosos. Todo un lado de nuestra alma nocturna se explica por el mito de la muerte concebida como una partida en el agua (2004:118).

Y es el dolor y la frustración de los sueños perdidos y los ideales no alcanzados los que sobre el agua llevan la tristeza de los personajes de nuestras novelas. Pues la metáfora del tiempo de Heráclito donde nadie se baña dos veces en el mismo río, trae consigo un aire de nostalgia, pues las oportunidades se han perdido y no volverán.

En las novelas de Fernando Cruz Kronfly emerge alrededor del sujeto en crisis el viaje y el agua de la melancolía que conduce a la muerte. Es relevante señalar que el planteamiento de la melancolía de las aguas pertenece a Bachelard, quien menciona: "Estamos ante el íntimo juego de una ensoñación que enlaza a la luna y al río y que sigue su historia a lo largo de la corriente. Tal ensoñación realiza en toda la fuerza de su término la melancolía de la noche y del río" (138). Aunque en las obras que estamos interpretando la luna y la noche no son elementos constantes, el agua arrastra al sujeto en crisis. La imagen de Caronte, el personaje de mitología griega que conducía las almas de los muertos sobre el río Aqueronte, que según el diccionario mitológico de André Bonnard en Los Dioses de Grecia (2008), traducción realizada por Edgar Bastidas, es uno de los ríos del infierno, 
vuelve a cobrar significado; pues nuestro sujeto en crisis también navega hacia el fin de sus días. Es interesante señalar que en el viaje que emprende Dante en La divina comedia, encuentra al barquero en el infierno y su maestro Virgilio señala la cantidad de almas en pena que debe pasar Caronte por el río, el autor italiano describe:
Y están ansiosos de cruzar el río, pues la justicia santa les empuja, y así el temor se transforma en deseo «Aquí no cruza nunca un alma justa, por lo cual si Carón de ti se enoja, comprenderás qué cosa significa.» Y dicho esto, la región oscura tembló con fuerza tal, que del espanto la frente de sudor aún se me baña (1967:12).

De la cita quisiéramos señalar el aspecto sombrío de las almas y la figura de Caronte que es el encargado de conducirlas. Nuestro sujeto en crisis navegará en el agua de la melancolía que refractará sus pesares, sus recuerdos, el tiempo ido y finalmente el encuentro con la muerte, que igual que las almas que conduce Caronte, esperan el término del sufrimiento o el olvido total de sus cuerpos en la existencia que enfrentan.

El agua de la melancolía que pensamos acompaña al sujeto en crisis, se percibe de forma literal en La ceniza del Libertador, sin embargo en sus otras dos novelas se presentan de forma simbólica, pasemos pues a tratar de hallar ese elemento acuático que conduce al sujeto en crisis y termina en la fatalidad de la muerte.

En La obra del sueño la figura del agua de la melancolía se presenta desde el principio. La novela, como lo mencionamos en el primer capítulo de la presente investigación, está narrada desde un narrador en primera persona que es Genoveva, la mujer de Leopoldo, y desde un narrador omnisciente que va enmarcando los sucesos de los personajes. Los acontecimientos, como también lo dijimos, ocurren a través de la memoria y el agua de la melancolía, del mar donde naufraga el sujeto en crisis, veamos:

Mario pasa presuroso, una vez más, hacia el cuarto de mis hijas, llevando bajo el saco de su smoking un par de bananas maduras. Cierro mis ojos, simulando no haber visto aquel oprobio. Afuera, el mar continúa sonando como una memoria eterna que lava sus pies mientras canta letras de superficie. Mientras canta sin reposo. 
Cómo impedir, entonces, que el recuerdo de Leopoldo me asalte? Cómo evitar la evocación de su imagen en Dinamarca, un par de años antes de conocerle? (1984:14-15).

Es así, que desde el principio la figura del mar, como lo muestra la cita, hace navegar en el recuerdo a Genoveva, desde allí comienza el viaje del sujeto en crisis. El mar en sus corrientes trae el recuerdo de Leopoldo, y este naufragará en la complejidad de la existencia.

En La ceniza del Libertador, el agua de la melancolía que acompaña el deambular y el peso del mundo de nuestros personajes estudiados se presenta de forma literal. Bolívar emprende su viaje sobre el río Magdalena y parece que navegara en la barca de Caronte, pues cuando llega a Santa Marta la muerte vendrá a recogerlo. Sin embargo, es sobre el agua que recuerda sus hazañas y sus fracasos, sobre ella quiere vomitar y desprenderse de la realidad miserable que ahora debido a las circunstancias debe enfrentar. Bachelard, en El agua y los sueños también resalta un aspecto clave del agua y de la figura del viajero que va sobre ella: "Desaparecer en el agua profunda o desaparecer en un horizonte lejano, asociarse a la profundidad o a la infinitud; tal es el destino humano que busca su imagen en el destino del agua" (2003:25). Y la gloria de Bolívar a lo largo de la obra desaparecerá, quizá porque la muerte solo acepta al sujeto en crisis como humano, como un ser elemental que cumple un ciclo y al final todos somos iguales en el irremediable fin del hombre. En la obra Bolívar desea de nuevo el agua del Orinoco e intuye que navega hacia la muerte:

En lo que lleva de viaje Su excelencia no ha podido tomar un baño en aguas profundas como a él le place. Aguas de cuerpo entero. A cambio, sólo ha podido asearse a desgano utilizando una toalla mojada que arrastra en su piel, en sus sitios declives. Fina ceremonia de trapos, de perfumes tibios dentro de la letrina. Cómo añora el Orinoco, sus aguas de profundidad invisible. Aquel Orinoco, el más lindo de todos los ríos que sus ojos vieron. Morir, dejar para siempre aquellos ríos, alejarse de ellos en un viaje hacia las tinieblas es algo que lo conmueve, que lo confunde:

-Yo no tengo corazón para la muerte, no me gusta, no la entiendo, ¡carajo! (1987:266).

Podemos observar entonces el aspecto del agua y su relación con la muerte. El agua parece atraer a Bolívar, sin embargo, el Libertador siente la bruma del fin. Porque al final, cuando su viaje termine, además de que su gloria como salvador de Sur América terminará, encontrará la muerte. 
En su obra El agua y los sueños Bachelard menciona el aspecto del héroe viajero que sería importante resaltar: "El héroe del mar es un héroe de la muerte. El primer marino es el primer hombre vivo que fue tan valiente como un muerto" (115). Bolívar, como lo muestra la novela de Cruz Kronfly, es un héroe derrotado, que se humaniza mediante el dolor y el sufrimiento del cuerpo en decadencia. A pesar de ello, desde nuestra lectura particular, sigue siendo el héroe, solo que esta vez no se enaltece ni se vanagloria, sino que se enseña como un hombre imperfecto. En la obra Bolívar viaja y el agua de la melancolía lo acompaña hasta el final. Cuando su embarcación arriba al puerto se puede observar el papel preponderante del agua y de la muerte en el viajero:

Los de la caravela Niña también vieron otras señales de tierra y un palillo cargado de escaramojos. Con estas señales respiraron y alegráronse todos

Todos se agolpan en la ventana:

-Llegamos, ¿de verdad llegamos?

-Sí, miren, esa es la mar, ¡oíganla, oíganla!

La mar de la muerte.

Desde su lecho de ciego un papel ejerce el poder, resopla esponjado (325).

Podemos observar entonces como el agua relacionada también con la muerte, porque conduce al irremediable fin de Bolívar, es latente y relevante en la novela como símbolo de la melancolía y la sensación de derrota que acompaña al sujeto en crisis.

La caravana de Gardel muestra de forma distinta el aspecto melancólico del agua, pasemos pues a interpretar su manifestación en el espejo, que también ahoga en el vacío existencial a nuestro sujeto en crisis: Arturo Rendón.

Gilbert Durand, en Las estructuras antropológicas del imaginario, realiza un isomorfismo entre el agua y el espejo. El autor plantea, desarrollando una idea de Carl Jung en Símbolos de transformación (1993), que el espejo también es materia líquida y cumple la función del agua en cuanto refracta la imagen, al respecto refiere: "Pero ese simbolismo del espejo nos aleja suavemente de aquel viejo rey ciego para introducir una nueva variación nictomorfa: el agua, al mismo tiempo que bebida, fue el primer espejo estancado y oscuro" (2004:99). Existe entonces una relación directa entre el agua y el espejo, con lo nictormorfo se refiere Durand a los símbolos de la noche. Sobre la muerte y su correspondencia con el agua, el 
autor aclara el aspecto que también pretendemos mostrar sobre la melancolía, sobre ello dice: "El agua se convierte incluso en una directa invitación a morir: de estinfálica que era, "se Ofeliza". Ahora vamos a detenernos un poco en las diferentes fantásticas de esta gran epifanía de la muerte" (100). Es así que esa invitación a morir es la que seduce al sujeto en crisis y quizá el único camino después de un largo viaje.

En La caravana de Gardel, Arturo Rendón, nuestro sujeto en crisis, se siente seducido por su propia imagen y parece que en él renaciera la figura de Narciso, solo que esta vez no muere en el estanque, sin embargo su rostro lo embriaga continuamente. Es necesario mencionar que el arriero Arturo Rendón, además de ser un poco narcisista es melancólico, en su recorrido el tango acompaña su sensibilidad y la tristeza que lo abruma.

Continuamente el arriero se mira en el espejo, como si tratara de encontrarse. El agua de la melancolía, trasmutada en el vidrio, lo ayuda para alentarlo a continuar en su viaje. En la obra se evidencia:

$\mathrm{Al}$ rato, Arturo Rendón ya estaba tirado sobre el camastro. Se había despojado de sus botas y no hacía sino pensar e ir a darse un baño, perturbado como se encontraba por el efecto de las últimas visiones. Ya había ido a consultar con el espejo que colgaba sobre la mesa donde fulgía una jofaina esmaltada adornada con figuras de colibríes y que ofrecía la forma de una joya antigua, y había comprobado que a pesar de todo aún seguía siendo casi el mismo de ayer, muy parecido al que había estado sentado en lo de María Bilbao tomándose unas cervezas hacía apenas cuatro horas (1998:38).

Es así que Arturo Rendón mira su rostro reflejado para reconocerse. La imagen del espejo, como mencionamos anteriormente, también es agua y esta lleva consigo el tiempo. Cada vez que Rendón se observa, piensa en los años de su juventud cuando llevó a lomo de mula el cadáver de Gardel y se da ánimo para continuar el viaje. La obra muestra: "Y entonces abrió sus ojos y agarró su sombrero se puso de pie y fue de nuevo hasta el espejo y se lo puso y sonrió ante sí mismo, cínicamente, como si estuviera empeñado en vivir una impostura" (118). Y la impostura es saber que no tiene una conciencia del presente, su relación es con un pasado perdido que no volverá.

El agua y el tiempo están asociados y se complementan en las novelas de Cruz Kronfly. El tiempo simbólicamente es agua que fluye como el río interminable de Heráclito. Gilbert Durand estudiando el elemento acuático refiere: "El agua que corre es amarga invitación al 
viaje sin regreso: uno nunca se baña dos veces en el mismo río, y éstos nunca remontan a su fuente. El agua que corre es la figura de lo irrevocable" (2004:100). En La obra del sueño el agua que mostramos transporta a Genoveva al recuerdo y la hace naufragar en la memoria. El tiempo pasa como el agua. En La ceniza del Libertador, el tiempo lleva sobre sus aguas a Bolívar. La obra muestra con claridad que la vida del Libertador se agota. En La caravana de Gardel, el agua que es el espejo metamorfoseado, lleva a Arturo Rendón sobre sus aguas. Sólo que aquí el arriero no navega literalmente, lo hace mediante el espejo que lo conduce a sus últimos días.

Tratamos de interpretar a lo largo del presente capítulo que el viaje, como símbolo relevante, en las novelas de Fernando Cruz Kronfly representa el final y la muerte del sujeto en crisis. Un sujeto en crisis que, como lo vimos en el segundo capítulo, escapa al presente y se refugia en la memoria. El sentido del viaje tiene como último fin liberar de la crisis al sujeto, ya que este no puede conseguir lo que desea y sufre en la existencia que soporta. Observamos con Fabio Martínez en El viajero y la memoria que el sentido del viaje busca encontrar la identidad, sin embargo, el personaje en Cruz Kronfly no la encuentra, si la tuvo fue en el pasado. El agua en La obra del sueño, La ceniza del Libertador y La caravana de Gardel, simboliza la melancolía y el tiempo que se escapa para el personaje. En La caravana de Gardel, el espejo es materia líquida que refracta la pesadumbre y el peso del mundo que sobre lleva Arturo Rendón en sus espaldas debido al fracaso de la Modernidad, que es la época de la desesperanza y del nihilismo. El elemento líquido, como lo quisimos mostrar, también es el río de Caronte, porque igual a la figura del barquero mítico, el sujeto en crisis es un vivo que viaja hacia la muerte y lleva las penas y la melancolía de un tiempo pasado, de una vida que ya no le pertenece. Es así que en las obras de Cruz Kronfly el sujeto en crisis inevitablemente debe emprender el viaje, no en busca de la aventura, sino para tratar de hallarse, y encontrar, así sea en el laberinto de la memoria, algo que le dé sentido a su existencia. Al final el viaje conduce al último misterio y la liberación de la existencia: la muerte. 


\section{Artificio literario en Fernando Cruz Kronfly}

Diríase, pues, volviendo a la reflexión de Madame de Staël, que estos jueces de hoy se interesan mucho más en la reconstrucción del crimen que en sus móviles o circunstancias.

Óscar Tacca. Las voces de la novela

El artificio literario es el recurso o los instrumentos escriturales que utiliza el autor para realizar su obra. Al momento de la creación, todo escritor emplea diversos métodos para entretejer la narrativa de la novela; se vale de mecanismos relevantes en la construcción de la historia. Nuestro propósito en este capítulo será explorar algunos de estos componentes, donde postulamos que son de vital importancia en Cruz Kronfly: la ensoñación y el erotismo de los cuerpos, la historia y la ficción a la que llamaremos ficción-histórica, y, finalmente, las categorías de autor, narrador y personaje que exploraremos basados en el texto de Óscar Tacca, Las voces de la novela, que a nuestro juicio están presentes y develan también el pensamiento racional de Fernando Cruz Kronfly. Queremos resaltar que pretendemos analizar e interpretar los elementos simbólicos y algunos estructurales que utiliza el escritor para elaborar su obra, el artificio que de una u otra forma sirve también para recrear la atmósfera y el contexto narrativo donde se encuentra inmerso el sujeto en crisis.

En la introducción al libro de cuentos: Artificios, Jorge Luis Borges, disertó sobre la naturaleza compleja de la elaboración de sus relatos. El autor argentino menciona sobre El Sur: "De El sur, que es acaso mi mejor cuento, bástame prevenir que es posible leerlo como directa narración de hechos novelescos y también de otro modo" (1956: 6). Y ese otro modo es donde en Borges se conjugan la filosofía y la literatura, pero también la historia y el relato detectivesco que permiten abrir el espectro narrativo y receptivo. En Cruz Kronfly trataremos de observar e interpretar esas distintas vertientes que son constantes y se entretejen en el discurso novelístico. Es importante mencionar que, como lo hemos 
realizado a lo largo de la presente investigación, nuestra apuesta es hermenéutica, sin embargo miraremos un poco el artificio desde el recurso narrativo y también, en algunos casos, desde su estructura. Nos apoyamos en el postulado de Gaston Bachelard en La poética de la ensoñación: "Método, método, ¿qué pretendes de mí? Sabes bien que he comido del fruto del inconsciente" (2004: 9). Observaremos entonces el artificio desde el símbolo y algunas convergencias entre historia, ficción y la pluralidad de voces del discurso novelístico para tratar de encontrar la apuesta escritural de Fernando Cruz Kronfly y tener una conciencia del artificio literario que de una u otra forma ambienta narrativamente al sujeto en crisis.

En La obra del sueño interpretaremos la ensoñación como recurso narrativo. Pensamos que a partir de allí se genera una constante de voces y sucesos. Para ello tomaremos como referente a Gaston Bachelard y su texto La poética de la ensoñación. Además resaltaremos en esta obra el erotismo de los cuerpos y su pulsión permanente. En La ceniza del Libertador, plantearemos el concepto de ficción-histórica apoyados en la obra de Hayden White en sus textos Metahistoria y El contenido de la forma. Por último en La caravana de Gardel matizaremos las categorías narrativas de autor, narrador y personaje y sus implicaciones en la voz novelística relacionándolas también con algunos ensayos de Cruz Kronfly, ya que el escritor ha reflexionado con gran lucidez sobre asuntos claves de su propio quehacer literario. Usaremos ciertos conceptos sobre los discursos y narradores de Óscar Tacca en Las voces de la novela, para hallar el hilo de Ariadna que se pierde en el laberinto novelesco. Pasemos entonces a observar, primero desde la hermenéutica y luego desde la estructura y las técnicas narrativas, es decir, desde los aspectos formales del discurso narrativo, el artificio literario que además es la herramienta simbólica y tangible, onírica y real de las obras de Fernando Cruz Kronfly.

\subsection{La ensoñación como recurso narrativo en La obra del sueño}

La obra del sueño, publicada en 1984, tiene como hilo conductor del relato la imaginación onírica. En esta novela la literatura recupera sus alas y vuela al mundo donde 
verdaderamente pertenece: al inconsciente. La ensoñación es un estado de la inconsciencia que posee un vislumbre de conciencia. No se está en el sueño totalmente sino que es un estado del alma donde el soñador crea imágenes oníricas a través de la realidad. Gaston Bachelard en La poética de la ensoñación, realiza una diferencia entre sueño y ensoñación. En el sueño estaría el consciente, es una parte de la psique más racional y lógica. En la ensoñación el inconsciente es dueño supremo de la imaginación, se rompe el método cartesiano y las imágenes adquieren su propia semanticidad simbólica. Así lo señala: "Gracias a la imaginación y a las sutilezas de la función de lo irreal, entramos en el mundo de la confianza, en el mundo del ser confiante, en el mundo mismo de la imaginación" (1998: 29). Y es en el mundo imaginante de Cruz Kronfly, que la narración nos sumerge en lo real pero también en la fantasía. El narrador, que en primer momento es la voz femenina de Genoveva, la mujer de Leopoldo, que comienza a relatar la historia novelesca se convierte en omnisciente y crea una atmósfera con todas las convenciones de un universo novelesco ordenado, luego describe sucesos irreales que son característicos del mundo onírico, del estado de ensoñación, o estado de anima como lo describió Jung para denominar una parte femenina de la psique. Carl G Jung, en El hombre y sus símbolos (1997) creó dos categorías anima y animus. Ambas complementan la psique del ser humano. La primera, el anima, es la parte femenina, la ensoñación poética. La segunda, el animus, es la parte masculina, el sueño que percibe en el consciente una realidad que debe ser ordenada. En la novela, Santiago, que vive en Dinamarca, quiere salvar a su hijo de un régimen militar, que al parecer desea asesinarlo y está al mando de un general llamado Pompilio. Santiago introduce a su hijo en un baúl y ordena a su criado Federico llevar a lomo de yegua el baúl hasta ponerlo a salvo. El fiel sirviente emprende la aventura pero en el camino es detenido por el régimen. Los militares comienzan a interrogarlo y Federico logra punzar una pata de la yegua para espantarla del lugar. Lo cómico y paradójico del suceso, es que el animal, llamado Polvo de los caminos, lleva unas gafas oscuras y fuma tabaco. Cruz Kronfly, narra una historia verosímil, y cuando describe que la yegua fuma y usa gafas, nos sorprende. En la obra se lee:

Polvo de los caminos, al galope y con sus anteojos oscuros descifrando la oscuridad, se perdía veloz por el antiguo camino que conducía a Jericó, la tierra de Abraham y de sus 
otros hermanos barbados cuyos bigotes entrapados en espuma de leche con coñac aún podía observarse en las fotografías familiares que colgaban de los muros de la casa de Santiago, su lejano bisnieto (1984: 110).

En el párrafo se puede observar el mundo onírico de Cruz Kronfly, que logra insertar en un relato común, elementos que rompen el orden de la historia narrativa y la atmósfera de lo real. En primer lugar, la yegua: Polvo de los caminos, usa gafas; y en segundo momento, el narrador dice que Santiago es bisnieto de Abraham, el personaje bíblico. Estas descripciones, entre otras que se encuentran en la novela, corresponden a la ensoñación, al estado inconsciente de una voz femenina que narra y sueña unos sucesos que se desvanecen en la memoria. Para ejemplificar nuestra conjetura leamos el anterior fragmento:

\footnotetext{
Pero, ahora nada importa. Nada que intente desmentir este extraño sosiego que me ha invadido después de la muerte de Leopoldo, interesa para mí. Por el contario, más allá de su brumosa memoria, en el paisaje de mis ojos sólo consiguen aparecer los lienzos de Salvador: relojes inmensos donde el tiempo ha muerto o dentro de cuyas cajas anónimas jamás existió (99).
}

Es así que la imaginación onírica construye su propio espacio y tiempo. El ensueño estructura bajo el inconsciente las imágenes literarias de la obra y guían el relato novelesco.

Un recurso relevante del artificio literario en la obra es el erotismo de los cuerpos. Es necesario mencionar que no tomamos ninguna teoría o conceptualización de la erotización del cuerpo. La planteamos en el sentido del artificio literario que emplea Cruz Kronfly para atraer y seducir al lector. El erotismo genera una pulsión que cautiva constantemente al lector. Genoveva, que en primer momento es la mujer que cuenta la historia, narra a su vez cómo sus hijas crecieron ayudadas por Mario, su fiel sirviente y amante. Quisiéramos mencionar que en la novela la polifonía que existe no une una sola voz, bifurca diferentes discursos y sentidos, o como plantea Bajtín, en Teoría y estética de la novela (1989:93), se utiliza el universo plurilingüístico de la palabra. La ensoñación de Genoveva está atada también a la erotización del cuerpo. Este elemento es importante porque el autor de la obra vuelve sobre él constantemente para entretejer el artificio literario en ensoñación y deseo. Veamos en la siguiente cita como Genoveva tiene ensoñaciones con sus hijas y recuerda sus vivencias con Mario: 
[...] lugar desde donde se lanzaban al vuelo de sus brazos abiertos, provistas con sus capas de polietileno, sus bolsas de sangre debajo de sus ojos ardientes, sus alas de madera de balso y sus colmillos colocados sobre el límite del labio inferior, a fin de que Mario las atrapara entre sus manos de felpa, como bien pudiese, mientras ponía a su disposición su cuello abierto que ellas chupaban con delirio, ávidamente, como si se tratara del líquido turbio de una fruta madura que se hubiese reventado contra el muro limpio de una cocina distinguida (1984:70).

También Genoveva se ve seducida en la ensoñación por el deseo y la erotización del cuerpo de su amado:

Con su mirada transparente parecía estar observando, en mi pubis, una billetera con dinero de altas denominaciones. Hasta que, pasado el primer momento de asombro, empezaba a contar el monto de aquella fortuna, al tiempo que con su lengua de felpa tocaba la campanilla, Ay!, aquella campana de dolor adorable, del dulce dolor sí, aquella diminuta campanilla de fibras de bronce y de vísceras que retumbaba en el templo de mi vientre (98).

Ensoñación y erotización del cuerpo son artificios literarios que sirven a Cruz Kronfly para generar posibilidades de sentido en la novela. La ensoñación permite las imágenes oníricas que empiezan con Genoveva, viajan al pasado y traen consigo la narratividad de la historia. Es un canal psíquico que permite al autor explorar los mundos de los personajes. La erotización, la cual resaltamos en las citas mencionadas, genera una pulsión permanente de los cuerpos, una atracción al deseo que se desarrolla y acompaña a la ensoñación a lo largo de la obra.

Quisiéramos mencionar que la erotización del cuerpo es también un artificio constante de Cruz Kronfly en otras obras. En Falleba, para citar un ejemplo, novela publicada por vez primera en 1980, se entretejen constantemente la erotización y la muerte. La obra cuenta la historia de unos personajes que se encuentran en decadencia, pero el cuerpo se convierte en un modo de exorcizar la muerte, de aplazarla. El cuerpo que no muere se convierte en un elemento de resucitación, le da característica de sujetos a los personajes de Falleba. Igual que la memoria (como se planteó en el segundo capítulo de esta investigación) es un arma contra las calamidades de la vejez, le recuerda a la muerte el milagro de existir. Una mujer llamada Mariana Valentina, que en la novela, es una anciana, tiene relaciones sexuales con Uldarico y Pánfilo casi hasta el final de la historia. En todo el trayecto, Cruz Kronfly crea en sus personajes el deseo del cuerpo, la necesidad sexual. Georges Bataille, en su texto sobre El erotismo $(2007: 8,19)$, plantea en la "Introducción" que cuando el hombre 
primitivo descubre en el coito la conciencia del rito del acto sexual, comprende que es un momento para escapar a la muerte y trasgredir todas las normas. Los personajes de Falleba giran alrededor de un erotismo sexual. El cuerpo se presenta como una excusa más para recordar o vivir. En la novela se lee:

Sonó entonces para Uldarico algo seco y grueso en la bitácora de su memoria. Estaba jugueteando apenas con las pompas del jabón, cuando sintió que Mariana Valentina resoplaba como una yegua tras el acrílico que separaba la ducha del lavamanos y el sanitario. Ven aquí ahora mismo, desconsiderada, no me quieres confesar tu verdadero nombre, a partir de este instante te llamaré putifar (2008:180).

Esta imagen erótica revive la memoria del personaje. Aunque de manera explícita no se mencionen relaciones sexuales; las palabras tienen una carga pragmática erótica que tienen la función de despertar un deseo corporal. Uldarico quiere pasar el acrílico que lo separa de Mariana Valentina, la escucha resoplar como una yegua, por tanto la llama con esmero, la quiere tener en ese instante. Es así que el erotismo, cargado de imágenes que incitan al deseo sexual, resucita el sujeto en crisis, combate las fatalidades de la existencia.

En La obra del sueño la ensoñación y el erotismo del cuerpo son artificios permanentes en Cruz Kronfly que develan simbólicamente como se entreteje la narratividad para crear también el sujeto en crisis.

Veamos ahora una categoría relevante del artificio de Cruz Kronfly en La ceniza del Libertador: la ficción-histórica y lo metaficcional que se mezcla en la obra para generar cierta complejidad donde gira el sujeto en crisis.

\subsection{Ficción-histórica en La ceniza del Libertador}

La historia y la ficción son relatos que utiliza el ser humano para simbolizar una parte de su cultura. En la historia se vuelve sobre hechos ocurridos. En la ficción se crean universos posibles que refractan la realidad. Aunque son mundos distantes, ambos están construidos sobre la imaginación. Hayden White en El contenido de la forma (1992) plantea que los 
historiadores, igual que los narradores de ficción beben de sucesos imaginarios, pues la historia, por más documentada y real que parezca, está construida sobre la subjetividad, sobre una visión particular del mundo. Al respecto, sobre la ficción y la realidad, el autor menciona:

Lo que se pondrá de manifiesto, según creo, es que la misma distinción entre acontecimientos reales e imaginarios, básica en las formulaciones modernas tanto de la historia como de la ficción, presupone una noción de realidad en la que se identifica «lo verdadero» con «lo real» sólo en la medida en que puede mostrarse que el texto de que se trate tenga el carácter de narratividad (22).

Es así, que la narratividad, la forma como se cuenta el relato, comienza a unir las distancias entre literatura e historia. La novela histórica o la ficción-histórica, como he querido mencionarlo, se construyen a partir de la narración, del modo como el escritor manipula el lenguaje y crea el artificio literario a partir de aquel mundo híbrido y proteiforme llamado historia.

En la novela la historia es un telón de fondo que ambienta las situaciones para que el autor utilice la técnica narrativa y el personaje viva. La historia resucita en la novela y logra develar la complejidad psicológica que pudieron haber enfrentado hombres ilustres en el paso del tiempo. Sobre el carácter de la narrativa el autor señala:

La narración es una forma de hablar tan universal como el propio lenguaje, y la narrativa es una modalidad de representación verbal aparentemente tan natural a la conciencia humana que sugerir su carácter problemático puede fácilmente aparecer algo pedante pero precisamente porque el modo de representación narrativo es tan natural a la conciencia humana, es tan claramente un aspecto del discurso hablado y común de cada día, que su uso en cualquier campo de estudio que aspire a la categoría de ciencia debe ser sospechoso (41).

La narrativa que menciona Hayden White, es la técnica de contar o el carácter escritural que utiliza el escritor para plasmar la obra. Quisiéramos mencionar que para White la historia misma está construida sobre diversos estilos, que según el autor en Metahistoria (2001: 9-10) son modos escriturales y persuasivos que emplea el historiador o el filósofo de la historia para argumentar un punto de vista o sustentar una idea respecto a la interpretación o hecho histórico.

En Metahistoria, el teórico realiza un recorrido sobre los historiadores y filósofos de la historia del siglo XIX, señalando en ellos unas características particulares, estas son: 
Dentro de cada una de esas diferentes estrategias identifico cuatro modos posibles de articulación por los cuales el historiador puede conseguir un efecto explicatorio de un tipo específico. Para la argumentación tenemos los modos de formismo, organicismo, mecanicismo y contextualismo; para la trama tenemos los arquetipos de la novela, la comedia, la tragedia y la sátira; y para la implicación ideológica tenemos las tácticas del anarquismo, el conservadurismo, el radicalismo y el liberalismo. Una combinación específica de modos forma lo que llamo "estilo" historiográfico de un historiador o filósofo de la historia en particular (2001:10).

Como podemos ver, para White la novela se encuentra en el entramado de la historia, por tanto, la ficción-histórica se construye en la narrativa, donde el personaje parece más importante que el suceso o el acontecimiento histórico. En este universo es donde Fernando Cruz Kronfly mezcla el artificio de La ceniza del Libertador. Es necesario señalar que al plantear la ficción-histórica queremos mencionar que aunque la historia del destierro de Bolívar fue real como se señala en La nueva historia de Colombia en el apartado "Presidentes de Colombia 1810-1990" (1989: 43, 51) lo que sufrió Simón Bolívar, sus delirios oníricos y sus sueños de héroe derrotado, son obviamente producto de creación de Cruz Kronfly, en este punto es donde la ficción-histórica cobra vida.

La ceniza del libertador, novela de ficción-histórica del escritor Fernando Cruz Kronfly, publicada en 1987, está construida sobre la realidad de sucesos (el viaje de destierro por el río Magdalena), sin embargo, su atractivo radica en aquello que la historia lineal no ha mencionado: lo que pudo haber sentido El Libertador Simón Bolívar, sus angustias, sus sueños, sus pesares, su melancolía en el último viaje por el río Magdalena, desde Honda hasta Santa Marta. La obra comienza por relatar la angustia que siente Bolívar a bordo del champán, una embarcación a vapor de dos pisos que fue utilizada por los navegantes de América del Sur para recorrer los ríos; Bolívar abrumado de pesares atraviesa el río Magdalena. El Libertador va acompañado de su sobrino Fernando, el coronel Santana, su sirviente José Palacios y un negro cocinero llamado Bernardino. Cruz Kronfly narra las visiones de Bolívar, sus recuerdos, la ansiedad de esperar un pasaporte y la libranza que le debe otorgar el gobierno por los servicios prestados a la patria. En la novela se respeta el suceso real del viaje, sin embargo, Cruz Kronfly cambia la embarcación por un champán de dos pisos para crear el universo narrativo y dimensionar el espacio novelesco. El escritor crea la ficción a partir de lo no dicho por los documentos históricos sobre la vida de 
Bolívar. Quisiéramos señalar que la investigación El ideal glorioso del héroe derrotado. Análisis lingüístico- literario de la ceniza del Libertador de Fernando Cruz Kronfly, muestra de forma estructural los hechos históricos y los inventados por Cruz Kronfly, nuestro objetivo es develar el artificio literario y plantear la ficción-histórica como una categoría del autor para crear el cosmos novelesco. Los autores de la investigación mencionan: "Y finalmente, mostraremos cómo Fernando Cruz Kronfly se sirve de la figura histórica de Simón Bolívar para contemporalizarlo y representar, a través de él, los universales que rigen la condición humana” (Posada, Gordillo y Castro, 1994:92). El carácter del personaje que trasciende el hecho histórico. Es necesario resaltar que, como lo quisimos mostrar en párrafos anteriores, la historia misma según Hayden White está hecha también de modo narrativo, por tanto: la historia y la ficción generan un proceso simbiótico en el discurso del autor. Esta idea, donde se conjuga la ficción y la historia en el discurso novelístico se desarrolla con claridad en el texto de Noé Jitrik: Historia e imaginación literaria. En el capítulo "Un acercamiento teórico a la noción de novela histórica” el autor utiliza la figura literaria del oxímoron para decir que en la novela histórica convergen la mentira y la verdad, la ficción y la realidad, la novela y la historia. Veamos:

Así, y con el objeto de comprender mejor la idea de ficción, vale la pena recordar por contraste que para formular un oxímoron -"un helado calor", en ejemplo elemental-, que sería engendrar algo no existente, como reunión de dos semas opuestos, se sigue un procedimiento determinado que da lugar a una imagen; sí, complementariamente, se produce una articulación que se designa como discurso poético (1995:13).

Y es en la unión de ideas contrarias, del oxímoron planteado por Jitrik, donde la ficciónhistórica en Cruz Kronfly se fusiona. En la misma Ceniza del Libertador la narración devela la conciencia del autor sobre la ficción histórica "Pues se trataba del retorno de cada quien, no a un lugar exacto sino a la bruma dentro de esa cosa espesa, imprevisible y traicionera que ellos conocían con el nombre de historia” (1987:16). Por tanto, la ficción y la historia convergen en el artificio escritural.

El entramado del relato, que se extiende prácticamente a lo largo de toda la novela, complejiza la disposición del espacio, un factor determinante en el seguimiento del desplazamiento que exige la travesía, extrayendo a la narración de un espacio físico 
histórico hasta situarlo en un lugar onírico. La dificultad del escenario se nutre todavía más mediante un flujo de conciencia proveniente del escritor quien se hace testigo del relato y a la vez su figura interpretante mediante el personaje de Uldarico Clavel. Es importante mencionar que este personaje aparece también en las novelas: Falleba (1980), El embarcadero de los incurables (1998), y La vida secreta de los perros infieles (2011). Así las cosas, cabe la posibilidad de que El Libertador no sea el único viajero o, en otras palabras, que la estética del viaje se reserve para ficcionar la vida de Bolívar. La arquitectura de esta obra en particular podría cobijar un viaje en segundo plano para un polizón.

Lo meta-ficcional, además de los poemas que entretejen la novela, es una particularidad fundamental para comprender la ficción histórica, o en otras palabras, la imaginación de la realidad. En la obra, Bolívar y su sobrino Fernando descubren que en la embarcación viaja un hombre que aún no se ha podido identificar. Cuando Bolívar ordena interrogarlo siempre desaparece. Cruz Kronfly se inserta en la obra para apreciar los sucesos desde el personaje de Uldarico Clavel, el moderno polizón que contrasta con la escena porque bebe de extraños tarros de cerveza y escribe todo el tiempo con esfero. En la novela se lee: "Usa lentes de aro negro, delgado, el espesor de los vidrios indica una miopía avanzada. Labios delgados, frescos, saludables, siempre húmedos rosados. Buen color en los pómulos, piel sana en lo visible, pestañas crespas, cejas gruesas..." (89). La cita describe al mismo autor y creador de la obra, elemento metaficcional, primero porque dos obras se escriben en una misma: afuera la de Cruz Kronfly, quien retrata el episodio histórico; adentro, la de Uldarico Clavel, quien describe el viaje desde sus propias observaciones al interior del vapor. Segundo, porque existe un juego con la perspectiva, un truco de espejos. Los hechos se observan desde dos puntos de vista: el del escritor, un ente alejado por el tiempo y la distancia que interpreta la materia histórica, y el de Uldarico, quien, producto de la misma ficción, aprecia directamente los sucesos. O bien, de otro modo, Uldarico Clavel es el espejo que le permite al escritor refractar su mirada para situarse a bordo del viaje. En las páginas finales, cuando El Libertador termina el viaje, es más claro el elemento metaficcional: 
Desde el puente, abandonado a otras manos, Su excelencia voltea a mirar hacia el vapor. Y observa, agarrado a la barandilla, al hombre del comedor. Levanta su mano, se despide de él. El hombre de los tarros de lata de la mesa de estribor sonríe, anota afanoso sus últimas cosas. En lo invisible de su vida Su Excelencia comprende que aquel hombre, que aquel testigo mudo lo ha escrito todo, lo contará todo algún día (330).

Bolívar observa al narrador Fernando Cruz Kronfly que describe su angustia. La ficción dentro de la ficción supera sus límites y trasciende no sólo en el mundo infinito de lo imaginario sino en la propia realidad, en la historia del hombre y su cultura.

El viaje de Bolívar no es el tema exclusivo de La ceniza del Libertador, el autor compone un personaje, un ego experimental que le sirve de vehículo psíquico para unirse a la travesía, y es que, como lo afirmó Milán Kundera en El arte de la novela: "El personaje no es un simulacro de ser viviente. Es un ser imaginario. Un ego experimental" (2004:45). Es decir que Bolívar cobra existencia real en la novela. Teniendo en cuenta el planteamiento de Kundera: "La novela es una meditación sobre la existencia a través de personajes imaginarios" (96) la travesía por el río Magdalena vista por los ojos de Uldarico Clavel es una meditación sobre la historia misma ya que, según Kundera: "No solo la circunstancia histórica debe crear una situación existencia nueva, sino que la Historia debe en sí misma, ser comprendida y analizada como situación existencial" (49). Por tanto, al hablar de personaje histórico en La ceniza del Libertador, podríamos decir, siguiendo la tesis de Kundera, que es en el universo narrativo donde finalmente se devela algo que trasciende la historia, y ese algo, es la literatura que muestra la complejidad humana.

La ficción-histórica muestra el discurso narrativo del autor. La narratividad, involucra una elección: "He sugerido, en síntesis, una afinidad electiva entre el acto de prefiguración del campo histórico y las estrategias explicativas utilizadas por el historiador en una obra determinada" (White, 2001:405). Esas estrategias que sugiere la cita es el modo como elige el historiador para contar el suceso. En el caso de La ceniza del Libertador nuestro novelista ha escogido crear un personaje que tiene de fondo un contexto histórico. La ficción-histórica entonces bebe de la historia para mostrar algo que va más allá del tiempo, ese algo, es la parte psíquica del hombre que tuvo que enfrentar circunstancias complejas que algunos libros lineales de la historia quizá no puedan develar. Resaltamos también el 
aspecto meta-ficcional como artificio narrativo en la novela porque complejiza su universo y nos lleva a pensar en las distintas vertientes del autor: una la vida de Bolívar, dos la mirada que tiene Uldarico Clavel y el mismo Cruz Kronfly sobre la historia donde finalmente navega el sujeto en crisis, quizá también bajo el artificio de la derrota y lo humano.

Interpretaremos entonces algunos elementos del artificio literario en La caravana de Gardel, que a nuestro juicio también son vitales para comprender cómo está elaborada la obra.

\subsection{Las voces del autor, narrador y personaje como artificios literarios en La caravana de Gardel}

La caravana de Gardel, publicada en 1998, es la última novela de las tres que en la presente investigación abordaremos. Su artificio es diferente a La obra del sueño (1984) y a La ceniza del Libertador (1987). En la primera existe un narrador en primera persona que a veces se alterna con la segunda y también se cambia a un narrador omnisciente. En la obra sobre Bolívar, el narrador aunque es omnisciente da el diálogo constante a los personajes y estos introducen su visión sobre el mundo. También se insertan un conjunto poemas en verso libre en la narración que buscan conjugarse en el mundo novelesco. Queremos recordar que en la introducción de la presente investigación: "Un escritor atemporal" realizamos un estudio sobre la conjugación entre poesía y narrativa en La ceniza del Libertador. Pretendemos entonces observar el autor, el narrador y el personaje en $\mathrm{La}$ caravana de Gardel, a la luz del texto de Óscar Tacca: Las voces de la novela, para matizar los diferentes discursos y lograr develar el artificio desde la óptica escritural. Vale la pena mencionar el ensayo de César Valencia Solanilla titulado: "El tango y la Modernidad en La caravana de Gardel de Fernando Cruz Kronfly”, en Revista de Ciencias Humanas $N^{\circ} 25$ donde el autor menciona: "El tango y el prostíbulo simbolizan el espacio de encuentro de la 
angustia y la desolación" (2000:52). Y efectivamente podemos ver a lo largo de $L a$ caravana de Gardel como el arriero Arturo Rendón encuentra en el prostíbulo un oasis de reposo momentáneo a sus penas, al peso del mundo que lo abruma. Describiremos entonces la trilogía de autor, narrador y personaje en el carácter ficcional y también el desdoblamiento del escritor que se bifurca y se desdobla al momento de la creación literaria para observar cómo influyen las voces en la creación del universo pulilinguístico de la palabra, que según Bajtín forman el discurso polifónico de la novela.

El autor, según Óscar Tacca en Las voces de la novela es aquel que incluye su manera de pensar en el relato. Su voz se devela para mostrar por medio de la narración su ideología acerca de la sociedad o la época del momento. Es necesario mencionar que Tacca bebe de Mijaíl Bajtín cuando el teórico ruso en "La palabra en la novela" dentro del texto Teoría y estética de la novela, menciona sobre el todo novelesco y el universo plurilingüístico de la palabra?: "Diversas formas literarias del lenguaje extraartístico del autor (razonamientos morales, filosóficos, científicos, declamaciones, retóricos descripciones etnográficas informes oficiales, etc.)" (1991:80). A partir de allí Óscar Tacca también dialoga con Bajtín. El teórico menciona:

La categoría de autor es la de escritor que pone todo su oficio, todo su pasado de información literaria y artística, todo su caudal de conocimiento e ideas (no sólo las que en vida sustenta) al servicio del sentido unitario de la obra que elabora. Esta entidad que llamamos 'autor' asoma muchas veces en el libro, detrás del narrador, no confiando enteramente en él, arreglando, componiendo, aclarando, acotando, completando" (1973:17).

Es así que el autor se separa del narrador para introducir un pensamiento o una idea que muestra una visión particular de la novela.

En el caso de La caravana de Gardel, es fácil identificar la voz del autor que se devela en el universo novelesco si sabemos que Fernando Cruz Kronfly, además de narrador, es ensayista y entre sus temas particulares se ocupa y preocupa de la literatura y su relación con la modernidad. En su texto La aldea encantada, el ensayista vallecaucano realiza un

$7 \quad$ Con esta expresión Bajtín plantea las diferentes voces que forman también visiones de mundo que se expresan alternadamente en la obra literaria. 
minucioso estudio sobre la obra cumbre de García Márquez: Cien años de soledad. En este texto argumentativo el autor postula que Macondo, igual que Latinoamérica está encantado y no ha sufrido lo que se atreve a llamar el desencanto de las imágenes del mundo, donde impera el pensamiento racional y lógico aristotélico. En Macondo tenemos creencias animistas y costumbres agoristas. Por nuestra cultura híbrida y proteiforme Colombia, igual que Latinoamérica, vive de creencias supersticiosas y se podría decir, postula el autor, que no hemos vivido el proyecto de la modernidad donde la ciencia y el método cartesiano hicieron carrera, convirtiendo el capital pensante del hombre en casi una máquina racional. Cruz Kronfly refiriéndose al proceso de modernización, plantea:

Pero, mientras este proceso de modernización se extendía por las ciudades de mayor contacto con los centros modernos, dinámicos y contagiosos, en nuestras aldeas alejadas continuaban vigentes el encantamiento del mundo, la mentalidad mágica y religiosa, los mitos y la hechicería, el poder de los augurios y la causalidad primaria no sometida a las normas y reglas que impone la ciencia" (2008:7-8).

Así pues, postula que el Macondo garciamarqueano es una forma de resistencia a la modernidad ilustrada y el pensamiento científico que ha hecho carrera en los países desarrollados. Sin embargo, La caravana de Gardel devela el sentimiento de abandono y fracaso del progreso de la modernidad. En la obra, se identifica la voz del autor que, como enunciamos en párrafos anteriores, es el pensamiento de Fernando Cruz Kronfly que se muestra en la novela. En la obra su voz permea la del narrador y la del personaje:

[...] Pero lo que más vino a contribuir a su trastorno fueron las letras de los tangos, los valses y las milongas. No sólo por lo que dichas decían acerca de la desesperanza en que había caído la existencia humana, llevada al límite de otro tipo de experiencia humana, llevada por esa otra sensibilidad y ese otro modo de encarar la vida que allí había. Y fue hasta la ventana y se asomó para ver por última vez la calle desierta" (1998:207).

La cita es clave para observar como por medio del narrador omnisciente se devela el pensamiento del autor, su manera de concebir el mundo. Y aunque en el Macondo garciamarqueano se vive en un mundo encantado, en la literatura de Cruz Kronfly ocurre lo contrario, no se cree en el relato del progreso moderno. En La sombrilla Planetaria el autor lo manifiesta: “[...] Dicho de otro modo, los metarrelatos han sido vistos, o han comenzado a ser vistos por primera vez como unos simples relatos más, con la consecuente pérdida o deterioro de su validez y legitimidad" (1994:30). Podríamos decir que el discurso entero 
articulado y elaborado en la novela, es también la voz del ensayista, del autor que se bifurca en distintas voces que es también lo que Bajtín llamó polifonía ${ }^{8}$.

El narrador en La caravana de Gardel cambia constantemente. Se sitúa a veces desde la tercera persona y desde la omnisciencia. Sin embargo, el narrador busca dar vida a los acontecimientos por medio de la óptica de los personajes. Para ser más precisos el narrador aunque está fuera de la historia logra que los lugares y sucesos vivan por sí mismos. Podríamos decir que el narrador se alterna desde la tercera persona y gana una vibración humana para crear una voz de los actos y situaciones. Sobre el modo de narrar Tacca refiere: "Si el narrador, en cambio, en lugar de acordarse de un punto de vista privilegiado para su información se ciñe a la que pueden tener los personajes; si renunciando a la mirada omnisciente opta por ver el mundo con los ojos de ellos, la narración gana en vibración humana" (77). Y pensamos que es esa vibración humana la que se exhibe en La caravana de Gardel. Veamos:

Entonces, al tomar por aquella vuelta, vieron en la distancia las farolas encendidas de una berlina hundida en la cuneta del costado izquierdo, sobre cuya cubierta ya sobrevolaban y daban saltos negras aves de rapiña. « Oh, Dios!», gimieron todos. Y no acababan de gemir cuando el conductor emparejó la berlina y vieron toda la sangre derramada en el polvo, como un tributo. Vieron cabezas de niños cortadas de cuajo, ensartadas en estacas. Vieron hombres a los cuales les habían sacado la lengua por el cuello, como una corbata de terciopelo" (60).

Podemos observar en la cita como el narrador logra que también los sucesos se perciban desde los personajes. La narración logra tener una vibración humana e impactante. El narrador entonces da vida a los sucesos que forman un eco que trasciende en la obra de Cruz Kronfly.

$8 \quad$ El concepto de polifonía es trabajado por Mijaíl Bajtín en Problemas de la poética de Dostoievski (1988) para referirse a la multiplicidad y dialogicidad de voces y visiones de mundo que se entretejen en la novela. En su capítulo "La palabra en Dostoievski" $(253,299)$ desarrolla el concepto de manera profunda encontrando ejemplos en el novelista ruso. 
El personaje tiene una voz propia que se filtra en el discurso del narrador. Existe un desdoblamiento de voces en la novela que se encuentra contenida en el discurso. Tacca sobre el personaje refiere: "Los personajes se han convertido paulatinamente en los canales fundamentales del caudal dramático. Más que el tema mismo de la novela han pasado a ser fuentes de información, juego de espejos, puestos de observación” (133). Así pues, la voz del personaje juega un rol importante pues este mismo es el individuo que piensa, dice y dialogiza. En La caravana de Gardel, el personaje principal Arturo Rendón muestra su visión de mundo no solo en el diálogo, el narrador consigue de forma indirecta hacer que Rendón muestre su manera de sentir. A pesar de que el diálogo en la obra es constante, es con una voz exterior que logramos interiorizar en la personalidad de Rendón. Veamos:

Arturo Rendón terminó de leer y se tumbó en el camastro. Completamente horizontal, con el sombrero puesto sobre sus ojos, lo mejor parecía ser por ahora la oscuridad. «Hay putas de putas» dijo y se sonrió, titubeando como había quedado en la encrucijada de varios sentimientos encontrados. «Cada mujer representa un nudo ciego en cada circunstancia», se dijo. $\mathrm{Y}$ en seguida bajó su sombrero hasta la altura del pecho y se puso a mirar el cielo de madera, donde había grietas negras y se veían manchas circulares de viejas goteras y filtraciones, como si quisiera descifrar allí el enigma de su vida (118).

En la cita podemos ver el pensamiento del arriero Arturo Rendón y con la voz del narrador que se filtra, como lo mencionamos anteriormente, su manera de sentir y percibir el mundo. Es así que la voz del personaje y la del narrador en La caravana de Gardel, pasan por un proceso alquímico que logran develar y desagarrar la psique del personaje. Queremos mencionar, como lo vimos en la cita, que los personajes en la novela de Cruz Kronfly, tienen un discurso estético. Rendón no es un hombre común y vulgar de la Colombia de mediados del siglo XX, su voz es particular, aunque proviene de una clase media y trabajadora, su voz y la del narrador logran exaltarlo como un personaje enigmático y llamativo.

Autor, narrador y personaje se mezclan en el discurso estético de la novela La caravana de Gardel para formar múltiples voces contenidas en la obra.

El artificio literario en Fernando Cruz Kronfly se presenta de diversas maneras. En La obra del sueño, la ensoñación y el mundo inconsciente es un recurso que permite en la novela crear diferentes atmósferas reales e imaginarias. En La ceniza del Libertador, el hecho 
histórico es solo un pretexto para develar el ser humano que se esconde tras la figura enaltecida del héroe Simón Bolívar. En La caravana de Gardel, las voces del autor, narrador y personaje, son matizadas y logran converger para mostrar el sentimiento del sujeto en crisis. Al término de este capítulo: "El artificio literario en Fernando Cruz Kronfly”, quisimos responder a una pregunta ¿Cuál es el recurso narrativo que utiliza el autor vallecaucano para crear sus obras?, hemos tratado de encontrar e interpretar algunos elementos que a nuestro juicio son relevantes en las obras estudiadas, y que de una u otra forma crean la atmósfera narrativa donde se halla inmerso el sujeto en crisis que hemos planteado a lo largo de nuestra investigación. 


\subsection{Conclusión}

El espíritu de la novela es el de la complejidad.

Milán Kundera. El arte de la novela

Nacido en Buga en 1940, bajo la sombra del gran auge de García Márquez, Fernando Cruz Kronfly logra crear una narrativa que explora la dimensión existencialista del hombre contemporáneo que se siente abrumado por el peso del mundo. La novelística del autor vallecaucano explora diversas vertientes. Entre ellas la poesía, la historia y la filosofía. Además de narrador y Doctor honoris causa por la Universidad del Valle, el autor ha escrito diversos ensayos que reflexionan sobre el pensamiento contemporáneo y la literatura. Sus novelas prolijas elaboradas con metáforas profundas y sentencias filosóficas, dan muestra de un esmero escritural y conciencia del lenguaje. Prueba de ello son las tres obras interpretadas a lo largo de la presente investigación, donde además de plantear el sujeto en crisis, mostramos las características particulares de sus obras, los símbolos que complejizan sus novelas, la multiplicidad de voces que entretejen el discurso y la estética de la palabra. En La obra del sueño (1984) está presente la reflexión filosófica por medio del autor, que como menciona Óscar Tacca en Las voces de la novela, el autor es el que piensa y su voz se filtra por medio del narrador y del personaje (1973:20). Quisiéramos resaltar la presente imagen, ya que no se agota en sí misma y muestra el pensamiento del filósofo francés Jean Paul Sartre a través de Leopoldo, un personaje relevante en La obra del sueño: "Pertenezco a la estirpe de los pensadores tristes, para quienes el mundo a duras penas tiene la consistencia de la mierda, tal como alguna vez lo alcanzó a insinuar mi inigualable maestro Jean Paul Sartre” (20). Lo anterior nos sirve para demostrar la conciencia del escritor sobre la filosofía existencial. Los personajes de Cruz Kronfly se enaltecen en el discurso, de allí que al leer sus novelas sintamos un halo de misterio hacia 
ellos que los vuelve llamativos y parecieran esconder un secreto que quiere ser develado. En La ceniza del Libertador (1987) Bolívar se humaniza, el autor utiliza el elemento de la ficción-histórica, para lograr descubrir el ser humano escondido en la figura del héroe. En La caravana de Gardel (1998) podemos ver con claridad el desarrollo escritural de Cruz Kronfly. En esta novela se muestra el sentimiento de abandono del hombre moderno. Creemos que la obra de Cruz Kronfly es una literatura ontológica, debido a la cantidad de símbolos y la complejidad narrativa que permite diversas interpretaciones. Nuestro objetivo en la presente investigación ha sido plantear el sujeto en crisis apoyados en la corriente del pensamiento de Martin Heidegger; sin embargo nos hemos dado a la tarea de interpretar ciertos elementos relevantes como la memoria y el espacio, el carácter simbólico del viaje, la ensoñación, y el artificio literario. Observaremos que el sujeto en crisis se plantea en una literatura compleja que busca refractar la psique del hombre y la época en que se encuentra inmerso.

La crisis del sujeto se produce en lo que podríamos denominar posmodernidad. La modernidad que en su principio se muestra sólida se desvanece en el aire; la metáfora citada por Marshall Berman en Todo lo sólido se desvanece en el aire (1991: 82), pertenece a una sentencia emitada por Carl Marx. El proyecto ilustrado del siglo XVIII y la industria que parecieron sacar para siempre al hombre del oscurantismo medieval y llevarlo a la felicidad, en parte fue una utopía. En nuestro primer capítulo nos apoyamos en sociólogos que plantean no el fracaso de la posmodernidad, pero sí un hombre con una desilusión y desencantado del mundo. Mostramos con Zygmunt Bauman en Modernidad líquida (2008) que algunos ideales como la colectividad y principios humanos de la Modernidad desaparecieron en la época actual. También observamos ese sentir de derrota y de vacío que plantea Marshall Berman en Todo lo sólido se desvanece en el aire: "[...] En este mundo, la estabilidad sólo puede significar entropía, muerte lenta, en tanto que nuestro sentido del progreso y el crecimiento es nuestro único medio de saber con seguridad que estamos vivos" (1991:90). Por tanto, pareciera ser que el ser humano cae en una suerte de desesperanza. En nuestra contextualización de la crisis del sujeto, la reflexión de John Grey en su texto El silencio de los animales. Sobre el progreso y otros mitos modernos 
(2013:60,72) fue clave, pues el sociólogo postula de forma directa que el siglo XX fue la muestra del fracaso humanístico del proyecto de la Modernidad según la cual los seres humanos olvidan sus diferencias y avanzan juntos hacia el desarrollo, no solo industrial, también fraternal e igualitario. Grey nos muestra con claridad como después de las guerras mundiales del siglo XX, la creencia del ser humano en la sociedad y el Estado fracasan, como no se puede volver al pensamiento teológico medieval, el hombre naufraga en la complejidad de la existencia. Es necesario en nuestra conclusión nombrar el texto de Sigmund Freud El malestar en la cultura (2010) donde el psicoanalista, como lo observamos en el primer capítulo, plantea que la cultura controla nuestros instintos agresivos y por tanto, el ser humano de una u otra forma es destructivo por naturaleza, solo que la sociedad le impone unas normas y ellas lo han llevado a construir la civilización. Lo que quisimos mostrar con Freud y los sociólogos mencionados es que la crisis del sujeto se produce por el fracaso ideal de la modernidad demostrado en el siglo XX donde la modernización con su tecnología se puso al servicio bélico. Con Freud pretendimos exponer esa parte destructiva del ser humano que quizá en la posmodernidad o contemporaneidad se ha desatado. Esto forma entonces la crisis del sujeto, la atmósfera para que surja el sujeto en crisis, en una sociedad que no le promete nada y donde intuye que no avanza hacia ninguna parte.

El sujeto en crisis lo planteamos tomando como referencia una categoría del pensamiento heideggeriano en su obra cumbre El ser y el tiempo. En su texto, el filósofo define al ser como ser ahí, despojándolo de su carácter de Yo dominador dueño de la naturaleza, por tanto, el sujeto se desprende de su carga racional, de su absolutismo controlador. No tiene una consciencia de sí mismo, en otras palabras el sujeto necesita saber que existe, tener una relación que lo haga saber de su Yo. Postulamos entonces el sujeto en crisis, que evade la realidad y no tiene la conciencia del Yo que lo hace existir, sino que vive atado al recuerdo, a la memoria. En las novelas estudiadas en la presente investigación La obra del sueño (1984) La ceniza del libertador (1987) y La caravana de Gardel (1998) el sujeto en crisis está representado por los personajes de Leopoldo, Simón Bolívar y el arriero Arturo Rendón. Leopoldo un filósofo joven tiene visiones de la catástrofe del mundo que generará 
el ser humano, vive sumido en sueños ilusorios y escapa a la realidad, es el único de los tres personajes citados que podría saber lo que genera la crisis. Bolívar debido a su enfermedad tiene visiones constantes de su pasado, de sus angustias y pesares. Arturo Rendón solo vive para recordar tiempos que fueron significativos cuando transportó el cuerpo de Gardel por las montañas de Colombia. Por tanto, los personajes de Cruz Kronfly en las novelas mencionadas escapan al presente, no tienen una conciencia del Yo, parece ser que vivieran en otros tiempos. Es importante resaltar que aunque los tres personajes son sujetos en crisis, esta se manifiesta de manera distinta en las novelas, lo cierto es que los personajes huyen de sí mismos debido no solo al fracaso del progreso de la Modernidad, quizá también a su existencia misma, a la crisis que enfrentan.

En nuestro segundo capítulo: "La caída y la memoria del sujeto en crisis", quisimos interpretar dos aspectos relevantes que están presentes de forma simbólica en las novelas estudiadas. El primero es la caída. El segundo, la memoria. Nos apoyamos en la teoría de Gilbert Durand desarrollada en su obra Las estructuras antropológicas de lo imaginario (2004: 116, 405) para interpretar las imágenes presentes desde una hermenéutica de sentido, donde no hay una forma unívoca de significación. El sujeto en crisis cae simbólicamente en las novelas estudiadas. En La obra del sueño Leopoldo es desterrado de su casa. Su padre lo envía a un lugar lejano para salvarlo de la guerra. Sin embargo, el personaje es desprendido del cariño maternal y del hogar. Bolívar, en La ceniza del Libertador, cae de la gloria, el héroe es desterrado y parece sumergirse en el abismo de la nada. En La caravana de Gardel, el arriero Arturo Rendón empezó su caída desde que entregó el cuerpo del cantautor argentino Carlos Gardel. Por tanto, los tres personajes caen en el abismo de la existencia. Queremos resaltar que en nuestro capítulo mostramos también que la caída se muestra abismal y termina los días del ser humano. De igual forma simboliza también el tiempo, como lo ejemplificamos basados en la teoría de Durand, que devora la existencia e infunde miedo. El sujeto en crisis desciende hasta el punto de no tener una conciencia de sí mismo y al final el tiempo lo consume.

En nuestro segundo capítulo también interpretamos el papel de la memoria, que en las obras logra eufemizar las desdichas de los personajes. Aunque en la caída vimos la 
incertidumbre de la existencia del sujeto en crisis; la memoria, que demostramos bajo la luz del fenomenólogo Gilbert Durand, crea un espacio donde el tiempo no transcurre y por un momento la caída se transforma en descenso, la irremediable desdicha y sensación de abandono es aplazada mientras los personajes escarban imágenes pasadas en el laberinto de sus memorias. Es necesario mencionar que el tiempo en la caída genera una angustia. Por el contrario, en el espacio eufémico donde los personajes de las novelas de Cruz Kronfly exorcizan sus penurias, este parece detenerse. Observamos entonces en nuestro segundo capítulo que primero el sujeto en crisis cae y el tiempo parece anunciarle el fin de los días, sin embargo, la memoria logra que los personajes en el caso de Genoveva, la cual también muestra características del sujeto en crisis en La obra del sueño, Bolívar en La ceniza del Libertador y Arturo Rendón en La caravana de Gardel, creen un espacio fuera la realidad. Espacio que crea la memoria para aliviar las penas de la caída y refugiar, así sea por poco tiempo, la angustia del sujeto en crisis.

En nuestro tercer capítulo: "El viaje hacia la muerte del sujeto en crisis y el agua de Caronte" interpretamos el significado de la travesía que recorren los personajes de Cruz Kronfly en las novelas estudiadas. Observamos y tomamos como referencia el texto del ensayista vallecaucano Fabio Martínez: El viajero y la memoria. Un ensayo sobre la Literatura de viaje en Colombia (2005) donde la tesis principal del autor es plantear la relación del viaje y la memoria. Postulamos que en las novelas de Cruz Kronfly los personajes no solo realizan un recorrido en el laberinto de su memoria, sino que además el sujeto en crisis parte porque no se halla y no se reconoce. El viaje en La obra del sueño, La ceniza del Libertador y La caravana de Gardel, es un intento de autoafirmación del Yo, del no ser ahí heideggeriano que trata de encontrarse. Leopoldo parte sin esperanza, Bolívar es desterrado y parece que purgara sus penas, pues a donde arriba las personas le gritan ofensas, Arturo Rendón hace un viaje para tratar de reconocer no solo las prendas u objetos de Gardel, sino para encontrarse a sí mismo. El viaje entonces del sujeto en crisis culmina en la muerte. Los tres personajes simbólicamente navegan en la barca del viajero mítico Caronte que transportaba las almas de los muertos por el río Estigia. De igual forma el 
sujeto en crisis, que también viaja en el pasado, es conducido a la muerte sobre el agua de la melancolía.

El agua de la melancolía acompaña a los personajes derrotados de Cruz Kronfly. El sujeto en crisis navega en la desesperanza y esta a su vez introduce un halo poético, un isomorfismo a la imagen simbólica donde encontramos una relación también con el mito de Narciso que es seducido por su propia imagen hacia la muerte. Gaston Bachelard resalta un aspecto clave en El agua y los sueños "Desaparecer en el agua profunda o desaparecer en un horizonte lejano, asociarse a la profundidad o a la infinitud; tal es el destino humano que busca su imagen en el destino del agua" (2003:25). Y es ese destino el que encontramos en las novelas estudiadas. Los personajes en crisis navegan hacia su fatalidad y a la vez recuerdan con tristeza los rostros y los sucesos de otros tiempos. En La obra del sueño Genoveva navega en la memoria; en La ceniza del Libertador la imagen del agua se presenta de forma literal, Bolívar lleva la proa sobre el río Magdalena y con él sus penurias y una enfermedad que devela el ser humano del héroe; en La caravana de Gardel para interpretar la figura del agua que refracta al sujeto en crisis, tomamos como referencia la teoría de Gilbert Duran descrita en Las estructuras antropológicas de lo imaginario, donde el autor plantea: "[...] el agua, al mismo tiempo que bebida, fue el primer espejo estancado y oscuro" (2004:99). El espejo, como lo demostramos en nuestro capítulo, es utilizado en diferentes ocasiones por Arturo Rendón, que lo mira constantemente para tratar de encontrar algo que no volverá. Es así que nuestro sujeto en crisis navega sobre el agua de la melancolía. Es necesario mencionar que le dimos el adjetivo de melancolía porque los personajes se sienten abrumados por sus desdichas y el peso del mundo. El agua entonces se presenta simbólicamente en la memoria y el viaje lleva consigo a los personajes como si fueran las almas de los muertos que conducía el barquero infernal Caronte hacia la irremediable suerte del no ser, de perderse y tratar de encontrarse solo en el pasado, a la muerte donde termina el recorrido del sujeto en crisis.

En el artificio literario, tema de nuestro cuarto y último capítulo, quisimos responder a la pregunta ¿Qué elementos simbólicos, históricos y narrativos utiliza Fernando Cruz Kronfly para crear sus obras? A nuestro juicio encontramos algunos aspectos relevantes, sin 
embargo, queremos dejar claro que existen otros de igual o mayor importancia, solo que ya han sido estudiados por distintos investigadores o quizá nuestra lectura particular no logra detectarlos. En La obra del sueño, interpretamos y planteamos: la ensoñación como recurso narrativo, nos apoyamos también, como lo hemos hecho a lo largo de nuestra investigación en Gaston Bachelard, que en su texto La poética de la ensoñación $(1998: 9,48)$ plantea un estado de inconsciencia que tiene un vislumbre de conciencia, a ese estado el fenomenólogo denomina ensoñación y lo relaciona con el ánima que es una parte femenina de la psique. En ese estado se produce la poética y se sueñan las palabras. Planteamos entonces que la ensoñación es un recurso que utiliza Cruz Kronfly de una manera magistral en La obra del sueño. Desde el principio de la novela Genoveva, una mujer cae en el estado de anima y comienza la narración. Constantemente el narrador vuelve sobre ella para continuar a través de sus ojos una historia que no tiene un carácter lineal, y donde, como lo demostramos con ejemplos precisos, ocurren sucesos fantásticos como la yegua Polvo de los Caminos que toma té y fuma tabaco o la descendencia del personaje bíblico Abraham. Es así que los sucesos fantásticos, propios también del mundo onírico, son introducidos en el universo discursivo de la novela y están permitidos porque la ensoñación es el recurso narrativo del autor.

En La ceniza del Libertador planteamos el concepto de ficción-histórica apoyados en el teórico de la historia Hayden White y sus obras: El contenido de la forma $(1992: 12,43)$ y Metahistoria (2001: 10,63). En la primera el autor propone el concepto de narratividad y de manera general llega a la conclusión que tanto la historia como la ficción son construidas de manera narrativa, por tanto, ambas beben de la misma fuente escritural. No hay en los dos discursos una diferencia tajante, en otras palabras, el hecho histórico y el discurso ficcional vienen de la subjetividad e imaginación del escritor. En Metahistoria, el autor realiza un recorrido por los filósofos de la historia como Hegel, Ranke, Nietzsche y algunos textos del siglo XIX, para también plantear que en su esencia provienen de la ficción que estaría en la conciencia del modo de narrar, ya que el autor finalmente no puede retroceder en los años y verificar si aquello que nos cuentan sobre el suceso histórico es fidedigno, por ello utilizan figuras como la ironía y la metáfora. A partir de las conjeturas propuestas por 
White encontramos entonces En la ceniza del Libertador de Cruz Kronfly que Bolívar y su travesía por el río Magdalena se podrían considerar como un suceso que perteneció a una situación histórica del país cuando Simón Bolívar fue desterrado de La gran Colombia, sin embargo, el suceso en sí es irrelevante y superfluo. Lo que verdaderamente importa en el universo de sentido de La ceniza del Libertador, son las angustias, los pesares, la melancolía y la muerte de aquel que libertó cinco repúblicas. Es así, que la historia en Cruz Kronfly se utiliza como un telón para develar el conflicto existencial del sujeto en crisis, siguiendo la tesis de Kundera en El arte de la novela "El novelista no es ni un historiador ni un profeta: es un explorador de la existencia” (2009:36). Y esa existencia de Bolívar es la que encontramos sólo en la novela, no en el texto histórico, pues allí Bolívar no sería humano. Es necesario mencionar que al referirnos a la ficción-histórica, pretendimos plantear en el escritor vallecaucano la mezcla de la imaginación y la realidad, que finalmente es el artificio mayor en La ceniza del Libertador.

La caravana de Gardel, de las tres novelas estudiadas, es la que quizá muestra con mayor claridad el pensamiento del autor vallecaucano sobre la Modernidad y el tiempo en que se encuentra inmerso. Realizamos una diferencia esencial entre narrador, personaje y autor apoyados en el teórico Óscar Tacca y su texto: Las voces de la novela $(1973: 11,137)$ para lograr matizar las diferencias pero también la pluralidad de voces que se entretejen en el discurso novelístico del escritor vallecaucano ${ }^{9}$. Es necesario mencionar que resaltamos en La caravana de Gardel que la voz del autor se filtra por la del narrador omnisciente y la del personaje para mostrar una visión de mundo sobre la Modernidad, que en el caso de la novela es el desamparo y abandono que siente el arriero Arturo Rendón y su compañera sentimental la Leona, como si el hombre estuviera a la deriva y fuera hacia ninguna parte. Esto nos lleva a pensar en los ensayos de Fernando Cruz Kronfly como La aldea encantada (2008:7-8) donde el autor muestra su visión de mundo sobre la Modernidad y plantea que el Macondo garciamarqueano ha logrado resistir al capital pensante moderno, sin embargo, su

9 Queremos resaltar que la teoría de Las voces de la novela de Óscar Tacca dialoga con el universo plurilingüístico de la palabra expuesto por Mijaíl Bajtín en: Problemas de la poética de Dostoievski (1998). 
obra narrativa muestra el náufrago a la deriva del hombre contemporáneo, en ella el sujeto en crisis se siente perdido en el mundo.

El sujeto en crisis tiene unas características particulares que se definen claramente en las novelas: La obra del sueño, La ceniza del Libertador y La caravana de Gardel, las hemos resaltado a lo largo de nuestra investigación; las resumiremos brevemente para matizar las categorías que son fundamentales para comprender nuestra interpretación y planteamiento:

1- La crisis del sujeto se genera debido al fracaso de la Modernidad ${ }^{10}$, que aunque en nuestra tradición latinoamericana y precisamente en Colombia no tuvo los grandes hitos históricos, podríamos pensar que en la literatura de Fernando Cruz Kronfly el personaje se empieza a mostrar abrumado por el peso del mundo, como si la sociedad no le prometiera nada, es por ello que quiere escapar incluso de sí mismo.

2- El sujeto en crisis no tiene una conciencia del presente y avade el sí mismo, no es un Yo dominador, es un ser ahí, un ente que tiene la posibilidad de ser si se pregunta por sí mismo. Aunque posee presencia física, su existir se encuentra atado al recuerdo, en otras palabras es conducido por la inercia de la vida, sin embargo, se encuentra en imágenes pasadas en recuerdos que lo encadenan a otro tiempo y a otro espacio.

3- La memoria y el espacio son elementos psíquicos del sujeto en crisis. La memoria porque se convierte en su refugio, es la única alternativa que tiene el sujeto en crisis para existir así sea fuera del presente. El espacio, que se constituye con imágenes y personajes que fueron importantes para el sujeto en crisis y que logran olvidar sus desdichas y eufemizar por momentos las calamidades de su existencia. Es importante mencionar que la memoria y el espacio tienen también la función de exorcizar el tiempo y aplazar las desdichas que enfrenta el sujeto en crisis.

10 Es necesario mencionar que en nuestra investigación nos apoyamos en sociólogos como Marshall Berman y su texto: Todo lo sólido se desvanece en el aire (1991), Sygmunt Bauman en Modernidad Líquida (2008) John Gray El silencio de los animales. Sobre el progreso y otros mitos modernos (2013), donde los autores coinciden en que el proyecto común que tuvo la Modernidad en sus inicios de generar una sociedad que valorara más la otredad y pudiera avanzar hacia una humanidad más equitativa y más justa en realidad fue una utopía. 
4- El sujeto en crisis siempre emprende un viaje y al final muere. Emprende el viaje simbólico hacia la memoria y hacia sí mismo. Recorre en los laberintos olvidados de su vida pasada una imagen de sí mismo que lo haga existir y encontrar su identidad. La muerte, como lo comprobamos en nuestra investigación, lo libra definitivamente de la carga existencial que la memoria solo lograba aplazar, la irremediable fatalidad de su existencia termina con la muerte que hace que descanse también de sí mismo.

Al término de nuestra investigación, queremos culminar diciendo que Fernando Cruz Kronfly, al menos en las novelas estudiadas, muestra una literatura compleja en imágenes y símbolos. Su prosa prolija da cuenta de la elaboración de sentencias y la mezcla entre poesía y narrativa, como en el caso claro de La ceniza del Libertador. El artificio de la historia se utiliza de manera magistral para develar la complejidad de la existencia. Hemos planteado la categoría del sujeto en crisis porque los personajes elaborados permiten una interpretación simbólica y filosófica. La literatura de Cruz Kronfly es ontológica porque explora la dimensión humana. Su lenguaje esmerado y cuidadoso, nos lleva a pensar que es uno de los autores contemporáneos que escapan no solo a la literatura de siliconas y culos artificiales, sino a ese estigma donde los personajes solo dicen madrazos, y no existe una sola metáfora o símil capaz de conmover al lector, como si la literatura perdiera esa estética de la palabra que la hizo tan grande con autores universales. Quizá entonces, en Fernando Cruz Kronfly, autor vallecaucano, renazca esa literatura que logra ir más allá de las historias televisivas y del marketing. 


\section{Bibliografía}

\section{Fuentes primarias}

Cruz Kronfly, Fernando (1984). La obra del sueño. Medellín: Oveja negra. Cruz Kronfly, Fernando (1987). La ceniza del libertador. Bogotá: Planeta. Cruz Kronfly, Fernando (1999). La caravana de Gardel. Bogotá: Planeta.

\section{Fuentes teóricas}

Bajtín, Mijaíl (1988). Problemas de la poética de Dostoievski. Ciudad de México: Fondo de Cultura Económica.

Bajtín, Mijaíl (1989). Teoría y estética de la novela. Madrid: Tauros.

Bachelard, Gaston (2003). El agua y los sueños. Ciudad de México: Fondo de Cultura Económica.

Bachelard, Gaston (2004). La poética de la ensoñación. Ciudad de México, México: Fondo de Cultura Económica.

Berman, Marshall (1988). Todo lo sólido se desvanece en el aire. Bogotá: Siglo XXI editores.

Bauman, Zygmunt (2002). Modernidad líquida. Ciudad de Buenos Aires:

Cassirer, Ernst (2006). Antropología filosófica. Ciudad de México: Fondo de Cultura Económica.

Durand, Gilbert (2004). Las Estructuras Antropológicas de lo Imaginario. Ciudad de México:

Fondo de Cultura Económica.

Freud, Sigmund (1993). El malestar en la cultura. Buenos Aires: Hyspamérica.

Gray, Jhon (2013). El silencio de los animales. Sobre el progreso y otros mitos modernos. Madrid: Editorial Sexto Piso.

Heidegger, Martin (1993). El ser y el tiempo. Bogotá: Fondo de cultura económica.

Jitrik, Noé (1995). Historia e imaginación literaria. Buenos Aires: Editorial Biblos.

Jung, Carl (2004). El hombre y sus símbolos. Ciudad de México: Fondo de Cultura Económica.

Kundera, Milan (1994). El arte de la novela. Barcelona: Tusquets.

Martínez, Fabio (2005). El viajero y la memoria. Cali: Editorial Universidad del Valle.

Tacca, Óscar (1973). Las voces de la novela. Madrid: Gredos

Weber, Max (2012). La ética protestante y el "espíritu” del capitalismo. Madrid: Alianza Editorial.

White, Hayden (1992). El contenido de la forma. Barcelona: Tauros.

White, Hayden (2001). Metahistoria. La imaginación histórica en la Europa del siglo XIX. México: Fondo de Cultura Económica.

\section{Fuentes secundarias}

Arismendi Posada, Ignacio (1989). "Presidentes de Colombia 1810-1990”. Nueva historia de Colombia. Bogotá: Planeta.

Abirached, Robert (2011). La crisis del personaje en el teatro moderno. Madrid: ADE.

Auerbach, Erich (1976). Mimesis. Ciudad de México: Fondo de Cultura Económica.

Borges, Jorge Luis (1956). Artificios. Madrid: Alianza Editorial.

Bloom, Harol (2001). Shakespeare: la invención de lo humano. Bogotá: Norma

Bachelard, Gaston (2004). La poética del espacio. Ciudad de México, México: Fondo de Cultura Económica.

Cros, Edmon (1992). Ideología y genética textual. Madrid: Cupsa.

Cruz Kronfly, Fernando (1992). La ceremonia de la soledad. Santafé de Bogotá: Planeta.

Cruz Kronfly, Fernando (1994). La sombrilla planetaria. Santafé de Bogotá: Planeta. 
Cruz Kronfly, Fernando (1995). "La última noche volátil de Ricaurte” en Gaceta Risaralda. Pereira (3): 3-16.

Cruz Kronfly, Fernando (1998). La tierra que atardece. Santafé de Bogotá: Ariel.

Cruz Kronfly, Fernando (1998). Amapolas al vapor. Santiago de Cali: Editorial Universidad del Valle.

Cruz Kronfly, Fernando (2002). Abendland, Medellín, Fondo Editorial EAFIT.

Cruz Kronfly, Fernando (2007). La derrota de la luz: ensayos sobre modernidad, contemporaneidad y cultura. Cali: Universidad del Valle.

Cruz Kronfly, Fernando (2006). Falleba. Ibagué: Pijao Editores

Cruz Kronfly, Fernando (2008). "La aldea encantada". Colección Bitácora, Universidad Industrial de Santander (6): 1-26.

Cruz Kronfly, Fernando (2009). "Desarrollo cultural, modernidad e identidad en Santiago de Cali" en Visión Cali 2036.Cali (1): 142-164. .

Cruz Kronfly, Fernando (2011). La vida secreta de los perros infieles. Madrid: La mirada Malva.

Cruz Kronfly, Fernando (2012). Destierro. Medellín: Sílaba.

Cervantes, Miguel (2008). Don quijote de la mancha. Lima: Punto de lectura.

Dostoievski, Fedor (1967). Crimen y castigo. Barcelona: Juventud.

Fuenmayor, José Félix (2007). "La muerte en la calle" en Antología de cuentos colombianos. Bogotá: Alfagura.

Fuentes, Carlos (1993). Geografía de la novela. Madrid: Alfaguara.

Jung, Carl Gustav (1993). Símbolos de transformación. Barcelona: Paidós

Kundera, Milan (1984). La insoportable levedad del ser. Barcelona: Tusquets Editores.

Kremer, Harold (1992). Antología del cuento vallecaucano. Cali: Editorial Universidad del Valle.

Quesada, Fernando (1998). La filosofía política en perspectiva. Barcelona: Anthropos

Rulfo, Juan (19839). El llano en llamas. Bogotá: Editorial La Oveja Negra

Shakespeare, William (1999) Hamlet. Barcelona: Folio.

Sartre, Jean Paul (1993). El ser y la nada. Barcelona: Altaya

Vargas, Edwin Alonso (2013). Una lectura filosófica al personaje anómalo de la nueva narrativa colombiana (Tesis de maestría). Universidad Tecnológica de Pereira.

Vernant, Jean-Pierre (2001). El individuo, la muerte y el amor en la antigua Grecia. Barcelona: Paidós.

\section{Sobre el autor}

Ayala Poveda, F. (1981). "Fernando Cruz Kronfly de perfil y de frente". En Novelistas colombianos contemporáneos. Bogotá. Universidad Central, (1): 75 - 100.

Bastidas Pérez, Rodrigo (2011). "La caravana de los incurables Posmodernidad en Fernando Cruz Kronfly” en Hojas Universitarias. Bogotá (64): 23-33.

Consuegra, Jorge. (1992). "La nueva novela de Fernando cruz Kronfly. El poder es el escenario de los mediocres y siempre termina en manos de los mediocres” en Revista Universidad de Antioquía. Medellín, (61): 116 - 119.

Carsé, Lioju (2003). "Diálogo Con Fernando Cruz Kronfly" en La Palabra. Cali (12):6.

Cruz Kronfly Fernando (1995). "El triunfo de la razón: otro mito moderno" en Gaceta Risaralda Cultural. Pereira (3): 20-25.

García, Aguilar (2002). "Deseo y soledad en cuatro novelas de Fernando Cruz Kronfly". Revista de cultura. (28): 1-5

Giraldo, Luz Mary (1997). "La cuentística de Fernando Cruz Kronfly: Fundación de un mundo" en Literatura: teoría, historia, crítica. (1): 138-149. 
Herrera Muñoz, Marcos Fabián (2010). "Las sombras de la gloria. Entrevista a Fernando Cruz Kronfly”. Espéculo. Revista de estudios literarios (46). Consultado el 03 de enero de 2015, en http://www.ucm.es/info/especulo/numero46/sombrasgl.html

Henao, Darío (2012). "Falleba o los límites de la memoria: La ciudad como representación”. Cali. Centro virtual Jorge Isaacs. Consultado el 15 de septiembre de 2013. Recuperado de http://cvisaacs.univalle.edu.co

Henao, Darío (2012). "Un novelista del hondo abismo del oficio de escribir". Cali. Centro virtual Jorge Isaacs. Consultado el 28 de septiembre de 2013. Recuperado de http://cvisaacs.univalle.edu.co

Jiménez Calderón, Oscar Eduardo. (2014). Historia y ficción en la ceniza del libertador. Tesis de Maestría en Literatura, Universidad del valle, Santiago de Cali.

Jurado Valencia, Fabio. (1995). "Los imaginarios en la narrativa de Fernando Cruz Kronfly" en Fin de siglo: narrativa colombiana. Santiago de Cali. CEJA, (1): 183 - 198.

Martínez, Fabio; Urriago, Fernando (2008). Cali-grafías La ciudad literaria. Cali: Programa Editorial Universidad del Valle.

Martínez, Fabio (2015). Entrevista al maestro Fernando Cruz Kronfly. Cali. Recuperado de http://ntc-documentos.blogspot.com.es/2015_01_03_archive.html

Moreno Parrado, Lucila. Colorado Marín Paula (2011). Fernando Cruz Kronfly y la

caravana de la modernidad en Colombia (Tesis de maestría en literatura). Universidad Javeriana. Recuperado de http://hdl.handle.net/10554/1664.

Mena Cobo, Luz Ángela (1983). Análisis psicoanalítico de Falleba. (Tesis de pregrado en Literatura), Universidad del valle, Santiago de Cali.

Ortiz, Omar (1998). "Fernando Cruz Kronfly. La literatura como reflexión” en Magazín Dominical. Bogotá (797):8-10.

Pineda, Álvaro (2005). Estudios críticos sobre la novela Colombiana. Medellín: Universidad EAFIT

Posada, Gordillo y Castro (1994). El ideal glorioso del héroe derrotado. Análisis lingüísticoliterario de La ceniza del Libertador de Fernando Cruz Kronfly (Tesis de pregrado). Instituto Caro y Cuervo. Recuperado de biblioteca.caroycuervo.gov.co/cgi-bin/koha/0p

Restrepo, María del pilar (2000). "La temporalidad en la obra de Fernando Cruz Kronfly" en Estudios de literatura colombiana. Medellín (7): 99- 102.

Ruíz Gómez Darío (2007) Literatura, historia, circunstancia. Cali: Editorial Universidad del Valle.

Urriago Benítez, Hernando (2006). "Fernando Cruz Kronfly, el ensayo y la vocación de reflexionar" en Poligramas. Cali (25): 109-131.

Urriago Benítez, Hernando (2002). La poética del ensayo en la sombrilla planetaria. Tesis de pregrado en literatura, Universidad del valle, Santiago de Cali.

Valencia Solanilla, César 81996). La escala invertida. Pereira: Fondo Mixto de Cultura del Tolima.

Valencia Solanilla, César (1997). "La sombrilla planetaria de Fernando Cruz Kronfly" en Papel Salmón. Pereira (6): 258-259.

Valencia Solanilla, César (2000). "El tango y la modernidad en la caravana de Gardel de Fernando Cruz Kronfly" en Revista de Ciencias humanas. Pereira. Universidad Tecnológica de Pereira, (25): 49-56.

Vargas Franco, Alfonso (2004). "La desesperanza y la muerte en la novela La ceniza del libertador de Fernando Cruz Kronfly” en Poligramas, (21): 171- 184. 